\title{
Multiscale, multimedia and multi-element geochemical mapping of the State of Paraná, Brazil
}

\section{Otavio Augusto Boni Licht}

Instituto de Terras, Cartografia e Geologia do Paraná - ITCG

Desembargador Motta St., 3384

Curitiba, State of Paraná, Brazil

Current Address

Programa de Pós-Graduação em Geologia

Universidade Federal do Paraná

Universidade Federal do Pa
Centro Politécnico - UFPR

Av. Cel. Francisco H dos Santos, 100

81530-000 - Jardim das Américas,

Curitiba, State of Paraná, Brazil

otavio.licht@gmail.com

\begin{abstract}
RESUMO
O Paraná foi o primeiro estado brasileiro que executou levantamentos geoquímicos sistemáticos em escala regional, complementados por alguns em escala localizada na cidade de Umuarama e de sua capital Curitiba. Nesses levantamentos foram coletadas amostras de água e sedimentos fluviais e solo, sendo aplicadas técnicas analíticas multielementares com aberturas totais e/ou parciais. Os resultados obtidos permitiram a elaboração de mapas geoquímicos para a visualização da distribuição dos elementos no território paranaense, estabelecer associações de grupos de elementos característicos do ambiente natural e as alterações impostas pela ação do homem. Os resultados obtidos por esse programa de mapeamento geoquímico contribuem para o conhecimento do subsolo, exploração mineral, diagnósticos ambientais e identificação de áreas de risco à saúde humana.
\end{abstract}

Palavras-chave: mapeamento geoquímico, geoquímica multipropósito, exploração mineral, diagnósticos ambientais, geologia médica

\section{ABSTRACT}

The State of Paraná was the first Brazilian state to perform systematic geochemical surveys on a regional scale, complemented by some more detailed ones, focusing the town of Umuarama and its capital Curitiba as well. In these surveys, stream water samples were collected, together with stream sediments and soil samples, multi-element analyses have been applied with total and/or partial digestion. The results obtained allowed the elaboration of geochemical maps to visualize the spatial distribution of the elements in the territory of Paraná, to establish associations of groups of elements indicating natural environment characteristics and the changes imposed by the human activities as well. The multipurpose applications of this geochemical mapping program contribute to geology knowledge, mineral exploration, environmental diagnostics and identification of areas of risk to human health.

Keywords: geochemical mapping, multi-purpose geochemistry, mineral exploration, environmental diagnosis, medical geology

\section{INTRODUCTION}

Geochemical maps were used for the first time by White (1922 apud Sergeev 1941) to define and restrict the prospecting area for $\mathrm{Cu}$ mineralization, receiving the name of cuprometric survey. Since then, the sampling and analysis of rock, soil, sediment, and river water samples in various geographical regions on the planet has been broadly used for mineral prospecting, but it has also been increasingly used for other purposes such as geological mapping, agricultural fertility, environmental diagnosis and identification of health risk areas. In addition to the geochemical mapping of such large territories, small-scale maps have been used as a solid base in the urban zoning and the identification of contaminated areas in few urban areas during this period, like Moscow, for example.

At the end of the 20th century, the International Union of Geological Sciences IUGS, joined with the United Nations Educational, Scientific and 
Cultural Organization UNESCO initiated within the International Geological Correlation Programme framework, the IGCP-259 International Geochemical Mapping (Darnley et al. 1995). As outlined in this project's final report, several protocols for the planning, collection, preparation, and analysis of samples were established. They were designed as a standard guide to be followed by interested countries so that in a medium-term perspective, it is possible to build a homogeneous database for the preparation of planetary geochemical maps. Given the broad acceptance by the scientific community, the project was renewed as IGCP-360 Global Geochemical Baselines (Smith et al. 2012, Smith et al. this Special Issue). These protocols were used as a guideline for the design and implementation of the State of Paraná geochemical mapping projects, which will be examined below. The Geochemical Survey of Brazil, which is being performed since 2009 by the Brazil Geological Survey - CPRM-SGB, also complies with those international recommendations. To date, this national geochemical mapping project has already gathered a total of 13,906 stream water samples, 18,771 stream sediment samples, 4,625 soil samples (B horizon) and 2,536 public supply water samples, covering an area of 3,268,500 $\mathrm{km}^{2}$, which means $38 \%$ of the Brazilian territory (Fernanda Cunha, personal communication, 2017).

\subsection{A BRIEF GEOGRAPHIC AND GEOLOGICAL DESCRIPTION OF THE STATE OF PARANÁ}

The State of Paraná is located in southern Brazil and occupies an area of $199,575 \mathrm{~km}^{2}$ (ITCF 1987). It limits to the North with the State of São Paulo, with the Atlantic Ocean to the East, the State of Santa Catarina in the South, with the Republic of Argentina to the Southwest, to the West with the Republic of Paraguay and the State of Mato Grosso do Sul (Figures 1 and 2). The

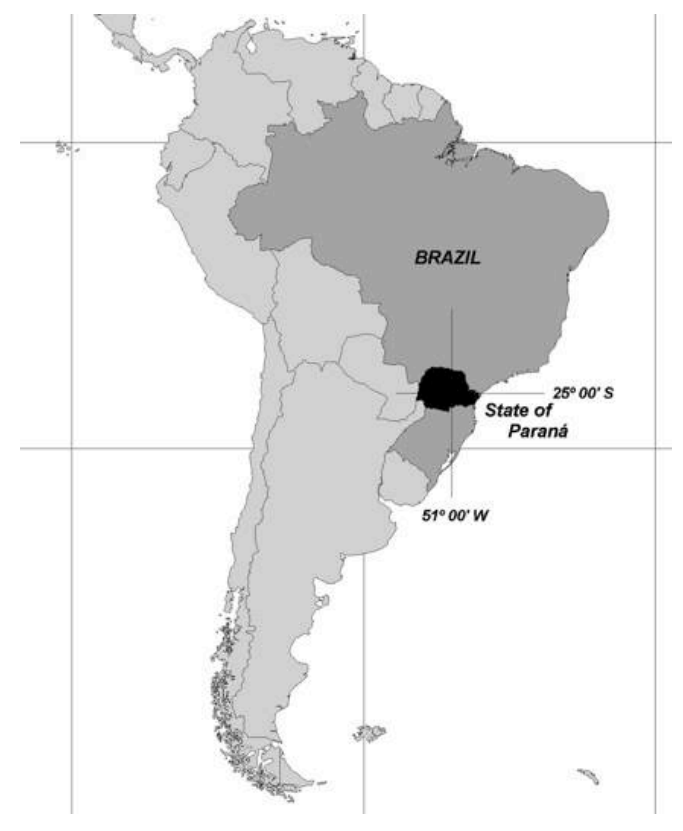

Figure 1

The location of the State of Paraná in South America. climate is subtropical, with temperatures ranging from $0{ }^{\circ} \mathrm{C}$ to $36^{\circ} \mathrm{C}$. The rainiest area, with an average of $4,000 \mathrm{~mm} / \mathrm{year}$, is located on the eastern slope of the Serra do Mar; to the North, precipitation decrease with averages between 1,200 and $1,300 \mathrm{~mm} /$ year. These characteristics allow us to identify the following Köppen climate types: Cfa, Cfb, Af (IAPAR 1994).

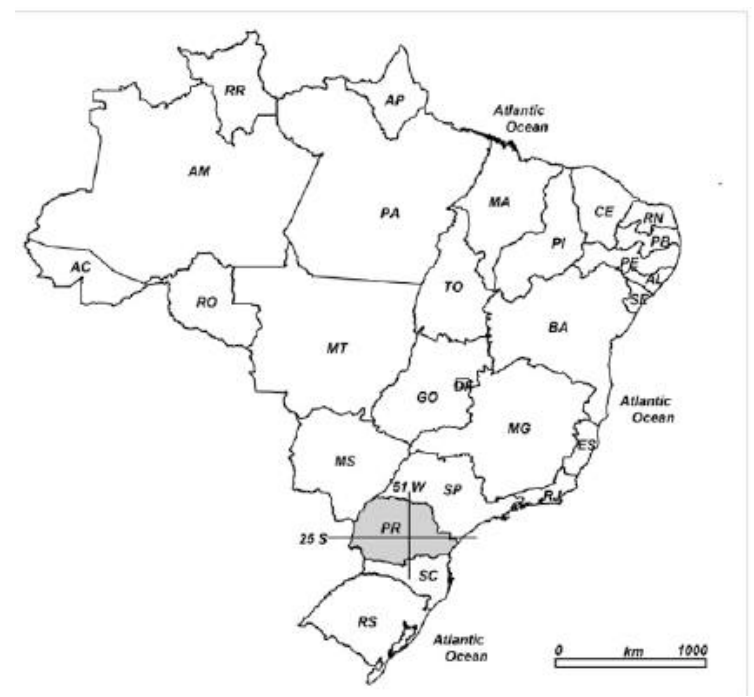

Figure 2

The State of Paraná (PR) and other Brazilian States. 
The State of Paraná contains a dense and persistent hydrographic network, being the Serra do Mar the main watershed, separating the Coastal Plain basins, from those belonging to other geographic compartments. Most rivers flow towards the Paraná river valley, except for the basins of the Ribeira river and those of the Coastal Plain which drain to the Guaratuba and Paranaguá bays, or directly to the Atlantic Ocean. Until the late 19th century, the territory of Paraná was covered by lush vegetation which housed a very rich and diversified fauna. Currently, only $5 \%$ of the original forest cover remains, as the economy of the State of Paraná is mainly based on agroindustry, being the largest Brazilian grain

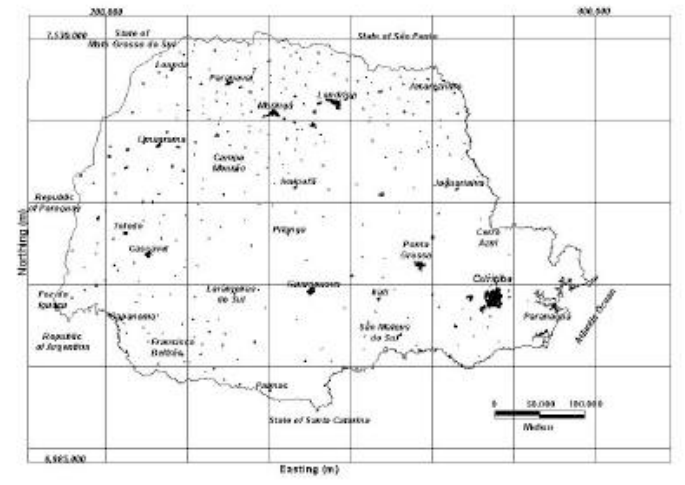

Figure 3

Selected cities of the State of Paraná.

From East to West, the State of Paraná is characterized by successive compartments, namely Coastal Plain, First, Second and Third plateaus (Maack 1968) (Figure 4). Geology (Figure 5) and soils of these compartments are briefly described below, following MINEROPAR (1987) and Larach et al. (1984), respectively.

The Coastal Plain consists of Holocene mangroves, terraces and sandy strips along the coastline and beaches, being the soils mainly hydromorphic and podzol. The transition from the Coastal Plain to the First Plateau is made by the Serra do Mar, an abrupt mountain range whose altitudes reach 1,922 meters above sea level, and composed by the Serra Negra Complex (Archaean) and Pre-Setuva Complex (Proterozoic), mainly granulite, norite, migmatite, gneiss, magnetite-quartzite, Mg marble, schist, $\mathrm{Mg}$ amphibolite, metabasics, meta-pyroxenite, granite and granodiorite. The soils are dominantly cambisols and lithosols. There are some $\mathrm{Au}$ deposits in quartz-sulfide complex veins, as well as black sands deposits mostly composed of ilmenite and rutile arranged along old coastlines. producer and responsible for $10 \%$ of the national dairy production, the third largest producer of poultry, eggs, and pigs. Also, the food industries, machinery, wood, paper, and textiles play an important role. Its mineral industry is the main national talc producer and the third of ornamental stones and also noted in red ceramic, limestone, dolomite, bituminous shale, mineral water and materials for immediate use in construction. The population of the capital Curitiba along with that of many neighboring cities exceeds $3.2 \mathrm{M}$ inhabitants. Other major cities are Londrina $(553,900)$, Maringá $(430,000)$, Ponta Grossa $(341,000)$, Cascavel $(317,000)$ and Foz do Iguaçu $(263,000)$ (Figure 3).

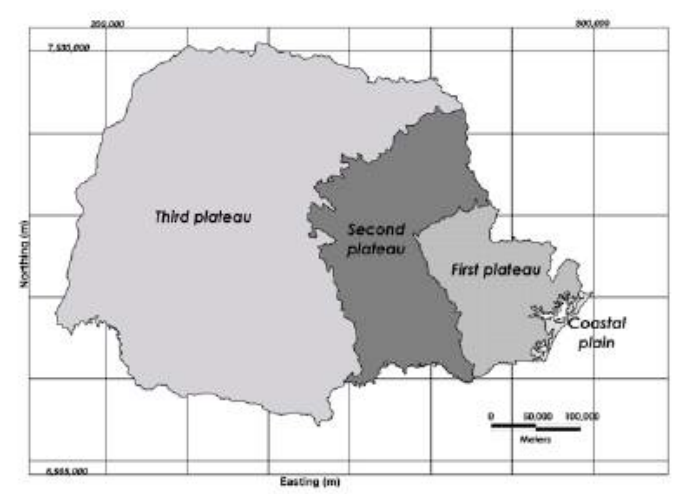

Figure 4

The geomorphological compartments of the State of Paraná (Maack 1968).

The First Plateau is represented by (1) Setuva Group (lower Proterozoic) - migmatite and gneiss, schist, calc-schist and marble, quartzite and metabasic rocks; (2) Açungui Group (upper Proterozoic) - meta conglomerate, metasandstone, quartzite, phyllite, metamorphic limestone or dolostone, metabasic rocks and amphibolite and metamorphosed basic tuff and lava; (3) Brasiliano cycle - large anatectic bodies of alkali granite, granodiorite, monzonite and alaskite; (4) Camarinha Formation (Palaeozoic) - siltstone, sandstone and conglomerate; (5) Guaratubinha Formation and Castro Group (Paleozoic) siltstone, sandstone and conglomerate, andesite, rhyolitic domes and flows, ignimbrite, ash tuff and pyroclastics, breccias and volcanic agglomerates. Curitiba's basin is filled by layers and lenses of gravel, sand, silt, and clay of the Guabirotuba Formation (Tertiary). Mineral occurrences include $\mathrm{Au}$ in quartz-sulfide veins, sulfides of $\mathrm{Pb}-\mathrm{Zn}-\mathrm{Cu}$ on meta-carbonates, $\mathrm{Sn}-\mathrm{W}$ in greisen, talc in dolomite and fluorite in carbonates, granite, and alkaline rocks and carbonatite. There is an underground gold mine operating near the town of Campo Largo. 

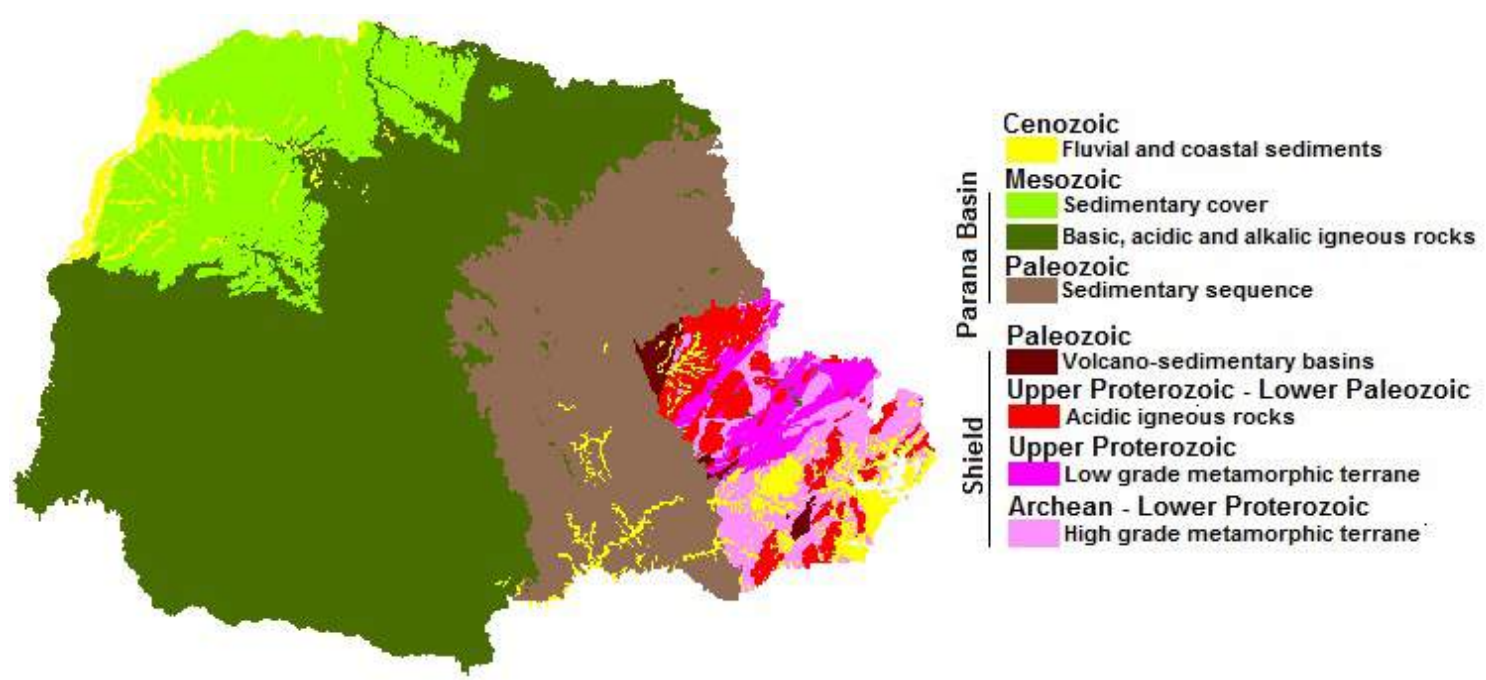

Simplified geologic map of the State of Parana (modif. MINEROPAR 2009)

The Second Plateau gently dips to the West and is established on the thick Paleozoic sedimentary sequence, which composes the Paraná Basin. Its lowermost unit is represented by the Paraná Group (Devonian) composed of conglomerates, sandstones, siltstones, and shales, covered by the Itararé Group (Lower Permian), composed of thick layers of sandstone, shale, siltstones, rhythmite and diamictite, with rare coal seams. This is covered by the Guatá Group (Middle Permian), composed of sandstones, siltstone, shales, calcareous layers with carbonaceous shales and coal seams, followed by the Passa Dois Group (Upper Permian), composed of sandstones, shales, siltstone, argillite, limestone, layers rich in organic matter with $U$ and oil-bearing shales. The soils are shallow and with low fertility, with the prevalence of the lithosol, cambisol, and podzol, developed from the sedimentary rocks.

\section{MATERIALS AND METHODS}

The geochemical surveys of the State of Paraná were planned and executed under the auspices of the Geochemical Information System of the State of Paraná - SIGEP, which was established by the State Decree $N^{\circ}$ 4389-13/12/94. In 1996, SIGEP was accepted by the VI Meeting of the Brazil-China Technical-scientific Cooperation Joint Committee, giving the necessary support for technical training as well as the production of geochemical data in the reference laboratories of the Institute of Geophysical and Geochemical Exploration, located in the city of Langfang, People's Republic
The geology of the Third Plateau includes the São Bento Group. This unit contains conglomeratic sandstone, sandstone and siltstone lenses of the Pirambóia (Upper Jurassic) and Botucatu Formations (Eo-Cretaceous). They are covered by basic (basalt and andesi-basalt and associated volcaniclastics) and acidic flows (dacite, rhyodacite, and rhyolite) belonging to the Serra Geral Group (Eo-Cretaceous). These volcanic rocks contain mineralizations of amethyst and zeolites filling geodes and $\mathrm{Cu}-\mathrm{Au}-$ $\mathrm{Ag}$ occurrences of minor economic significance. The Caiuá and Bauru groups (Upper Cretaceous) are found in the northwest portion of the Third Plateau and consist of conglomerates, sandstones, siltstone and argillite. Exception made for those of the extreme northwest, the Third Plateau's soils are very fertile, since derived from basic volcanic rocks, and comprise thick red latosols, structured terra rossa, and red/yellow podzols.

of China. This geochemical mapping program involves and was supported by many state and federal institutions in the form of technical cooperation, either focused on the recovery of old geochemical databases or the production of new geochemical data sets. To better evaluate the sequence and the complexity of the work comprised by the State of Paraná geochemical mapping, the main components of this long-term research program, which lasted from 1995 until 2005 and involved dozens of researchers affiliated to research institutions from Brazil and abroad, will be described in detail. 


\subsection{INTEGRATION OF PREVIOUS MINERAL EXPLORATION PROJECTS}

During the 1970's and the first half of the 1980 's, several mineral exploration companies have performed exploration projects in the Paraná Shield (First Plateau) and have generated a vast amount of geochemical data, which contributed to the discovery of $\mathrm{F}, \mathrm{Au}, \mathrm{Cu}-\mathrm{Pb}-\mathrm{Zn}$ and $\mathrm{Sn}-\mathrm{W}$ mineral deposits and showings. Assuming the role of the Geological Survey of the State of Paraná, in 1995 MINEROPAR decided to retrieve these various geochemical exploration datasets and test their potential to produce reliable maps, showing the correlation between geochemical contents with geological units. The data were retrieved from digital files produced by 22 geochemical mineral exploration surveys carried out in the Paraná Shield, in varying scales from regional reconnaissance to anomaly verification, what reflects on sample density $\left(\right.$ sample $\left./ \mathrm{km}^{2}\right)$. The average sampling density adopted by these surveys was ca. 2.9 sample $/ \mathrm{km}^{2}$ but, it ranges from 1.6 to 178.9 samples $/ \mathrm{km}^{2}$ depending on the scale and the type of survey (Table 1). The sampling and analytical work were executed in a nine-year period (from 1976 until 1985); each company (MINEROPAR, PETROMISA, and
CPRM) used their own field teams, supervisors and geochemical laboratories.

The samples were dried, sieved and the fraction $<80 \#(<0.177 \mathrm{~mm})$ was then sent to geochemical laboratories for analysis, using the analytical procedures listed in Table 1 . In the surveys performed by CPRM, the samples were sieved in the collection site with a nylon mesh, whereas the MINEROPAR and PETROMISA samples were sieved in the laboratory. Eleven geochemical surveys of MINEROPAR with F and $\mathrm{Au}$ contents in sediment samples and pan concentrates were also integrated. Even though it is expected that such different samples would not produce comparable results, the geochemical maps showed surprising correlation with the local and regional geological background. The samples were analyzed by three different geochemical laboratories (LAMIN-CPRM, Geolab-GEOSOL, and TECPAR). Although each lab used internal standards for the analytical quality control, there was no cross-calibration between them and for the production of integrated geochemical maps the data were not submitted to any leveling or standardization. Despite these limitations, the geo-

Table 1 - Summary of analytical procedures for integrated stream sediment surveys. Analytical procedures applied in the < 80\# fraction: (1) aqua regia digestion atomic absorption; (2) $\mathrm{HNO}_{3}$ concentrate, hot, digestion/atomic absorption; (3) colorimetry; (4) hydride generation/atomic absorption; (-) not analyzed. The location of each survey is shown in Figure 6. After Licht \& Tarvainen (1996).

\begin{tabular}{|c|c|c|c|c|c|c|c|c|c|c|}
\hline \multirow{2}{*}{ Company } & \multirow{2}{*}{ Survey } & \multirow{2}{*}{$\begin{array}{c}\text { Samples } \\
/ / \mathbf{k m}^{2}\end{array}$} & \multicolumn{8}{|c|}{ Elements / analytical procedures } \\
\hline & & & $\mathrm{Cu}$ & $\mathbf{P b}$ & $\mathbf{Z n}$ & $\mathbf{N i}$ & Co & $\mathbf{F e}$ & Mn & As \\
\hline \multirow{19}{*}{ Mineropar } & 1. Paraiso & 178.9 & (1) & (1) & - & - & - & - & - & - \\
\hline & 2. Marquês de Abrantes & 123.1 & - & (1) & - & - & - & - & - & - \\
\hline & 3. Nagib Silva & 81.5 & (1) & (1) & (1) & - & (1) & - & - & - \\
\hline & 4. Tigre-Betara-Açungui & 9.7 & (1) & (1) & (1) & (1) & (1) & (1) & (1) & (4) \\
\hline & 5. Formação Agua Clara & 5.3 & (1) & (1) & (1) & (1) & (1) & (1) & (1) & (1) \\
\hline & 6. Caçador Jacui & 22.1 & (1) & (1) & (1) & (1) & (1) & (1) & (1) & (1) \\
\hline & 7. Barra do Itapirapuã & 12.2 & (1) & (1) & (1) & (1) & (1) & (1) & (1) & (4) \\
\hline & 8. São Silvestre & 22.9 & (1) & (1) & (1) & (1) & (1) & (1) & (1) & (1) \\
\hline & 9. Volta Grande & 29.0 & (1) & (1) & (1) & - & - & (1) & (1) & (4) \\
\hline & 10. Castro & 47.5 & (1) & (1) & (1) & (1) & (1) & (1) & (1) & (4) \\
\hline & 11. Antinha & 18.0 & (1) & (1) & (1) & (1) & (1) & (1) & (1) & (4) \\
\hline & 12. Capivari-Pardo & 31.1 & (1) & (1) & (1) & (1) & (1) & (1) & (1) & (4) \\
\hline & 13. Canha-Carumbé & 10.7 & - & (1) & - & - & - & - & - & - \\
\hline & 14. Guaratubinha & 39.1 & (1) & (1) & (1) & (1) & (1) & (1) & (1) & (4) \\
\hline & 15. Anhangava & 10.7 & (1) & (1) & (1) & (1) & (1) & (1) & (1) & (4) \\
\hline & 16. Capivara & 21.4 & (1) & (1) & (1) & - & - & (1) & (1) & - \\
\hline & 17. Santana & 58.8 & (1) & (1) & (1) & - & - & (1) & (1) & - \\
\hline & 18. Granitos & 1.6 & (1) & (1) & (1) & - & (1) & - & - & (4) \\
\hline & 19. Capivari-Pardo & 7.8 & (1) & (1) & (1) & (1) & (1) & (1) & (1) & (4) \\
\hline \multirow{3}{*}{$\begin{array}{l}\text { DNPM- } \\
\text { CPRM }\end{array}$} & 20. Vale do Ribeira & 3.3 & (2) & (2) & (2) & (2) & (2) & (2) & (2) & - \\
\hline & 21. Guaratubinha-Piên & 4.2 & (2) & (2) & (2) & (2) & (2) & - & - & (3) \\
\hline & 22. Castro-Piraí & 7.7 & (2) & (2) & (2) & (2) & (2) & (2) & (2) & (3) \\
\hline \multirow[b]{2}{*}{ Petromisa } & 23. Furnas-Ponta Grossa & & (2) & (1) & (1) & (1) & (1) & (1) & (1) & - \\
\hline & $\begin{array}{l}\text { 24. Furnas-Ponta Grossa } \\
\text { (fill in) }\end{array}$ & 2.9 & (2) & (2) & (2) & - & - & - & - & (2) \\
\hline \multicolumn{2}{|c|}{$\begin{array}{c}\text { Data in the } \\
\text { integrated database }\end{array}$} & $\begin{array}{c}\text { Average } \\
2.9\end{array}$ & 14,746 & 15,267 & 14,694 & 9,117 & 9,026 & 7,831 & 7,876 & 7,351 \\
\hline
\end{tabular}


chemical maps show distinctive distribution patterns, which may be correlated with geological features from the Paraná Shield. Also, this is mainly due to the use of a uniform preparation technique (fraction $<80 \#$ ) in all surveys, similar extraction procedures (aqua regia or hot and concentrated $\mathrm{HNO}_{3}$ ) and the excellence of internal quality control procedures of the three laboratories

The $\mathrm{F}$ contents were obtained by analyzing 2,270 samples of stream sediments $(<80 \#)$ and pan concentrates as presented in Table 2 .
The geochemical surveys conducted by state companies and agencies (MINEROPAR, DNPMCPRM, and PETROMISA), mainly cover the northern half as well as some small regions of the southern part of the Paraná Shield (Figure 6). The field books and geochemical data were already stored in digital files, what facilitate the task of data recovery and integration (section 2.9. Geochemical mapping techniques). Due to confidentiality issues, it was not possible to recover and integrate geochemical data produced by private companies.

Table 2 - Summary of integrated F stream sediment and pan concentrate surveys. All samples were analysed by alkali fusion + specific ion electrode. After Licht \& Tarvainen (1996)

\begin{tabular}{ccc}
\hline Company & Survey & Type of sample \\
\hline & Paraíso & Pan concentrate \\
Cantagalo & Pan concentrate \\
Nagib Silva & Stream sediment \\
& Barra do Itapirapuã & Stream sediment \\
Volta Grande & Pan concentrate \\
& Volta Grande & Stream sediment \\
& Capivari-Pardo (fill-in) & Pan concentrate \\
& Canha-Carumbé & Pan concentrate \\
& Anhangava & Pan concentrate \\
& Granitos & Pan concentrate \\
& Capivari Pardo & Pan concentrate \\
\hline
\end{tabular}

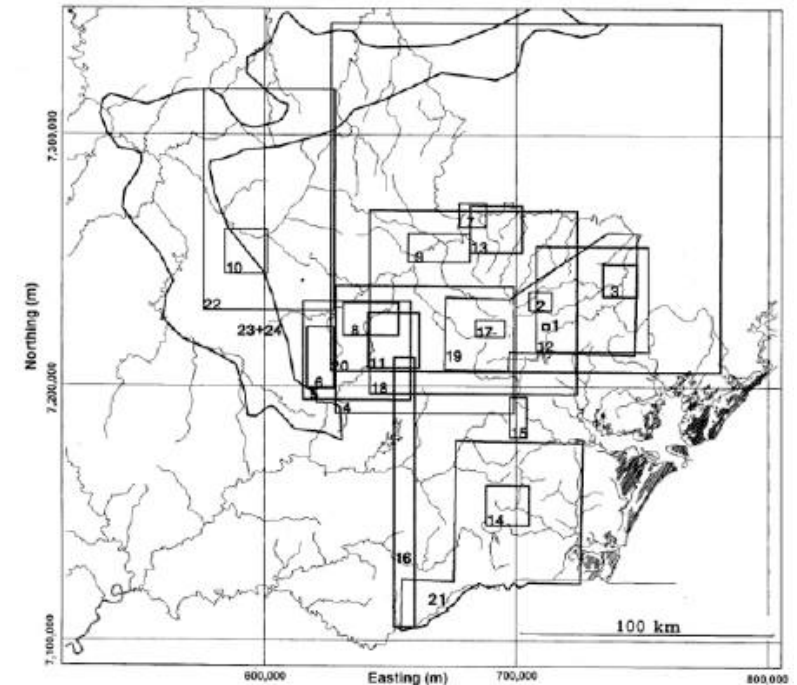

Figure 6

The contour of the 22 geochemical surveys whose compose the final integrated database (see Table 1) (Licht \& Tarvainen,

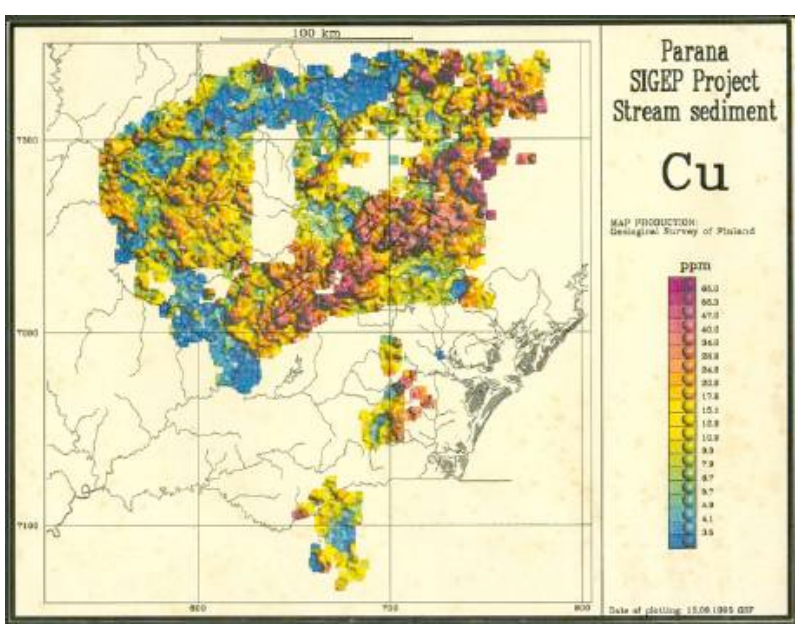

Figure 7

Geochemical surface is showing $\mathrm{Cu}$ distribution in stream sediments from 14,746 sampling sites (see Table 1) (Licht \& Tarvainen 1996). 


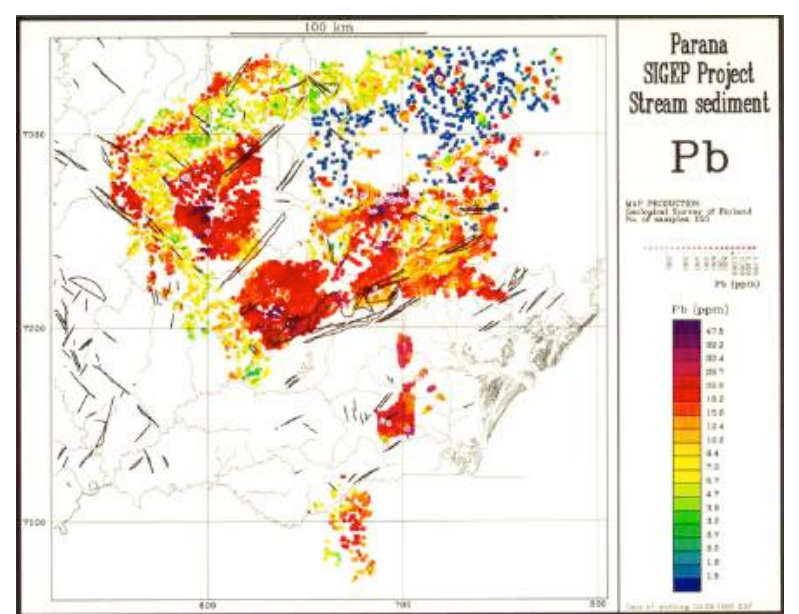

Figure 8 Geochemical map showing $\mathrm{Pb}$ distribution in stream sediments from 15,267 sampling sites (see Table 1). The sampling points are classified by the $\mathrm{Pb}$ content (Licht \& Tarvainen 1996).

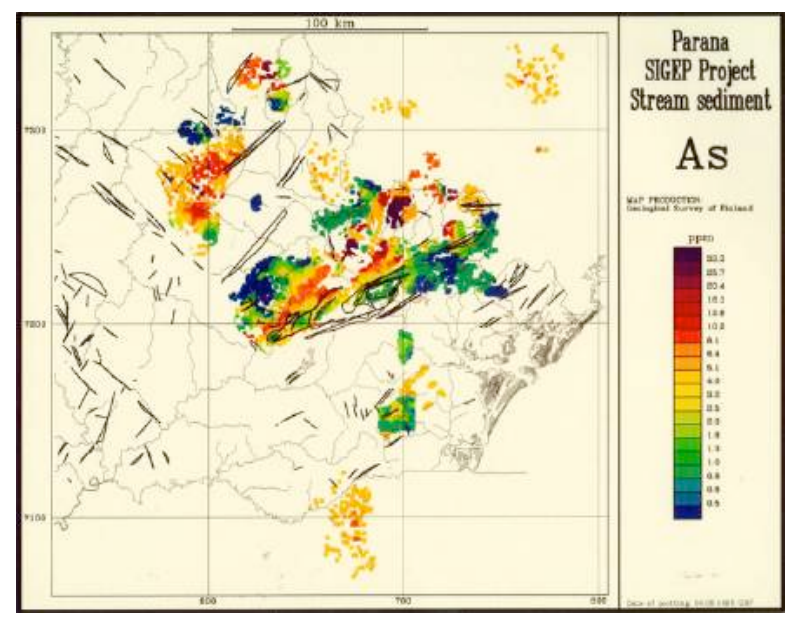

Figure 10

Geochemical map showing As distribution in stream sediments from 7,351 sampling sites (see Table 1). The sampling points are classified by the As content (Licht \& Tarvainen 1996).

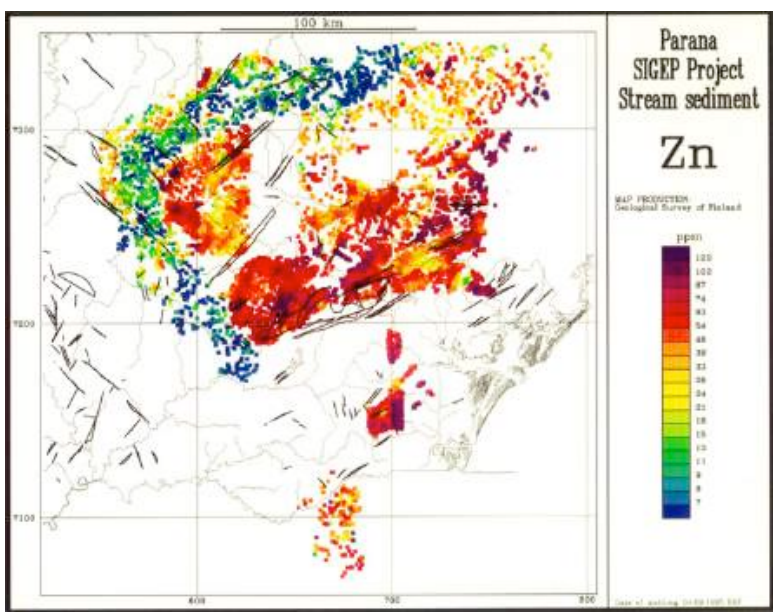

Figure 9

Geochemical map showing $\mathrm{Zn}$ distribution in stream sediments from 14,694 sampling sites (see Table 1). The sampling points are classified by the $\mathrm{Zn}$ content (Licht \& Tarvainen 1996).

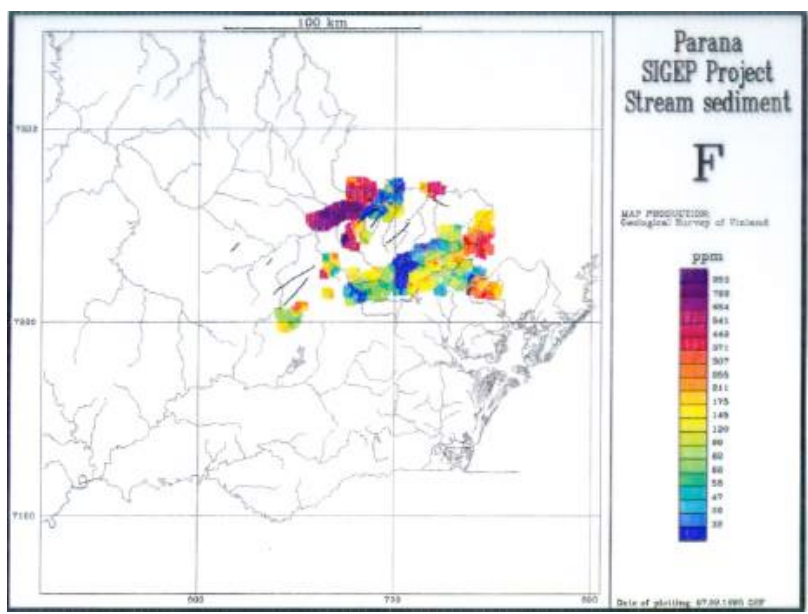

Figure 11

Geochemical surface showing $F$ distribution in stream sediments and pan concentrate from 2,270 sampling sites (see Table 2) (Licht \& Tarvainen 1996).

\subsection{GEOCHEMICAL ORIENTATION SURVEY OF UMUARAMA}

A geochemical orientation survey designed to characterize the impacts of human activity on the natural environment was considered of great importance for the interpretation of the data collected by the State of Paraná geochemical mapping project. To meet this need, the city of Umuarama, located in the northeastern region of the State of Paraná (Figure 3), was selected as a target for the research based on the following criteria: (1) it is situated on a topographic high so the hydrographic network flows out from the urban center; (2) the geological background is only represented by the Caiuá Group sandstones; (3) the soils have low natural fertility, which means they are relatively impoverished in many nutrient elements; (4) a well-concentrated urban center of about 70,000 inhabitants that shows a relatively defined socioeconomic zoning; (5) the industrial activity is composed of small- to medium-sized factories, but restricted to the southeastern region. The sampling plan has considered the urban and peri-urban area, the urban and industrial occupation and the socialeconomic zoning of the citizens as well. Thus, stream water and sediment samples were collected in 29 strategically distributed sampling sites (Figure 12).

Additionally, in the same sampling sites, physicochemical parameters such as temperature, $\mathrm{pH}$, dissolved oxygen and electrical conductivity were obtained by direct reading in the river water using multi-parameter equipment. The samples 
were submitted to the analytical procedures summarized in Table 3.

Some of the geochemical maps produced by the Geochemical Orientation Survey of Umuarama are presented in Figures 13a, 13b, $13 \mathrm{c}$, and $13 \mathrm{~d}$.

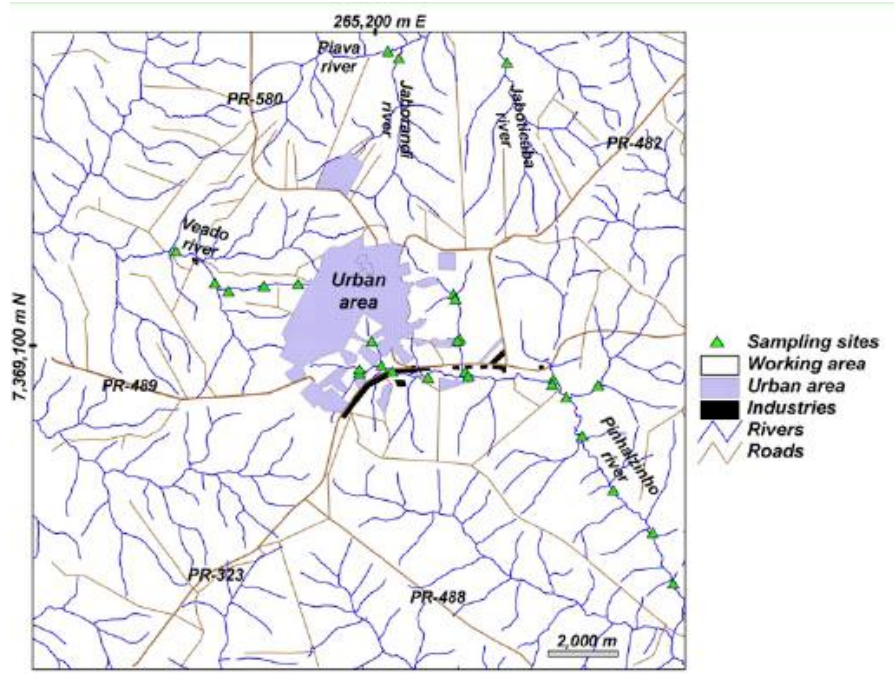

Figure 12

Sampling plan of the Geochemical Orientation Survey of Umuarama

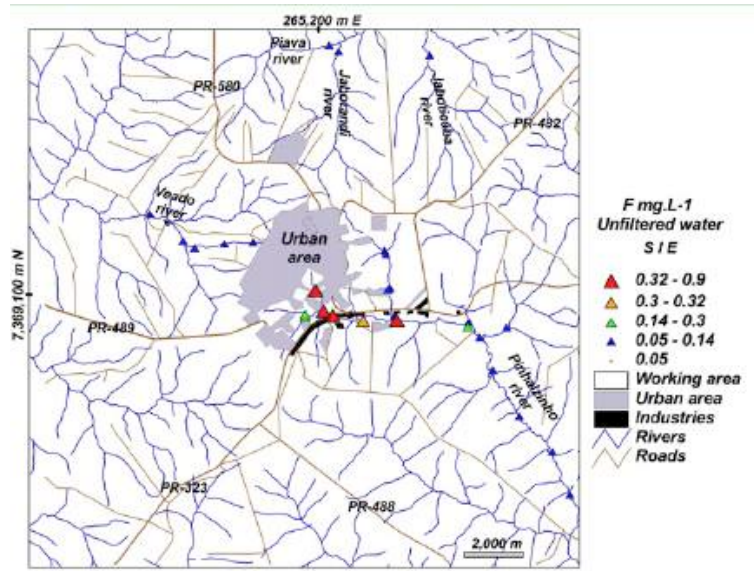

a
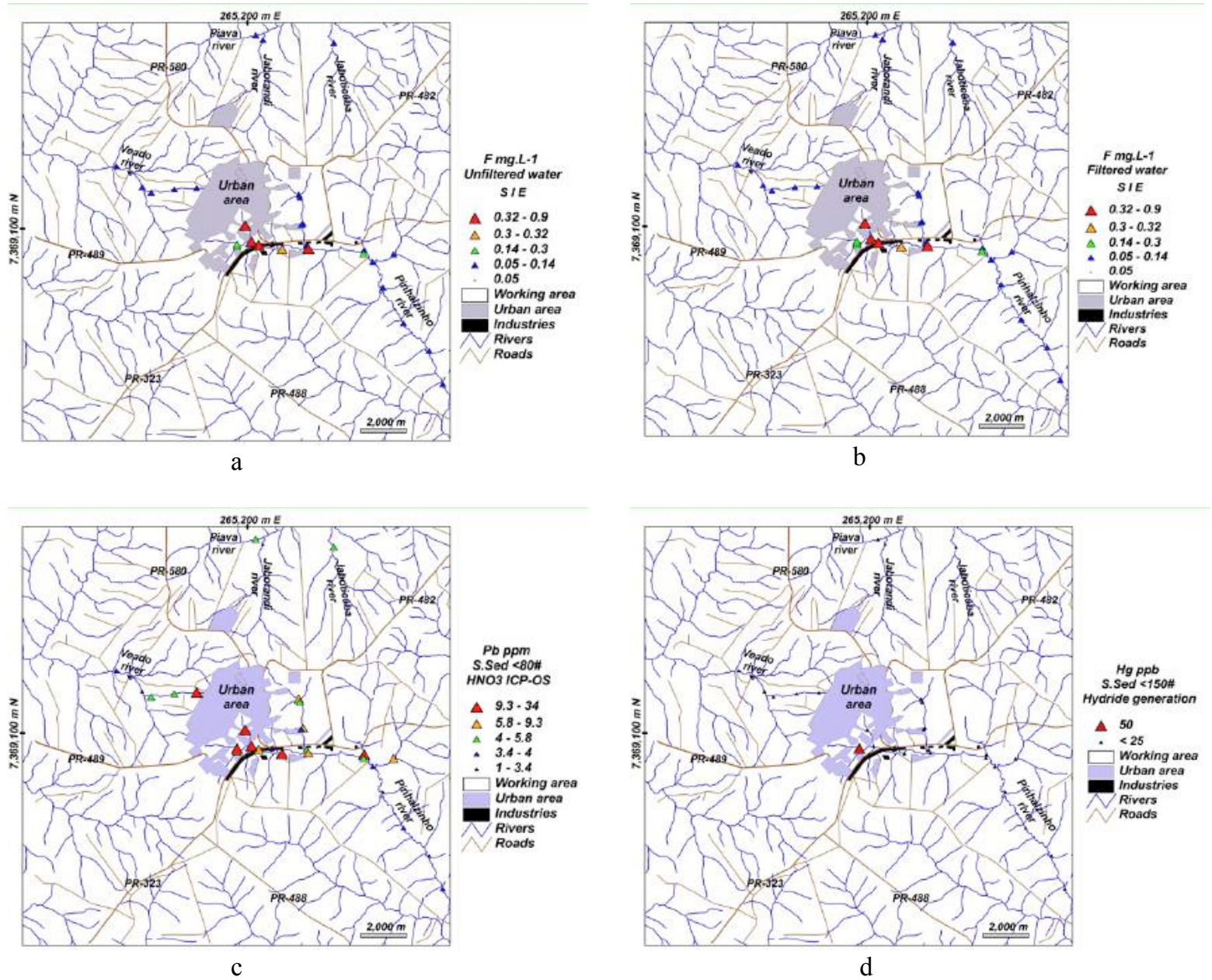

Figure 13

Content of selected elements and sampling media in the Umuarama's urban-industrial area also showing the content's decay as the distance to the urban-industrial area increases. 
Table 3 - Sampling media and fractions, and analytical procedures applied in the Orientation Geochemical Study of Umuarama.

\begin{tabular}{|c|c|c|c|}
\hline $\begin{array}{l}\text { Sampling } \\
\text { media }\end{array}$ & Fraction & Extraction & Elements or parameters \\
\hline \multirow{4}{*}{ Stream water } & in situ & multi-parameter equipment & $\begin{array}{l}\mathrm{pH}, \text { temperature, dissolved oxygen, } \\
\text { electric conductivity }\end{array}$ \\
\hline & raw (unfiltered) & ICP-OS & \multirow{3}{*}{$\begin{array}{c}\mathrm{Al}, \mathrm{Ag}, \mathrm{As}, \mathrm{B}, \mathrm{Ba}, \mathrm{Be}, \mathrm{Bi}, \mathrm{Ca}, \mathrm{Cd}, \mathrm{Co}, \mathrm{Cr}, \mathrm{Cu}, \mathrm{F}, \mathrm{Fe}, \mathrm{K} \\
\mathrm{La}, \mathrm{Li}, \mathrm{Mg}, \mathrm{Mn}, \mathrm{Mo}, \mathrm{Na}, \mathrm{Ni}, \mathrm{P}, \mathrm{Pb}, \mathrm{Sc}, \mathrm{Sr}, \mathrm{Ti}, \mathrm{V}, \mathrm{W}, \mathrm{Y} \\
\mathrm{Zn}\end{array}$} \\
\hline & evaporation residue & aqua regia- ICP-OS & \\
\hline & filtered & milipore $90 \mu \mathrm{m}$ - ICP-OS & \\
\hline \multirow{6}{*}{$\begin{array}{l}\text { Active stream } \\
\text { sediments }\end{array}$} & $\begin{array}{c}<40 \# \\
(0,420 \mathrm{~mm})\end{array}$ & EDTA $5 \%$ - ICP-OS & $\begin{array}{c}\mathrm{Al}, \mathrm{Ag}, \mathrm{As}, \mathrm{B}, \mathrm{Ba}, \mathrm{Be}, \mathrm{Bi}, \mathrm{Ca}, \mathrm{Cd}, \mathrm{Co}, \mathrm{Cr}, \mathrm{Cu}, \mathrm{Fe}, \mathrm{K}, \mathrm{La}, \\
\mathrm{Li}, \mathrm{Mg}, \mathrm{Mn}, \mathrm{Mo}, \mathrm{Na}, \mathrm{Ni}, \mathrm{P}, \mathrm{Pb}, \mathrm{Sc}, \mathrm{Sr}, \mathrm{Ti}, \mathrm{V}, \mathrm{W}, \mathrm{Y}, \mathrm{Zn}\end{array}$ \\
\hline & \multirow{2}{*}{$\begin{array}{c}<80 \# \\
(0,177 \mathrm{~mm})\end{array}$} & Aqua regia - ICP-OS & $\begin{array}{c}\mathrm{Al}, \mathrm{Ag}, \mathrm{As}, \mathrm{B}, \mathrm{Ba}, \mathrm{Be}, \mathrm{Bi}, \mathrm{Ca}, \mathrm{Cd}, \mathrm{Co}, \mathrm{Cr}, \mathrm{Cu}, \mathrm{Fe}, \mathrm{K}, \mathrm{La}, \\
\mathrm{Li}, \mathrm{Mg}, \mathrm{Mn}, \mathrm{Mo}, \mathrm{Na}, \mathrm{Ni}, \mathrm{P}, \mathrm{Pb}, \mathrm{Sc}, \mathrm{Sr}, \mathrm{Ti}, \mathrm{V}, \mathrm{W}, \mathrm{Y}, \mathrm{Zn}\end{array}$ \\
\hline & & $\mathrm{XRF}$ & $\mathrm{Nb}, \mathrm{Zr}, \mathrm{Sn}$ \\
\hline & \multirow{3}{*}{$\begin{array}{c}<150 \# \\
(0,106 \mathrm{~mm})\end{array}$} & Hydride generation - AAS & $\mathrm{Se}, \mathrm{Te}$ \\
\hline & & Hydride generation - AAS & $\mathrm{Hg}$ \\
\hline & & Alcaline fusion - EIE & $\mathrm{F}$ \\
\hline
\end{tabular}

Notes: ICP-OS: induced coupled plasma - optical spectrometry; XRF: X-ray fluorescence; AAS - atomic absorption spectrometry;

SIE specific ion eletrode

This complex set of sub-samples and analytical techniques produced a geochemical database containing 7,337 values. The results of the Geochemical Orientation Study of Umurarama were presented by Piekarz \& Ignácio (1997), and the main conclusions are summarized in section 3. Results and Conclusions.

\subsection{GEOCHEMICAL SURVEY OF THE CURITIBA TOPOGRAPHIC SHEET SG-22-XD-I (1:100,000)}

This project aimed to characterize and compare the distribution of chemical elements in urban and peri-urban environments and rural surroundings, i.e., regions with varying intensities and types of human occupation (Figure 14). The sampling was planned in order to provide full coverage of the Curitiba topographic sheet, comprising an area of $2,500 \mathrm{~km}^{2}$. The catchment basins ranged between $0,62 \mathrm{~km}^{2}$ e $5,4 \mathrm{~km}^{2}$ (Figure 15). In the most densely urban region, i.e., the central and northern regions of the city territory, the basins cover larger areas, as the plumbing system designed to drain rainwater altered the natural pattern of the watershed network. A total of 392 sediment samples were collected in the axis of the river channel, where water flows more intensely. Each sample is composed of five sub-samples, taken a few meters apart. The samples were collected in two field campaigns: (1) between March and June 1995, where two CPRM teams collected about $95 \%$ of the samples only in peri-urban and rural areas; (2) between 8th and 18th August 1995, where a MINEROPAR team sampled the dense urban area solely.

The samples were dried, disaggregated, and sieved to 80 mesh $(0.177 \mathrm{~mm})$. Partial digestion carried out by MINEROPAR supplemented the analyses with strong digestion made by CPRM-
SGB. The samples were submitted to the analytical procedures summarized in Table 4. Such diverse chemical approaches were selected to identify elemental distribution patterns, identifying those related to nature or produced by human activities.

The Geochemical Atlas of Curitiba (Licht 2001c) synthesized the procedures adopted in the field, laboratory and data processing and geochemical maps of the analyzed elements. The maps showing the element distribution are accompanied by a brief description of the geochemical characteristics of the element and its associations with natural or human-made processes. Some of these maps are presented in Figure 16.

Transparent plastic blades containing the hydrographic network, sampled basins, geology, region of highest population density and the road network, plotted on the same scale of the geochemical maps, were provided in a back cover envelope. The overlap of these transparent base maps on the geochemical maps facilitates the interpretations by readers of multiple formations and various interests. The main conclusions are summarized in section 3. Results and Conclusions. 


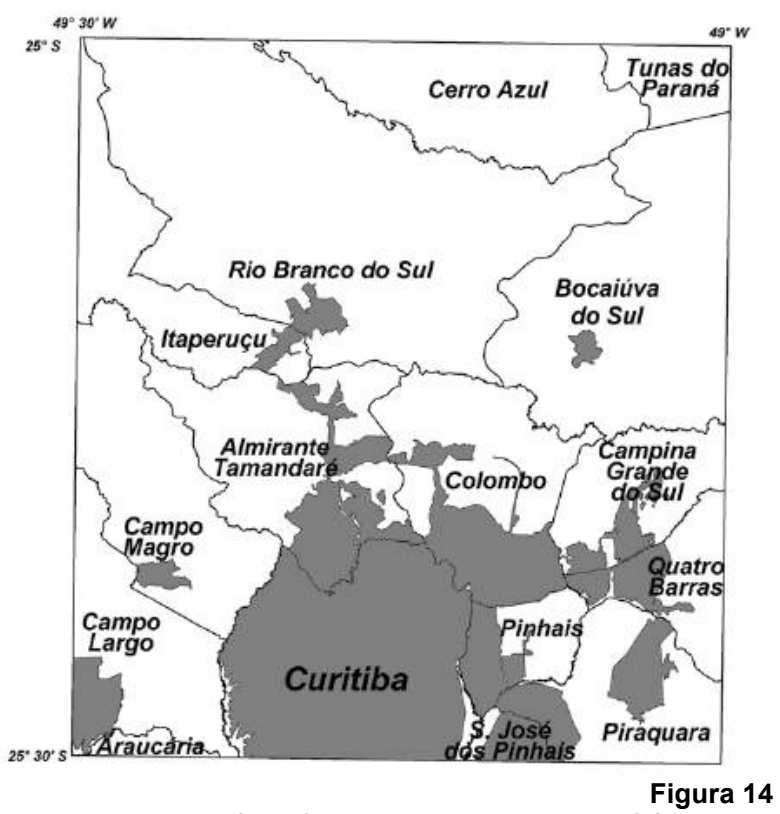

Urban areas of the Curitiba topographic sheet SG-22-XD-I

$(1: 100,000)$.

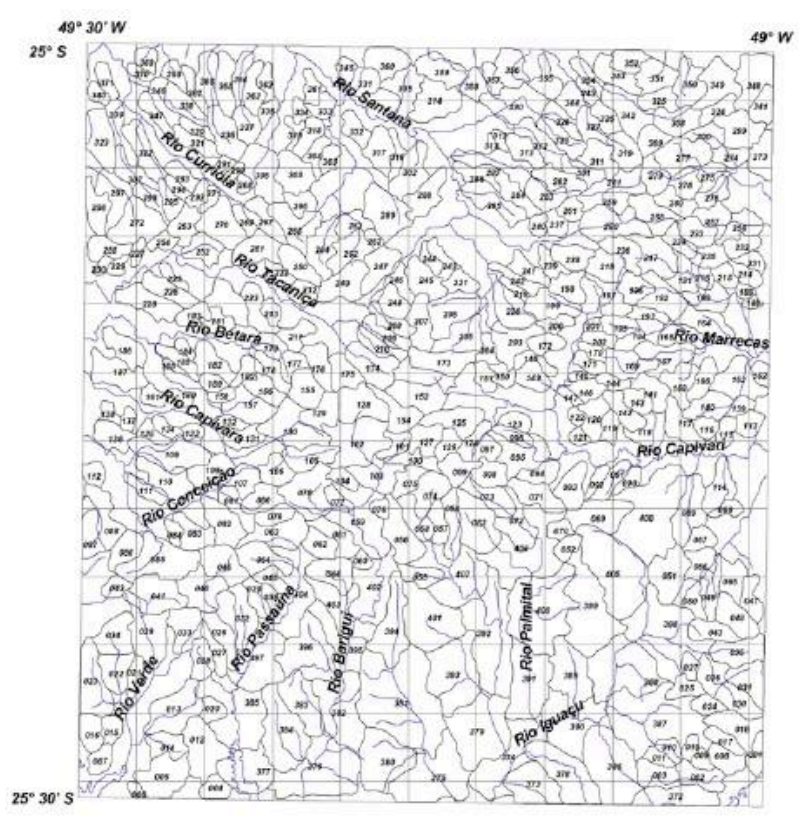

Figure 15

Catchment basins and the sampling plan for the Geochemical Survey of the Curitiba topographic sheet SG-22-XD-I

$(1: 100,000)$.

Table 4 - Analytical procedures adopted by the Geochemical Survey of the Curitiba topographic sheet $(1: 100,000)$.

\begin{tabular}{|c|c|c|c|}
\hline $\begin{array}{c}\text { Sampling } \\
\text { media }\end{array}$ & Fraction & Extraction & Elements or parameters \\
\hline \multirow{6}{*}{$\begin{array}{l}\text { Active stream } \\
\text { sediments }\end{array}$} & \multirow{6}{*}{$\begin{array}{c}<80 \# \\
(0.177 \mathrm{~mm})\end{array}$} & $\begin{array}{l}\text { Aqua regia }- \text { EAA } \\
(\text { CPRM })\end{array}$ & $\mathrm{Ag}, \mathrm{Au}, \mathrm{Ba}, \mathrm{Bi}, \mathrm{Cd}, \mathrm{Co}, \mathrm{Cr}, \mathrm{Cu}, \mathrm{Fe}, \mathrm{Li}, \mathrm{Mo}, \mathrm{Ni}, \mathrm{Zn}$ \\
\hline & & $\begin{array}{l}\text { EDTA 5\% - ICP-OS } \\
\text { (MINEROPAR) }\end{array}$ & $\begin{array}{l}\mathrm{Ag}, \mathrm{Al}, \mathrm{As}, \mathrm{Ba}, \mathrm{Be}, \mathrm{Bi}, \mathrm{Ca}, \mathrm{Cd}, \mathrm{Co}, \mathrm{Cr}, \mathrm{Cu}, \mathrm{Fe}, \mathrm{K}, \mathrm{La}, \mathrm{Li} \text {, } \\
\mathrm{Mo}, \mathrm{Mg}, \mathrm{Mn}, \mathrm{Na}, \mathrm{Ni}, \mathrm{P}, \mathrm{Pb}, \mathrm{Sb}, \mathrm{Sc}, \mathrm{Sr}, \mathrm{Ti}, \mathrm{V}, \mathrm{W}, \mathrm{Y}, \mathrm{Zn}\end{array}$ \\
\hline & & $\begin{array}{c}\text { Optical Emission Spectrometry - } \\
\text { OES } \\
\text { (MINEROPAR) } \\
\end{array}$ & $\mathrm{Nb}, \mathrm{Sn}, \mathrm{Zr}$ \\
\hline & & $\begin{array}{l}\text { Hydride generation - EAA } \\
\text { (MINEROPAR) }\end{array}$ & $\mathrm{As}, \mathrm{Sb}, \mathrm{Se}, \mathrm{Te}, \mathrm{Hg}$ \\
\hline & & $\begin{array}{l}\text { Alcaline fusion - EIE } \\
\text { (MINEROPAR) }\end{array}$ & $\mathrm{F}$ \\
\hline & & $\begin{array}{c}\text { Colorimetry } \\
\text { (MINEROPAR) }\end{array}$ & W \\
\hline
\end{tabular}

\subsection{STATE OF PARANÁ LOW-DENSITY GEOCHEMICAL SURVEY}

The sampling was planned in order to provide comprehensive and representative coverage of the State of Paraná territory. Stream water and sediment samples were collected in 696 watersheds in an area of $165,646 \mathrm{~km}^{2}$, which represents $83 \%$ of the State of Paraná. The size of the sampled basins varied between $26 \mathrm{~km}^{2}$ and $183 \mathrm{~km}^{2}$ (Figure 17).

In order to collect samples in the shortest time lapse possible, the project included the participation of almost all local offices of the EMATER-PR, the State Agency for Agriculture. Kits containing the necessary materials for sampling were assembled and distributed to the agronomists and technicians of EMATER-PR, accompanied by a demonstration of all field procedures. Thanks to a large number of sampling teams, $90 \%$ of fieldwork was carried out from October $15^{\text {th }}$ to December $12^{\text {th }}, 1995$. A MINEROPAR team sampled some isolated basins not sampled in this first phase from April $28^{\text {th }}$ to June $28^{\text {th }}$, 1997. The water samples were collected at a single site and stored in $250 \mathrm{ml}$ polyethylene bottles, which were carefully washed with the river water of the sampling site. To increase representativeness and to reduce sampling bias the sediment samples were collected by hand in five sub-samples few meters apart, totaling ten liters. The water samples have been sent to the LAMIN-CPRM lab where they were filtered in a $90 \mu \mathrm{m}$ Millipore filter. Active sediment samples were dried at room temperature, disaggregated in a porcelain mortar with a rubber pistil and sieved with an 80 \# $(0.177$ $\mathrm{mm}$ ) nylon sieve in the MINEROPAR's laboratory. The $<80$ \# pulps were then sent to LAMIN, the CPRM laboratory for analytical procedures (Table 5). A replicate of all samples was adequately stored for more sensitive analyses in the future. 
The Geochemical Atlas of Paraná (Licht 2001b) synthesized the concepts of regional geochemical mapping and techniques adopted in the field, laboratory and data processing by the Low-Density Geochemical Survey of the State of Paraná. The colored maps containing the element distribution were accompanied by a brief description of the geochemical characteristics of that element and its associations with natural or human-made processes.

Due to the small number of samples with detectable values geochemical maps were not prepared for $\mathrm{Ag}, \mathrm{B}, \mathrm{Cd}, \mathrm{Co}, \mathrm{Cr}, \mathrm{Cu}, \mathrm{Ga}, \mathrm{In}, \mathrm{Li}, \mathrm{Mo}$, $\mathrm{Ni}, \mathrm{Pb}, \mathrm{Tl}, \mathrm{V}, \mathrm{W}, \mathrm{Zn}$ in water and $\mathrm{Ag}$ in stream sediments.

Geochemical maps showing the regional distribution and the variability of the contents of each analytical parameter were obtained by applying interpolation techniques (section 2.9. Geochemical mapping techniques). The hydrogeochemical maps are shown in Figure 19.

Selected geochemical maps showing the distribution and regional variability of the contents in stream sediments are presented in Figure 20.

In order to support the interpretation of the geochemical patterns, transparent plastic sheets containing the hydrographic network, sampled basins, geology, region of highest population density and the road network, plotted on the same scale of the geochemical maps, were provided in the back cover. Other details and multi-purpose interpretation of geochemical data of the Low-Density Multielement Regional Survey are found in Licht et al. (1997), and Licht (2001a, 2005) but the main conclusions are summarized in section 3. Results and Conclusions.

\subsection{STATE OF PARANÁ SOILS GEOCHEMICAL SURVEY - B HORIZON}

The second phase of the Low-Density Geochemical Survey of the State of Paraná focused on the geochemical characterization of soils (B horizon). The sampling sites were designed to obey a quite regular grid of 15 ' x 15', or ca. $25 \mathrm{~km} \times 25$ $\mathrm{km}$ at that latitude, coinciding with the center of the 307 1:50,000 topographic sheets which cover the State of Paraná (Figure 21). The original points were then shifted to be as near as possible (a) to the center of the $1: 50,000$ sheets (b) to a nearby road to facilitate the access of field teams, (c) on the top of a hill to reduce the risk of collection of transported soil.

The $2 \mathrm{~kg}$ soil samples were obtained by digging a channel in road cuts or, when it was necessary to properly reach the $\mathrm{B}$ horizon, by digging a well with a shovel. All samples were collected by the
MINEROPAR team between November 2001 and May 2003. The samples were dried at room temperature, disaggregated with a porcelain mortar and a rubber pistil and sieved with an $80 \#(0.177$ $\mathrm{mm}$ ) nylon mesh in the MINEROPAR laboratory. The summary of analytical procedures applied by many laboratories is available at Table 6 .

The sampling techniques, preparation, analytical and quality control protocols, as well as the data processing, are exposed in detail in the final report of the Soil (B horizon) Geochemical Mapping of the State of Paraná (Licht \& Plawiak, 2005). This report also contains data and statistical tables, distribution maps and interpretations for the distribution of each measured variable or elements in the State of Paraná territory. The main conclusions are summarized in section 3. Results and Conclusions.

\subsection{GLOBAL GEOCHEMICAL REFERENCE NETWORK GGRN}

SIGEP adopted the Global Geochemical Reference Network (GGRN) proposed by the project IGCP-259 (International Geochemical Mapping) (Darnley et al. 1995). However, the GGRN cells measuring $1^{\circ} 30^{\prime}$ side, as proposed for a planetary scale, are equivalent to ca. $160 \mathrm{~km}$ at the State of Paraná latitude, which is considered too large to adequately represent the distribution patterns of the chemical elements in the area. Therefore, in order to improve the spatial resolution, each GGRN cell was subdivided into four sub-cells measuring $45^{\prime}$ side (ca. $80 \mathrm{~km}$ ) (Figure 22), thus totaling 39 sub-cells for the stream sediment samples and 43 sub-cells for the soils (Licht 2001a) as shown in Figure 23 and Figure 24, respectively.

Following the IGCP-259 concepts, all samples contained in each GGRN sub-cell contributed to the production of a $100 \mathrm{~g}$ composite sample. Thus, 39 composite samples were produced from the 696 original stream sediment samples, whereas 43 composite samples were prepared from the 307 original soil samples (B horizon). The multielemental analysis of the composite samples was carried out in the laboratories of the Institute of Geophysical and Geochemical Exploration (IGGE), Langfang, P.R. China. The best suited analytical procedures were applied to achieve the lowest detection limits as possible, in which 69 oxides or elements were determined for the stream sediment samples and 71 for the soil samples (Table 7). With sophisticated analytical procedures, extremely low contents such as $0.32 \mathrm{ppb} \mathrm{Pt}$ and $0.54 \mathrm{ppb} \mathrm{Pd}$, were identified in the samples. 

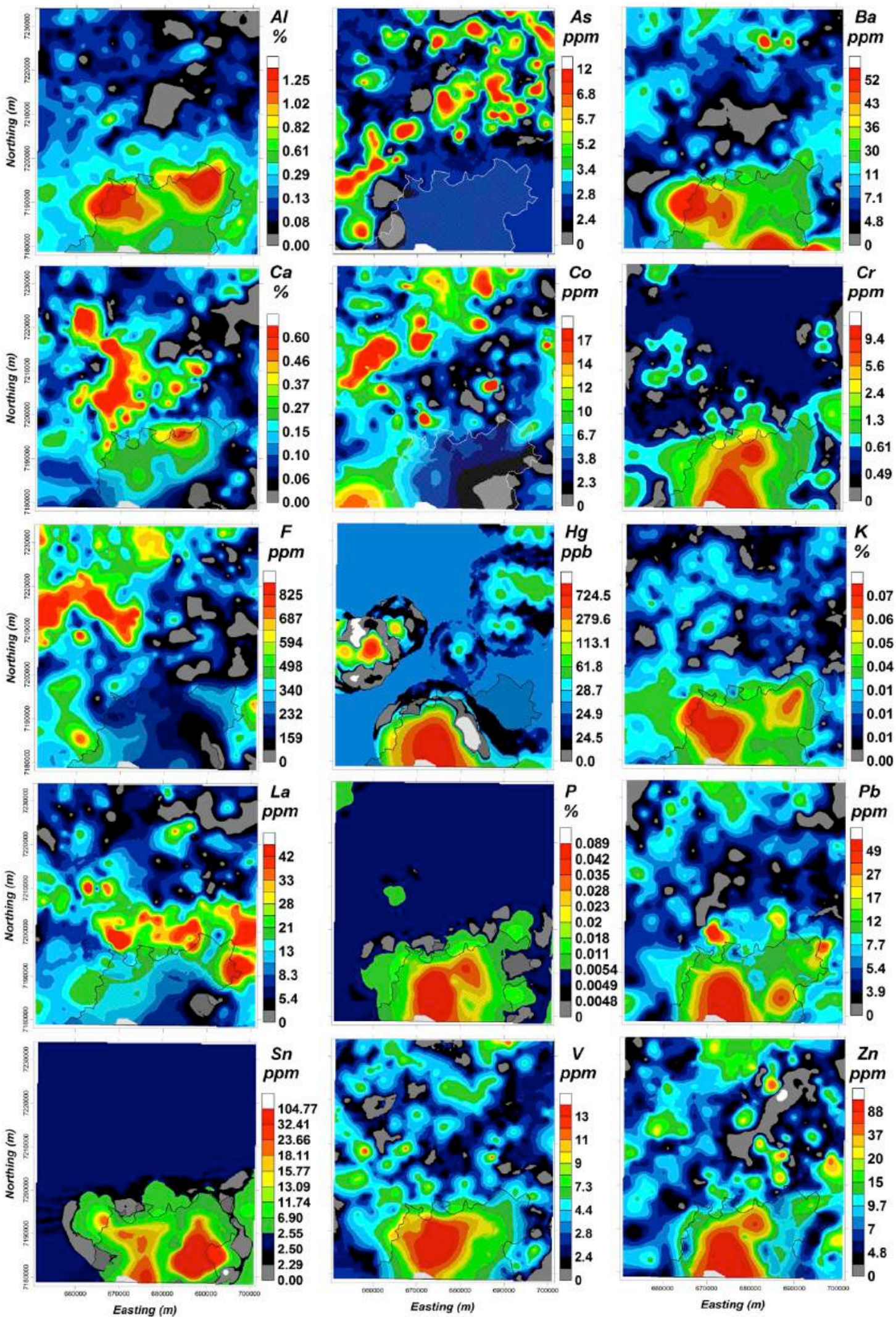

Figure 16

The geochemical survey of the Curitiba topographic sheet SG-22-XD-I $(1: 100,000)$ geochemical maps showing the distribution of elements analyzed by MINEROPAR (see Table 4). The shaded polygon located in the center-south portion of the maps delineates the densely populated area of Curitiba and some neighbor municipalities (see Figure 14). 


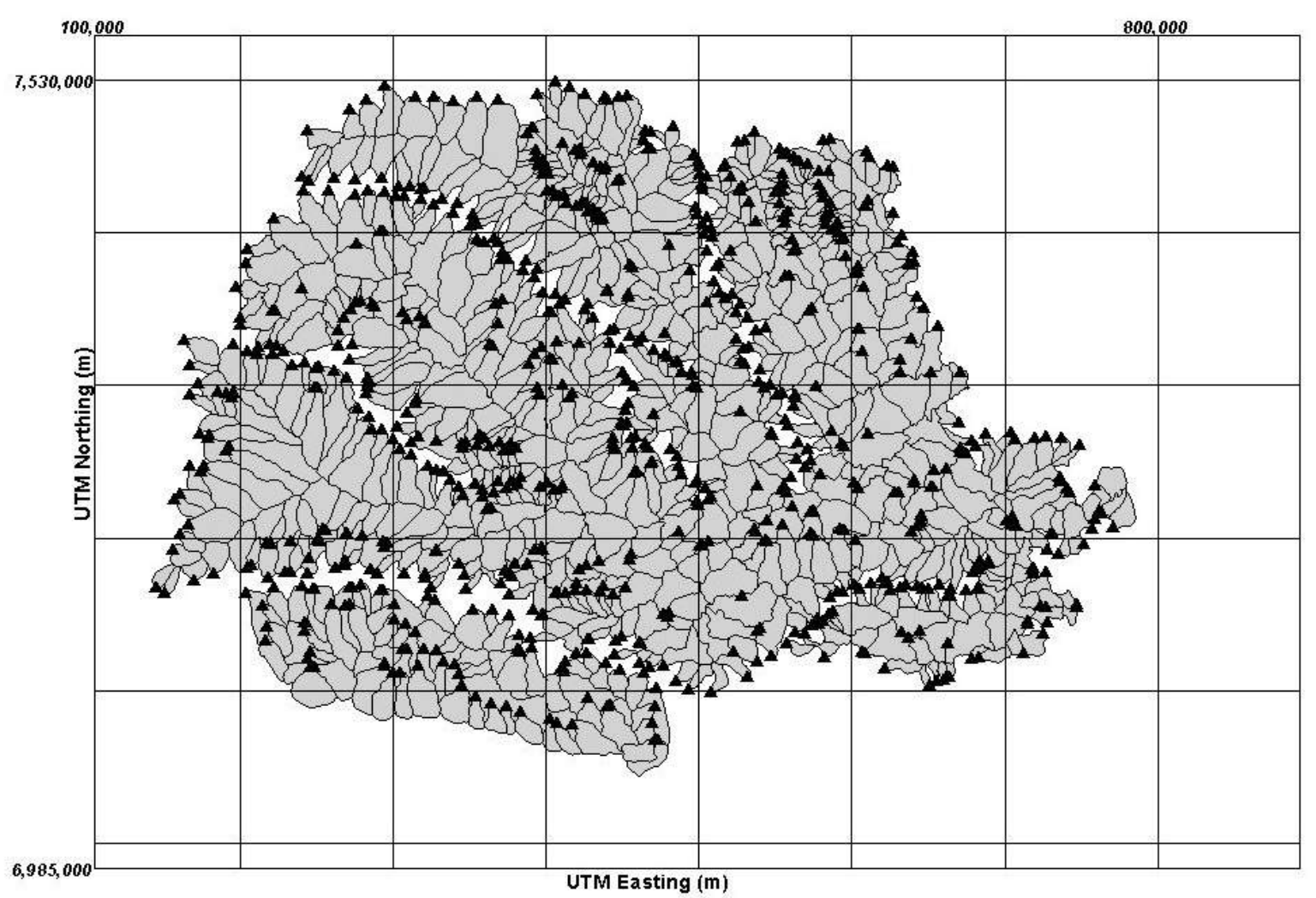

Figure 17

Sampling plan for the State of Paraná Low-density Geochemical Survey - the collection of water and stream sediments samples.

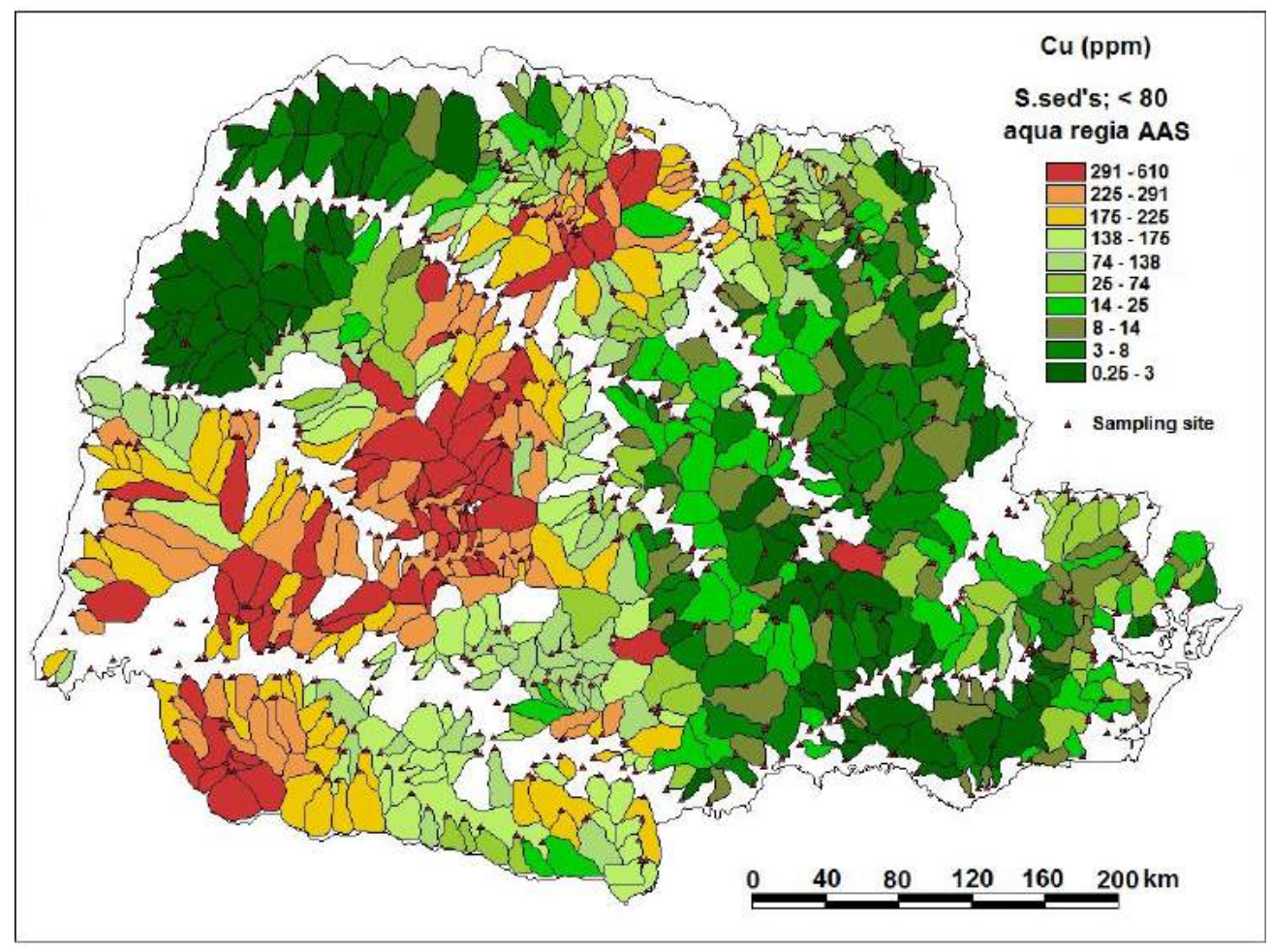

Figure 18 Low-Density Geochemical Survey of the State of Paraná. The catchment basins are classified according to their Cu content. 

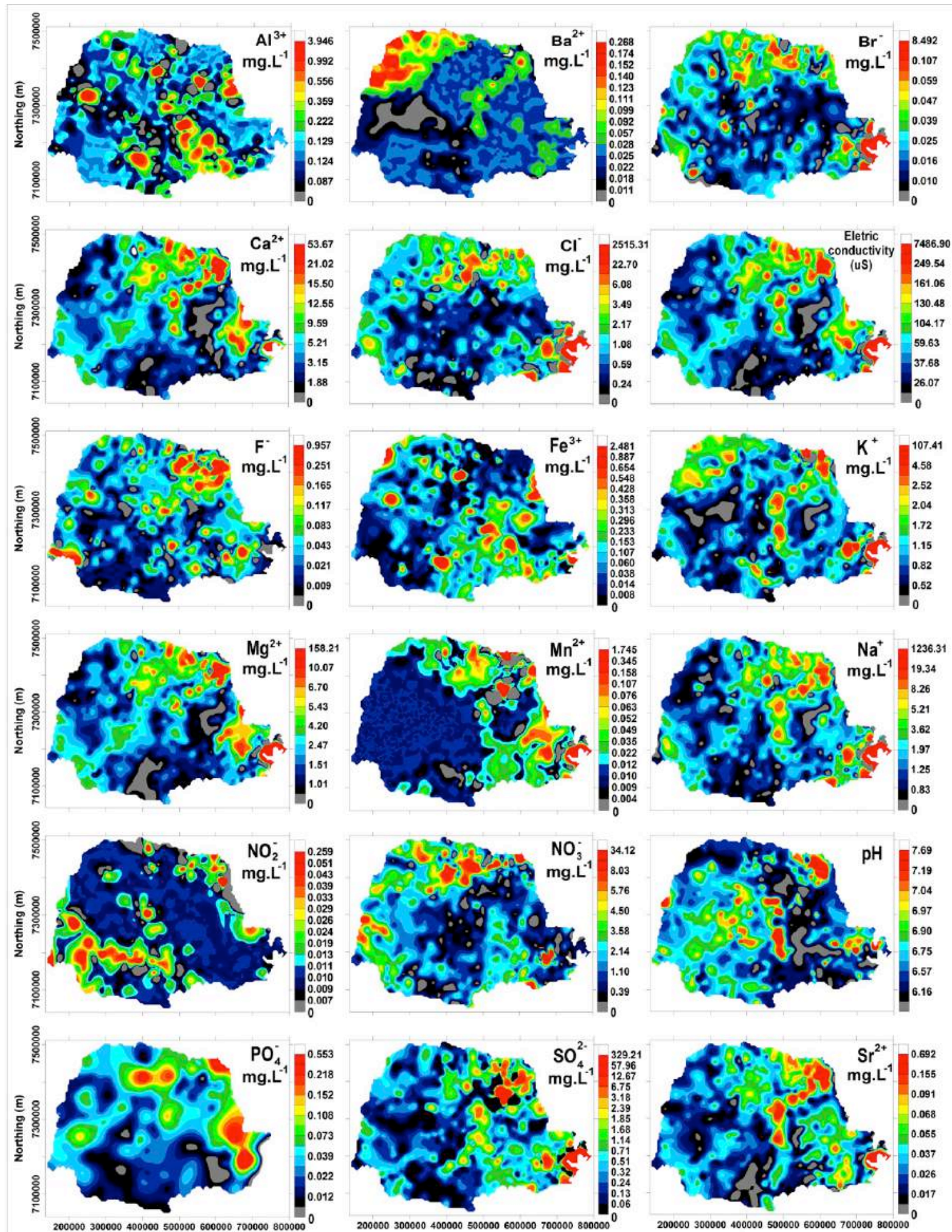

Easting ( $m$ )

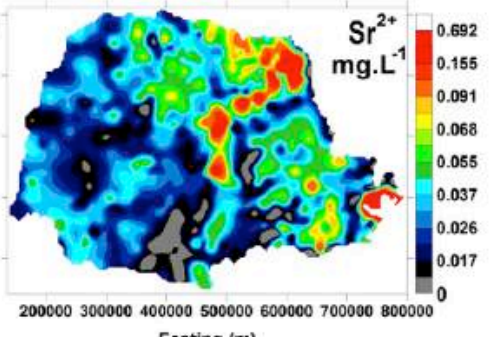

Figure 19

Low-Density Geochemical Survey covering the State of Paraná. Geochemical maps showing the distribution of the analyzed variables in stream water (see Table 5). 


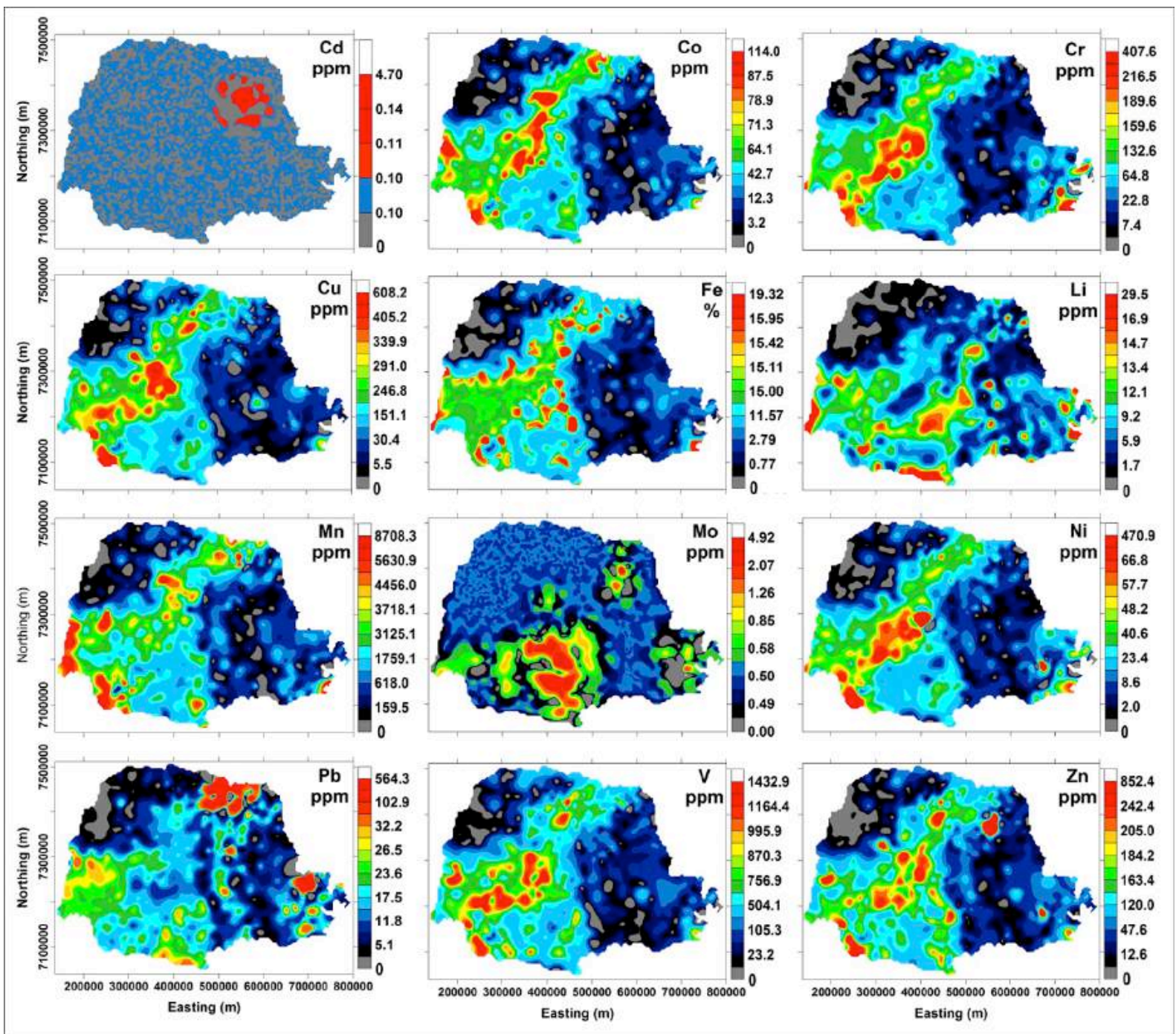

Figure 20

Low-Density Geochemical Survey covering the State of Paraná. Geochemical maps showing the distribution of the analyzed variables in stream sediments (see Table 5).

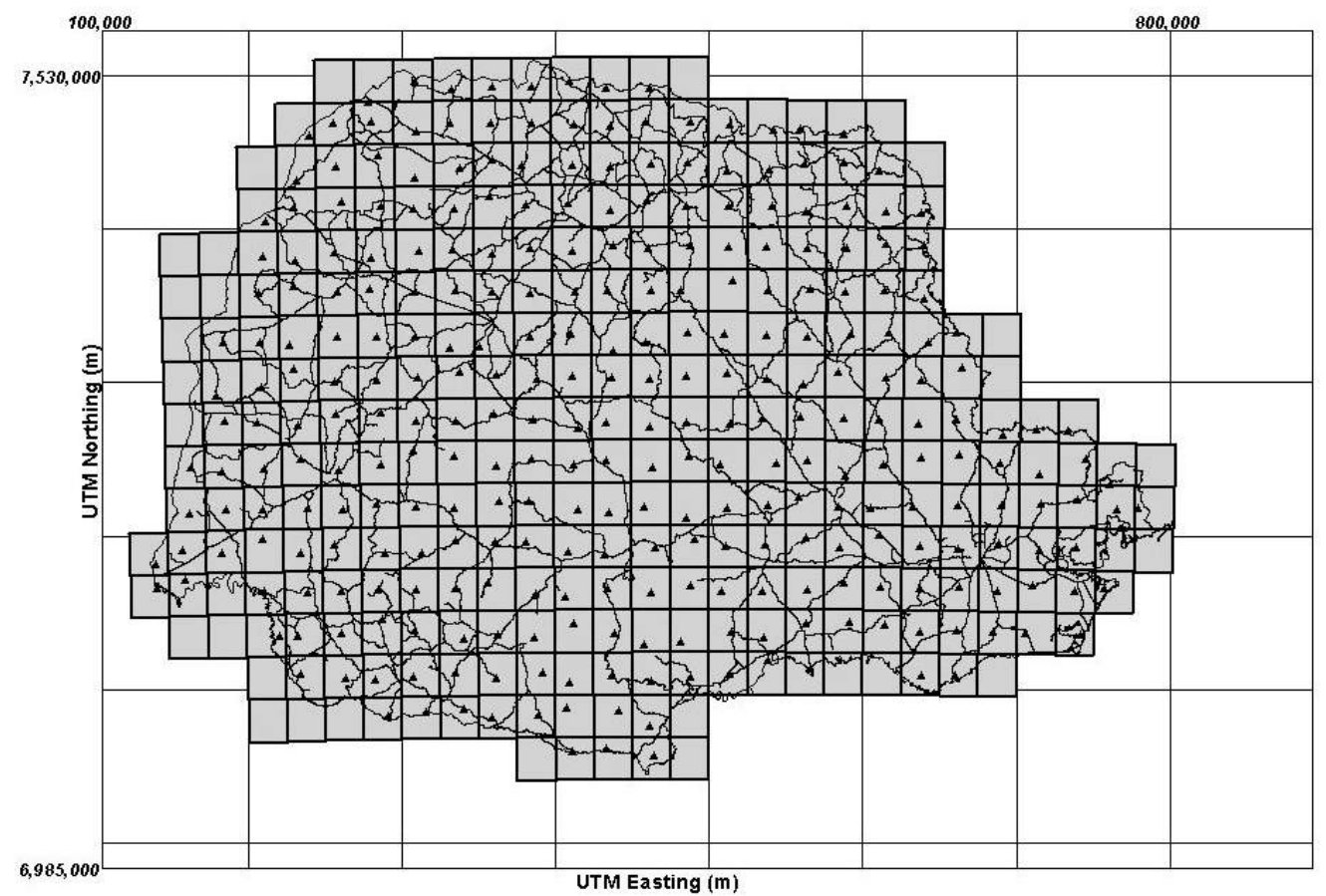

Figure 21

Sampling plan of the State of Paraná Soils Geochemical Survey - B horizon. Each sample was collected nearly in the center of each $1: 50,000$ topographic sheet. 
Table 5 - Sampling media and fractions, and analytical procedures adopted by the Geochemical Survey of the State of Paraná.

\begin{tabular}{|c|c|c|c|}
\hline $\begin{array}{c}\text { Sampling } \\
\text { media }\end{array}$ & Fraction & Extraction & Elements or parameters \\
\hline \multirow{3}{*}{ Stream water } & raw & On-site reading & $\mathrm{pH}$, electric conductivity \\
\hline & \multirow[b]{2}{*}{$\begin{array}{l}\text { filtered with } \\
\text { millipore } 90 \mu \mathrm{m}\end{array}$} & $\begin{array}{c}\text { Ion chromatography } \\
\text { IC }\end{array}$ & $\mathrm{Br}^{-}, \mathrm{Cl}^{-}, \mathrm{F}^{-}, \mathrm{NO}_{2}^{-}, \mathrm{NO}_{3}^{-}, \mathrm{PO}_{4}{ }^{2-}, \mathrm{SO}_{4}{ }^{2-}$ \\
\hline & & $\begin{array}{c}\text { Optical induced coupled plasma } \\
\text { spectrometry } \\
\text { ICP-OS }\end{array}$ & $\begin{array}{c}\mathrm{Ag}, \mathrm{Al}, \mathrm{B}, \mathrm{Ba}, \mathrm{Ca}, \mathrm{Cd}, \mathrm{Co}, \mathrm{Cr}, \mathrm{Cu}, \mathrm{Fe}, \\
\mathrm{Ga}, \mathrm{In}, \mathrm{K}, \mathrm{Li}, \mathrm{Mg}, \mathrm{Mn}, \mathrm{Mo}, \mathrm{Na}, \mathrm{Ni}, \mathrm{Pb}, \\
\mathrm{Sr}, \mathrm{Tl}, \mathrm{V}, \mathrm{W}, \mathrm{Zn}\end{array}$ \\
\hline $\begin{array}{l}\text { Active stream } \\
\text { sediments }\end{array}$ & $\begin{array}{c}<80 \# \\
(0.177 \mathrm{~mm})\end{array}$ & $\begin{array}{c}\mathrm{HNO}_{3} \text { conc. hot } \\
+ \text { atomic absorption } \\
\text { spectrometry - EAA }\end{array}$ & $\begin{array}{c}\mathrm{Ag}, \mathrm{Cd}, \mathrm{Co}, \mathrm{Cu}, \mathrm{Cr}, \mathrm{Fe}, \mathrm{Li}, \mathrm{Mn}, \mathrm{Mo} \\
\mathrm{Ni}, \mathrm{Pb}, \mathrm{V} \text { e } \mathrm{Zn}\end{array}$ \\
\hline
\end{tabular}

Table 6 - Physicochemical analytical procedures applied in many laboratories on the soil samples (B horizon) covering the State of Paraná.

\begin{tabular}{|c|c|c|c|}
\hline Sampling media & $\begin{array}{c}\text { Number of } \\
\text { samples }\end{array}$ & Laboratory & Elements or parameters \\
\hline \multirow{4}{*}{$\begin{array}{c}\text { Soil } \\
\text { B horizon }\end{array}$} & 309 & $\begin{array}{l}\text { Soils and Plant Tissues } \\
\text { Laboratory - IAPAR, } \\
\text { Londrina }\end{array}$ & $\begin{array}{c}\mathrm{pH}, \mathrm{H}^{+}+\mathrm{Al}^{3+}, \mathrm{Al}_{\text {exchangeable }}, \mathrm{Ca}_{\text {absorbable }}, \mathrm{Mg}_{\text {absorbable }}, \mathrm{P}_{\text {absorbable }}, \\
\mathrm{K}_{\text {absorbable }}, \mathrm{Cu}_{\text {extractable }}, \mathrm{Zn}_{\text {extractable }}, \mathrm{Fe}_{\text {extractable }}, \mathrm{Mn}_{\text {extractable, }} \\
\mathrm{S}_{\text {extractable }}, \mathrm{B}_{\text {extractable }}, \mathrm{C}, \mathrm{Al} \%, \mathrm{~V} \% \text { (Base saturation), } \mathrm{T} \text { (Sum of } \\
\text { exchangeable cations), } \mathrm{S} \text { (Sum of exchangeable base) }\end{array}$ \\
\hline & 309 & $\begin{array}{c}\text { Soils Laboratory - Maringá } \\
\text { State University }\end{array}$ & $\begin{array}{c}\mathrm{Fe} \text { and } \mathrm{Al} \text { available on clay }\left(\mathrm{Fe}_{\mathrm{DCB}} \mathrm{e} \mathrm{Al}_{\mathrm{DCB}}\right) \\
\text { Low cristallinity } \mathrm{Fe} \text { and } \mathrm{Al}\left(\mathrm{Fe}_{\mathrm{o}} \text { e } \mathrm{Al}_{\mathrm{o}}\right) \\
\text { Thermogravimetry (ATG) } \\
\text { X Ray difractomery (DRX) } \\
\text { Magnetic susceptibility by mass units }\end{array}$ \\
\hline & 309 & $\begin{array}{c}\text { Applied Geophysics } \\
\text { Laboratory - LPGA-UFPR }\end{array}$ & Gamma spectrometry and magnetic susceptibility \\
\hline & 309 & $\begin{array}{c}\text { Remote Sensing } \\
\text { Laboratory, University of } \\
\text { Campinas }\end{array}$ & 2,000 channel multispectral-radiometer \\
\hline
\end{tabular}

Analytical procedures were monitored following internal IGGE laboratory protocols including duplicate analyses of original samples randomly distributed in the analytical batches and analyzing standard certified samples: GPt 1-8 for $\mathrm{Pt}$ and Pd; GAu 8-11 for $\mathrm{Au}$; and GSS1, GSS3, GSD9, GSD10 for the other elements and oxides. A detailed description of the laboratory procedures is found in Licht (2001a) and Licht \& Plawiak (2005).

The geochemical maps show the distribution of the 69 oxides and elements analyzed in the 39 stream sediment composite samples, were obtained by applying interpolating functions (see sector 2.9 Geochemical mapping techniques). Some of these geochemical maps are presented in Figure 25.

The same interpolation technique (see section 2.9 Geochemical mapping techniques) was applied to obtain geochemical maps presenting the distribution of the 71 elements analyzed in the 41 soil composite samples (Figure 26). 


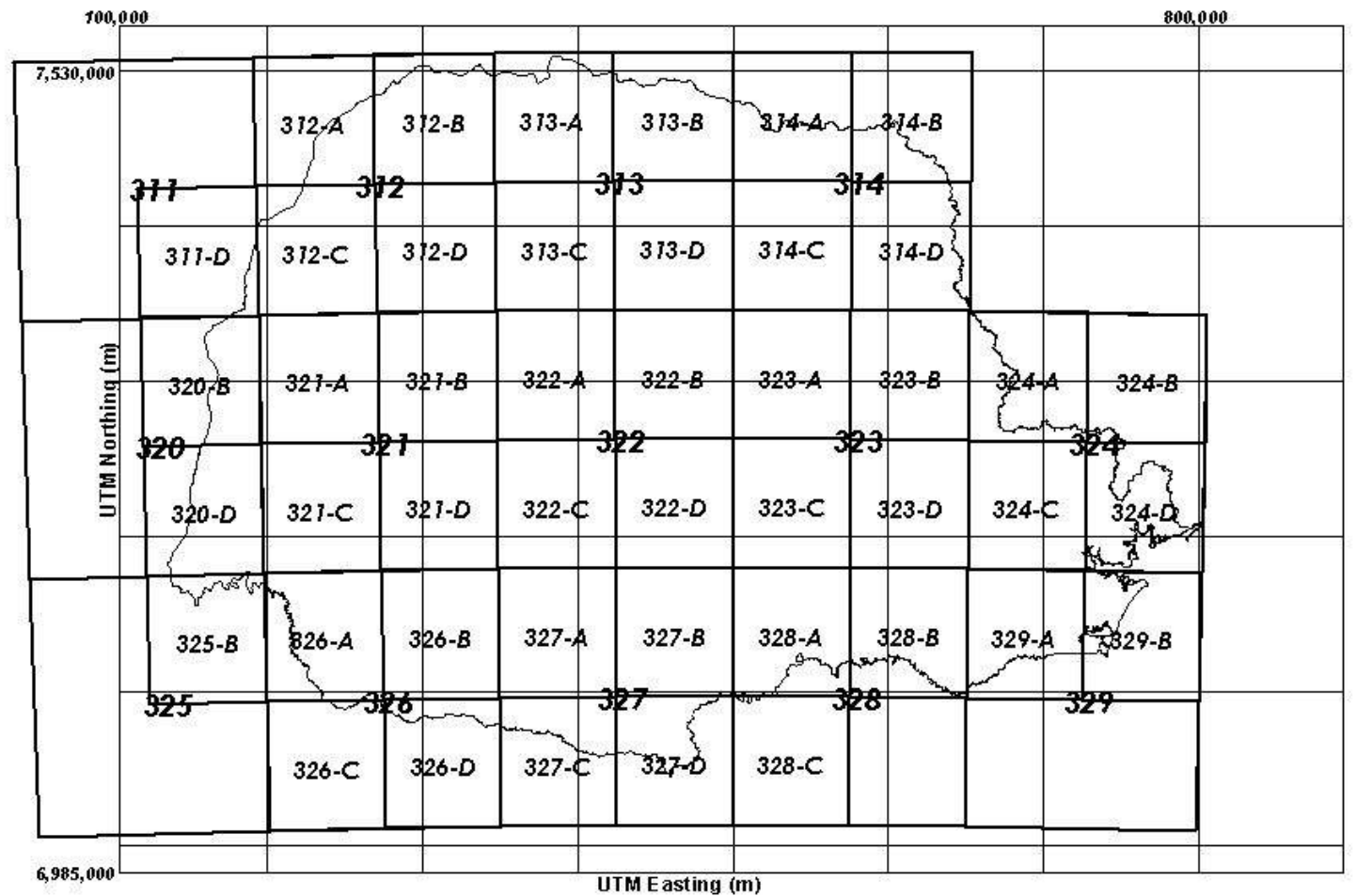

Figure 22

GGRN cells and the subdivision adopted in the State of Parana. Each $1^{\circ} 30^{\prime}$ GGRN cell was divided into four sub-cells, each sub-cell with $45^{\prime}$ side, i.e., ca. $80 \mathrm{~km}$ in that latitude, e.g., the GGRN cell number 322, comprises sub-cells 322-A, 322-B, 322-C, and 322-D.

\subsection{DATA PROCESSING}

In addition to the common statistical estimates, e.g., mean, variance and standard deviation, robust statistical estimates, e.g., median and quartiles, were adopted due to strong positive asymmetry and outliers. Statistical summaries for the Geochemical Survey of the Curitiba

\subsection{GEOCHEMICAL MAPPING TECHNIQUES}

The geochemical maps of all projects were produced in a way so that they represent the values of the variables in three manners: (1) point classified by selected percentiles and represented by a ramp of colors or by increasing diameters (Figure 8, 9 and 10); (2) classification of the catchment basins by selected percentiles and using a ramp of colors (Figure 18); (3) geochemical surfaces calculated with interpolation functions, selected to produce minor residues in each original point, i.e., to represent the original values with the highest fidelity (Figures 7, 11, 16, 19, 20, 25 and 26).

For the integration of previous mineral exploration projects (see section 2.1.) the geochemical surfaces were produced using
Topographic Sheet, for the Low-Density Geochemical Survey of the State of Paraná (stream water and stream sediments), and for the stream sediments and soil GGRN composite samples are presented in the Appendix on Tables $\mathrm{A}, \mathrm{B}, \mathrm{C}, \mathrm{D}$, and $\mathrm{E}$ respectively.

ALKEMIA software package developed at the Geological Survey of Finland. The element concentrations of the samples were first interpolated and smoothed from an irregular sampling distribution into a regular grid $(700 \mathrm{x}$ $700 \mathrm{~m}$ for the data shown in Table 1 and $200 \mathrm{x}$ $200 \mathrm{~m}$ for the data shown in Table 2). The grid values were calculated using a moving weighted median in a circular window (radius of $5 \mathrm{~km}$ for the data shown in Table 1 and radius of $2 \mathrm{~km}$ for the data shown in Table 2). For the data contained in Table 1, over 70 samples fell within the circular window. The weight $w$ for each sample was calculated using the Butterworth function (Equation 1) (Licht \& Tarvainen 1996). 


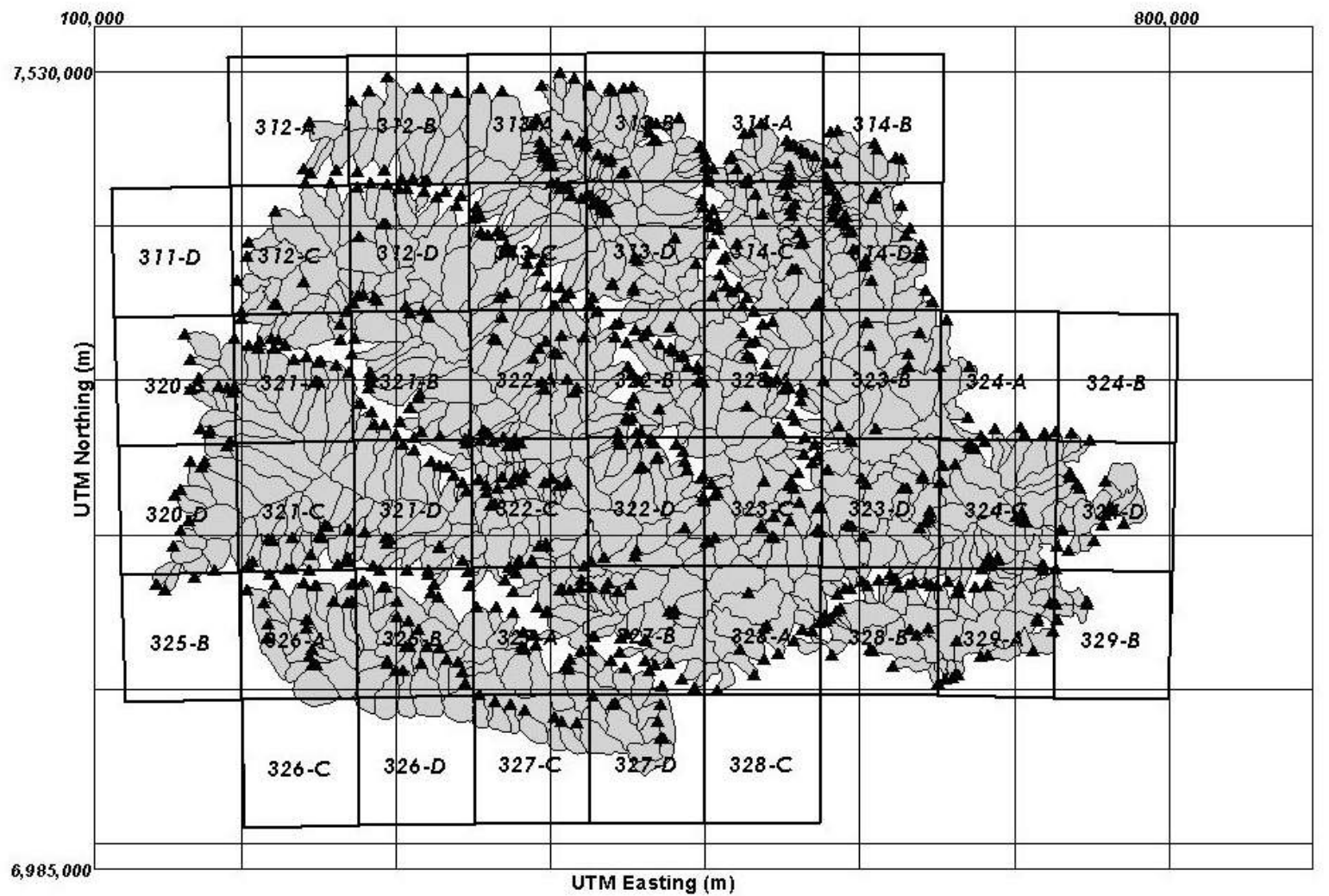

Figure 23

The 39 stream sediments composite samples for the GGRN sub-cells for the State of Parana. Each sub-cell has $45^{\prime}$ side, i.e., ca. $80 \mathrm{~km}$ in that latitude.

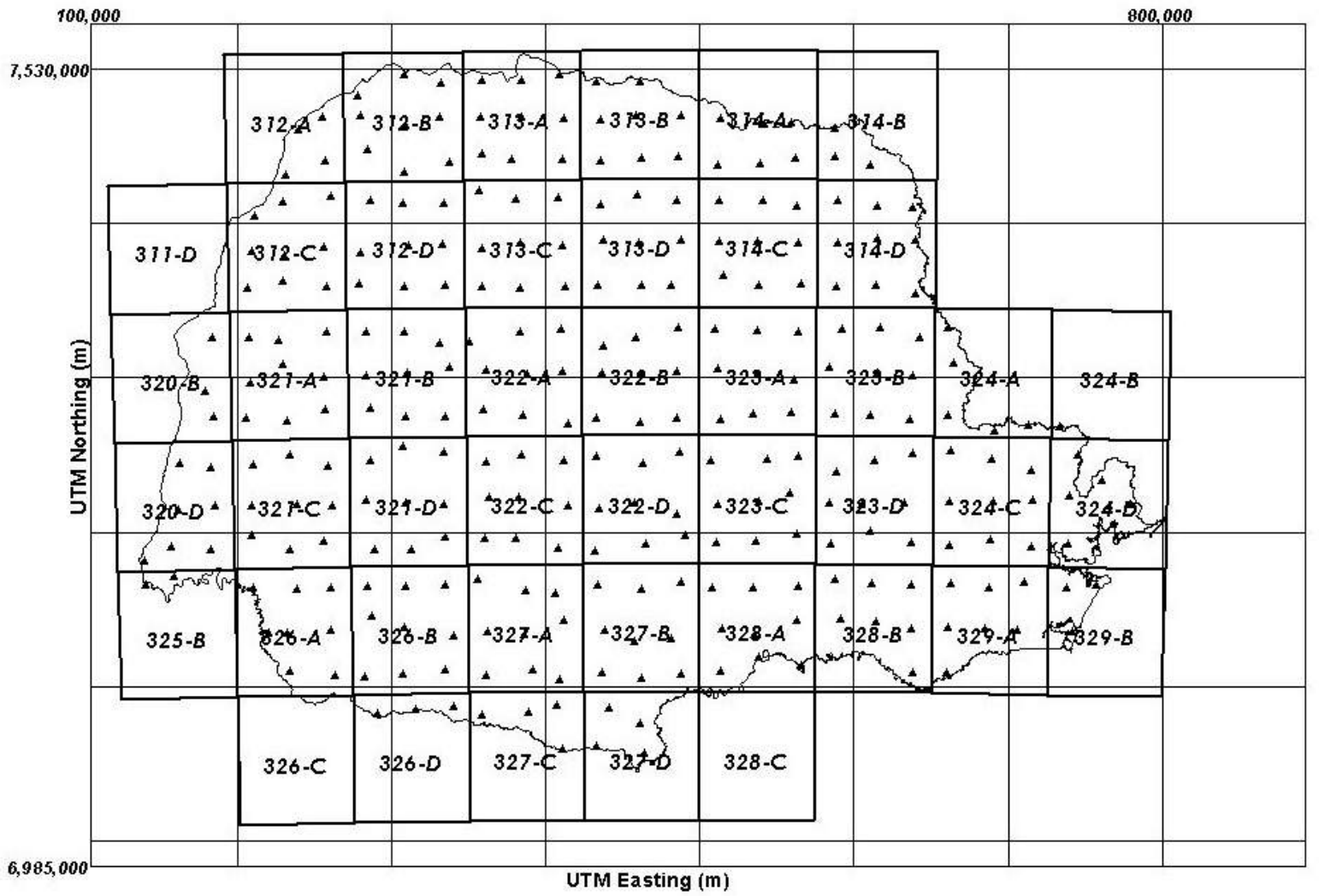

Figure 24

The 43 soil composite samples for the GGRN sub-cells for the State of Parana. Each sub-cell has $45^{\prime}$ side, i.e., ca. $80 \mathrm{~km}$ in that latitude. 
Table 7 - Summary of the analytical procedures applied by the Institute of Geophysical and Geochemical Exploration - IGGE laboratory, Langfang, P.R.China, to the stream sediments and soil - B horizon GGRN composite samples representing the State of Paraná.

\begin{tabular}{|c|c|c|c|}
\hline Sampled media & $\begin{array}{c}\text { GGRN } \\
\text { sub-cells }\end{array}$ & Laboratory & Element / oxide \\
\hline $\begin{array}{c}\text { Stream } \\
\text { sediment }\end{array}$ & 39 & \multirow{2}{*}{$\begin{array}{c}\text { Institute of Geophysical and } \\
\text { Geochemical Exploration - IGGE } \\
\text { Langfang, R.P.China }\end{array}$} & $\begin{array}{r}\mathrm{SiO}_{2}, \mathrm{Al}_{2} \mathrm{O}_{3}, \mathrm{Fe}_{2} \mathrm{O}_{3}, \mathrm{MgO}, \mathrm{CaO}, \mathrm{Na}_{2} \mathrm{O}, \\
\mathrm{K}_{2} \mathrm{O}, \mathrm{CO}_{2} \\
\mathrm{Ag}, \mathrm{As}, \mathrm{Au}, \mathrm{B}, \mathrm{Ba}, \mathrm{Be}, \mathrm{Bi}, \mathrm{Br}, \mathrm{Cd}, \mathrm{Ce}, \\
\mathrm{Cl}, \mathrm{Co}, \mathrm{C}_{\text {org }}, \mathrm{Cr}, \mathrm{Cs}, \mathrm{Cu}, \mathrm{Dy}, \mathrm{Er}, \mathrm{Eu}, \mathrm{F}, \\
\mathrm{Ga}, \mathrm{Gd}, \mathrm{Ge}, \mathrm{Hg}, \mathrm{Ho}, \mathrm{I}, \mathrm{La}, \mathrm{Li}, \mathrm{Lu}, \mathrm{Mn}, \\
\mathrm{Mo}, \mathrm{N}, \mathrm{Nb}, \mathrm{Nd}, \mathrm{Ni}, \mathrm{P}, \mathrm{Pb}, \mathrm{Pd}, \mathrm{Pr}, \mathrm{Pt} \\
\mathrm{Rb}, \mathrm{S}, \mathrm{Sb}, \mathrm{Sc}, \mathrm{Se}, \mathrm{Sm}, \mathrm{Sn}, \mathrm{Sr}, \mathrm{Tb}, \mathrm{Te} \\
\mathrm{Th}, \mathrm{Ti}, \mathrm{Tl}, \mathrm{Tm}, \mathrm{U}, \mathrm{V}, \mathrm{W}, \mathrm{Y}, \mathrm{Yb}, \mathrm{Zn}\end{array}$ \\
\hline $\begin{array}{c}\text { Soil } \\
\text { B horizon }\end{array}$ & 43 & & $\begin{array}{r}\mathrm{SiO}_{2}, \mathrm{Al}_{2} \mathrm{O}_{3}, \mathrm{Fe}_{2} \mathrm{O}_{3}, \mathrm{MgO}, \mathrm{CaO}, \mathrm{Na}_{2} \mathrm{O}, \\
\mathrm{K}_{2} \mathrm{O}, \mathrm{CO}_{2} \\
\mathrm{Ag}, \mathrm{As}, \mathrm{Au}, \mathrm{B}, \mathrm{Ba}, \mathrm{Be}, \mathrm{Bi}, \mathrm{Br}, \mathrm{Cd}, \mathrm{Ce}, \\
\mathrm{Cl}, \mathrm{Co}, \mathrm{C}_{\mathrm{org}}, \mathrm{Cr}, \mathrm{Cs}, \mathrm{Cu}, \mathrm{Dy}, \mathrm{Er}, \mathrm{F}, \mathrm{Ga}, \\
\mathrm{Gd}, \mathrm{Ge}, \mathrm{Hf}, \mathrm{Hg}, \mathrm{Ho}, \mathrm{I}, \mathrm{In}, \mathrm{La}, \mathrm{Li}, \mathrm{Lu}, \\
\mathrm{Mn}, \mathrm{Mo}, \mathrm{N}, \mathrm{Nb}, \mathrm{Nd}, \mathrm{Nd}, \mathrm{Ni}, \mathrm{P}, \mathrm{Pb}, \mathrm{Pd}, \\
\mathrm{Pr}, \mathrm{Pt}, \mathrm{Rb}, \mathrm{S}, \mathrm{Sb}, \mathrm{Sc}, \mathrm{Se}, \mathrm{Sm}, \mathrm{Sn}, \mathrm{Sr}, \\
\mathrm{Ta}, \mathrm{Tb}, \mathrm{Te}, \mathrm{Th}, \mathrm{Ti}, \mathrm{Tl}, \mathrm{Tm}, \mathrm{U}, \mathrm{V}, \mathrm{W}, \mathrm{Y}, \\
\mathrm{Yb}, \mathrm{Zn}, \mathrm{Zr}\end{array}$ \\
\hline
\end{tabular}

$$
w=\frac{1}{\left(1+\frac{d}{d_{0}}\right)^{2}} \quad \text { Equation } 1
$$

In order to produce the geochemical maps of the Geochemical Survey of the topographic sheet of Curitiba (see section 2.3.) and of the State of Paraná Low-density Geochemical Survey (see section 2.4.), the Ordinary Kriging was applied. In the first case, the 24 nearest points were sampled

in a search radius of $10,000 \mathrm{~m}$, to generate a final grid composed of 40,000 cells, each cell measuring $256 \mathrm{~m}$ in the $\mathrm{W}-\mathrm{E}$ direction and $281 \mathrm{~m}$ in the N-S direction. In the second case, the 24 nearest points were sampled in a search radius of $35,000 \mathrm{~m}$, to compose a final grid of 22,500 cells, each cell measuring $4,496 \mathrm{~m}$ in the $\mathrm{W}$-E direction and 3,350 $\mathrm{m}$ in the N-S direction.

For the other regional geochemical projects (see sections 2.5. and 2.6.), the geochemical surfaces were produced applying the multiquadric function, since it obeys the original data thus minimizing the residues, i.e., the differences between original and interpolated data. The smoothing parameter of the multiquadric function was selected case by case, as the mean value between the average sampling

\section{RESULTS AND DISCUSSION}

Despite the low sampling density, the geochemical mapping projects provided a clear overview of the distribution of the elements and also of the physicochemical parameters in river water and sediment and soils in the State of Paraná, portraying with fidelity the complex geochemical signatures originated from a geological background and modified by human-made processes. The complex database which was being gradually established spacing and the half of the average sampling spacing of the original samples (Carlson \& Foley 1991, apud Golden Software 2003).

The scale adopted to the class values considers the following percentile ranges: $5,15,25,40,50,65$, $75,85,90,91,93,95,97,99$ as well as the lowest and highest values for the data set, as adopted for the Finland (Koljonen et al. 1986) and the Great Britain (BGS 1991) geochemical atlases. This numerical scale has the property of stress either the geochemical relief and contrasts, compressing low values and highlighting high content areas. The color scale followed the principles of graphic semiology, with a color ramp ranging from deep gray and dark blue to represent the lowest contents to orange and red to represent the highest ones.

Other methodological details regarding the field, laboratory activities, data processing, geochemical mapping and the discussion of multipurpose applications for stream sediment and soil GGRN composite samples are discussed in Licht (2001a) and Licht \& Plawiak (2005), respectively. The main conclusions are summarized in section 3. Results and Discussion.

during the execution of the geochemical mapping program in several scales, with different sampling media and multi-element determined by highly sensitive analytical techniques, allowed to publish several articles in research journals and presented at international, national and regional scientific congresses and symposia as well (Licht \& Tarvainen 1996; Licht 2001a, 2001b, 2001c; Licht \& Plawiak 2005). The main results are summarized as follows. 


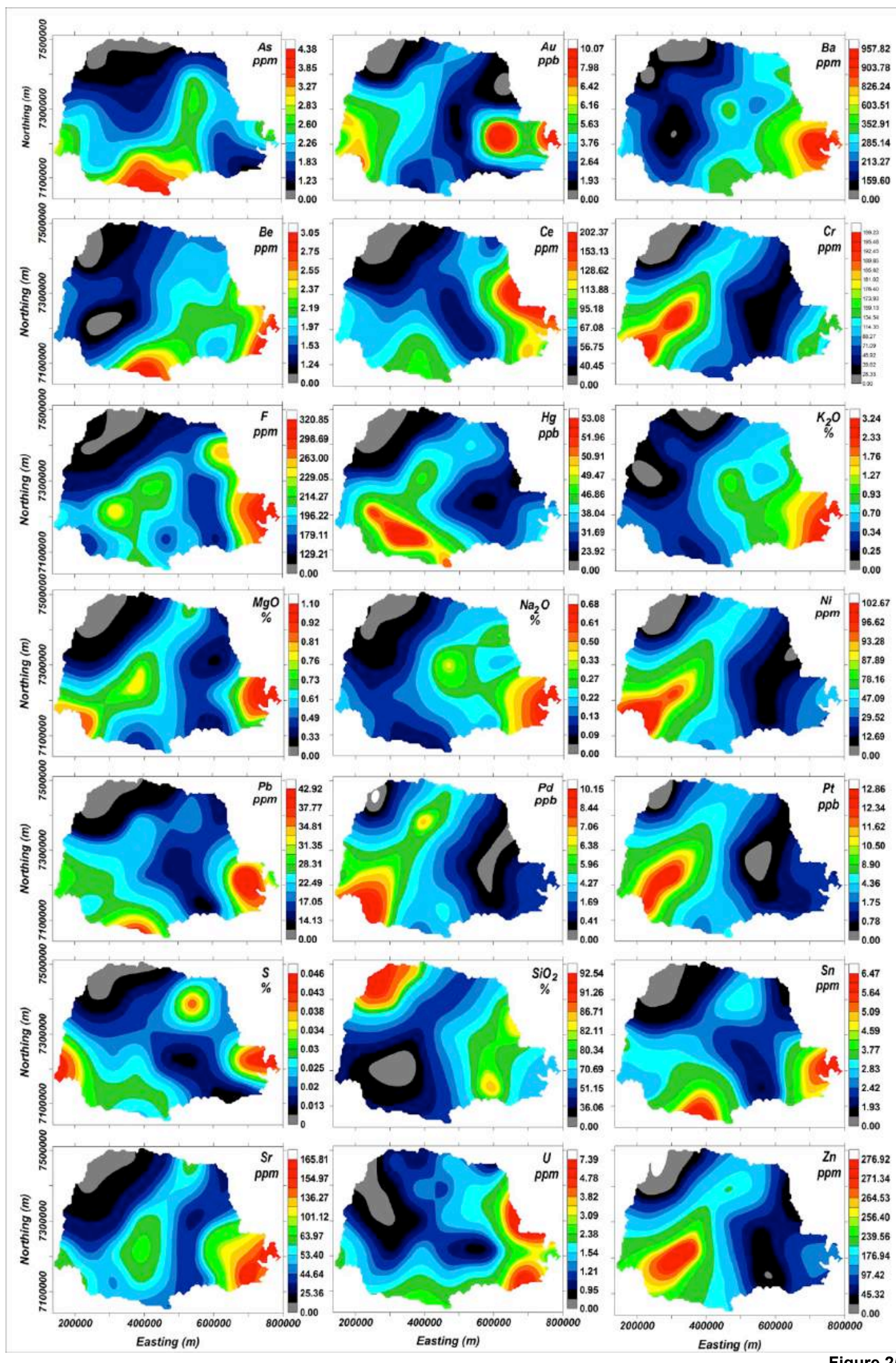

Figure 25

Geochemical maps showing the distribution of 24 selected elements analyzed in stream sediment composite samples representing GGRN sub-cells (see Table 7). 


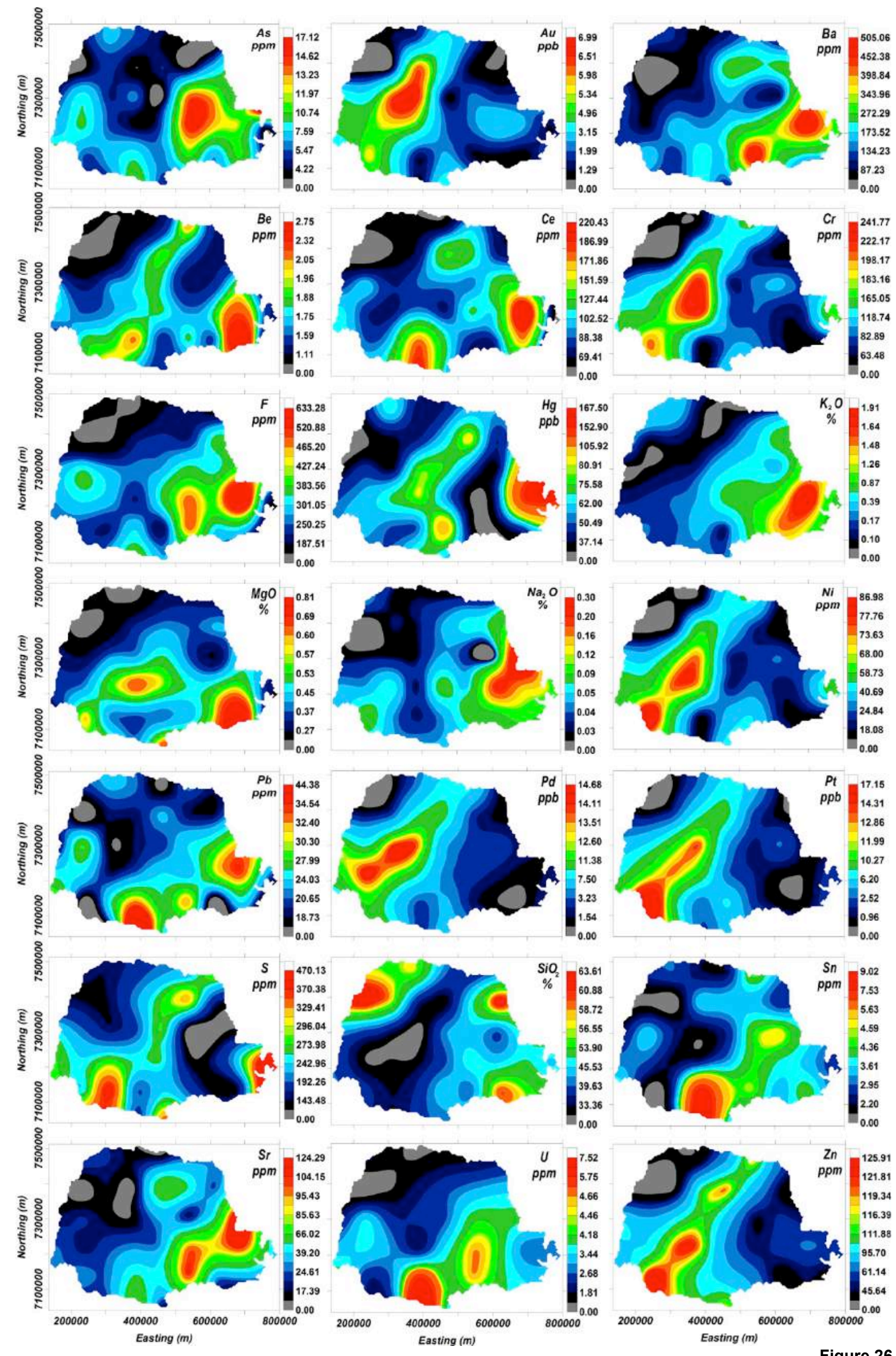

Figure 26

Geochemical maps showing the distribution of 24 selected elements analyzed in soil composite samples representing GGRN sub-cells (see Table 7). 


\subsection{GEOCHEMICAL FINGERPRINTS OF THE GEOLOGY AND OTHER NATURAL PROCESSES}

Geochemical fingerprints are characteristic associations of chemical elements in rocks, within mineralization or related to any natural process that develops in a geographical space.

The Coastal Plain is strongly influenced by the Atlantic Ocean, mangroves and marine aerosols, which overlap and contaminate continental waters from rivers and lagoons. High contents of $\mathrm{Br}^{-}-\mathrm{Cl}^{-}-$ $\mathrm{SO}_{4}{ }^{2-}-\mathrm{Ca}^{2+}-\mathrm{K}^{+}-\mathrm{Mg}^{2+}-\mathrm{Na}^{+}-\mathrm{Mn}^{2+}-\mathrm{Sr}^{2+}$ and electrical conductivity in stream waters, $\mathrm{Cl}^{-}$in stream sediments and $\mathrm{Br}-\mathrm{Cl}-\mathrm{I}-\mathrm{S}_{\text {extractable }}$ in soils reflect this marine - fluvial geochemical interface. High Al$\mathrm{B}-\mathrm{Ba}-\mathrm{Be}-\mathrm{F}-\mathrm{K}-\mathrm{Li}-\mathrm{Na}-\mathrm{Nb}-\mathrm{Pb}-\mathrm{Sn}-\mathrm{Th}$ contents in stream sediments and Al-B-Ba-K-Na-Si-W in soils markedly reflect the inheritance from granitic rocks, which constitute the geological background of the Coastal Plain as well as the source areas of Serra do Mar. On the other hand, high values of $\mathrm{Cr}-\mathrm{Mg}$ are found near ultramafic rocks such as norite, charnockite, kinzigite, $\mathrm{Mg}$ schists, amphibolite, meta-basic volcanics and meta pyroxenite of the Serra Negra Complex, located near the northern border with the State of São Paulo. High Cr-Mg contents are also detected in the Piên Complex on the southern border with the State of Santa Catarina. High $\mathrm{Al}_{\text {exchangeable- }}$ $\mathrm{Fe}_{\text {extractable }}$ contents indicate the intense ferralitic alteration and pedogenetic processes due to heavy rainfall and high average temperatures.

The First Plateau presents a hydrogeochemical landscape marked by high $\mathrm{F}^{-}$levels in the river waters that are mainly related to many fluorspar orebodies and showings that are found in the Ribeira river valley and also to the alkaline granitic intrusions. U-W-Zr and the majority of the REE - Ce, Er, Gd, Ho, La, Lu, Nd, Pr, Sm, Tb, $\mathrm{Tm}$ and $\mathrm{Yb}$ - as well are the main components in stream sediments of the First Plateau geochemical landscape, which express a multiple origin geochemical signature influenced by granitic rocks, Sn-Nb-W greisen, albitite and albitized granite, by the alkaline-carbonatite complexes, by many fluorspar bodies and showings. La-Nd carbonates hosted in the silty-clayey beds of the Guabirotuba Formation in the Curitiba Basin are also influencing this geochemical association. The geochemical signature of the soils from the First Plateau is similar, consisting of Si-Al-Mg-Na-BeB-Ba-K-Rb-Sr-Zr-La-Ce-Pr-Br-Cl-F-I-W-U-Th$\mathrm{K}-\mathrm{Th}$ and gamma total counts. This association also reflects the presence of granitic rocks, greisen and metasomatic processes and alkaline rocks accompanied by carbonatite. Another important geochemical signature of the First Plateau is formed by high As-Pb-Hg-Bi-Tl-Sb-Se contents, which correlates geographically to the wellknown $\mathrm{Pb}-\mathrm{Zn}$ mineralization of the Ribeira River Valley.

The geochemical landscape of the Second Plateau is characterized by geochemical signatures composed by a reduced number of elements, reflecting the predominantly siliciclastic Paleozoic sedimentary units of the Paraná Basin. They are well characterized by the elevation of the $\mathrm{Al}^{3+}$, which is directly correlated to low $\mathrm{pH}$ values measured in river waters, by the high $\mathrm{SiO}_{2}$ contents in stream sediments and by the association $\mathrm{Si}-\mathrm{Al}-\left(\mathrm{H}^{+}+\mathrm{Al}^{3+}\right)-\mathrm{Al}_{\text {exchangeable }}$ in soils. However, the chemical and clastic-chemical units belonging to the Paleozoic sedimentary rocks sedimentary are well defined by the association composed by $\mathrm{Ba}^{2+}-\mathrm{K}^{+}-\mathrm{Na}^{+}-\mathrm{Sr}^{2+}-\mathrm{Mg}^{2+}-\mathrm{Mn}^{2+}-\mathrm{Ca}^{2+}$ in river waters, $\mathrm{K}-\mathrm{Ba}$ in stream sediments and $\mathrm{Ba}-$ $\mathrm{B}-\mathrm{F}-\mathrm{K}$ in soil samples. The sedimentary rocks enriched in organic matter and containing coal seams, mainly those of the Passa Dois Group (Upper Permian), are well marked by high levels of $\mathrm{SO}_{4}{ }^{2-}$ in stream waters and by the association of C-U-eU-eTh-gamma spectrometry total counts in soils. The elevation of As contents mark the influence of carbonaceous shales and coal seams in stream sediments.

Based on the geological knowledge available at the time of execution of the geochemical surveys, the Third Plateau can be roughly divided into two main geological compartments: (a) acidic and basic volcanic rocks of the Serra Geral Group (Lower Cretaceous), which are partially covered by the (b) sedimentary sequence of the Bauru and Caiuá groups (Upper Cretaceous), both well characterized by typical geochemical associations. The acidic rocks (dacite, rhyodacite, and rhyolite) of the Serra Geral Group, exposed in the regions of Palmas and Guarapuava, are well delimited by low $\mathrm{Mg}^{2+}$ contents in stream waters as well as by the associations of high Al-As-Ba-Be-Bi-REE-Li$\mathrm{Mo}-\mathrm{Nb}-\mathrm{Pb}-\mathrm{Sb}-\mathrm{Sn}-\mathrm{Th}-\mathrm{Tl}-\mathrm{W}$ contents in stream sediments and high Ag-Al-As-Bi-Cd-REE-F-GaGe-Hf-Li-Mo-Nb-Pb-Sb-Sn-Ta-Th-W-Zr contents in soils. On the other hand, the robust association of $\mathrm{Ca}-\mathrm{Co}-\mathrm{Cu}-\mathrm{Fe}_{2} \mathrm{O}_{3}$-Mn-Ni-P-Pd-Pt-Sc-Ti-V-Zn in stream sediments and $\mathrm{Au}-\mathrm{Ca}-\mathrm{Co}-\mathrm{Cr}-\mathrm{Cu}-\mathrm{Fe}_{2} \mathrm{O}_{3}-$ $\mathrm{Mg}-\mathrm{Mn}-\mathrm{Ni}-\mathrm{P}-\mathrm{Pd}-\mathrm{Pt}-\mathrm{Sc}-\mathrm{Ti}-\mathrm{V}-\mathrm{Zn}$ in soil samples are consistent with the geochemical background and reflect the exposure of the basic volcanic rocks. Besides, in the central region of these basic volcanics, even higher contents and stronger geochemical gradients of these sets of elements is related to Low $\mathrm{Zr}-$-Low Ti-Low $\mathrm{P}$ tholeiitic flows. Otherwise, the association of high $\mathrm{K}^{+}-\mathrm{Ba}^{2+}$ 
contents in stream water and high $\mathrm{SiO}_{2}$ contents in stream sediments and soils are accurate geochemical indicators for the siliciclastic sedimentary rocks of the Bauru and Caiuá groups.

\subsection{IDENTIFICATION OF HIGH POTENTIAL AREAS FOR MINERAL EXPLORATION}

When the results of the low-density regional projects of multi-elementary geochemistry are examined from a mineral prospecting perspective, they provide indications to the exploratory potential and favorability. This statement is especially real when the distribution of some precious metals is examined in a geological environment traditionally regarded as low exploratory potential, such as the basic volcanic rocks of the Serra Geral Group (Parana-Etendeka Igneous Province). The geochemical gradients within this enormous geological compartment delimit a central portion that measures ca. 50,000 $\mathrm{km}^{2}$ and display an association of high $\mathrm{Au}-\mathrm{Cu}-\mathrm{Zn}$ Co-Ni-Ti-Fe-V-Cr-Pt-Pd contents in stream sediments and soils. This elemental association indicates an exploratory favorability for copper and precious metals (mainly to gold and platinum group metals) to this geological compartment. Additionally, this association is consistently repeated in geochemical data obtained in various sample media in a sampling density compatible

\subsection{ENVIRONMENTAL DIAGNOSTICS}

Human activity in urban, industrial and rural areas produces geochemical environmental impacts of high complexity, generated by scattered or local sources related to highly complex inputs, processes, and residues. Despite this, changes in the natural geochemical characteristics by human activity can be identified in diverse sampling media and scales (Licht \& Bittencourt, 2013). Some hydrogeochemical anomalies reflect the impact of human activities, given the extensive and intensive use of household and industrial products. Areas with dense human occupation (inhabitants $/ \mathrm{km}^{2}$ ) in the conurbation of Curitiba and neighboring cities, as well as in the cities of Cambará, Bandeirantes, Cornélio Procópio, Jataizinho, Londrina, Cambé, Rolândia, Arapongas, Mandaguari and Maringá, are stressed by a geochemical halo composed by high $\mathrm{Br}^{-}-\mathrm{Cl}^{-}-\mathrm{Ca}^{2+}-\mathrm{Mg}^{2+}-\mathrm{NO}_{3}^{-}-\mathrm{PO}_{4}{ }^{2-}$ contents in stream waters. The increase of $\mathrm{Cl}^{-}$contents in the urban environment is mostly associated with the water processing for human supply, chlorinated disinfectants and cleaning household agents (Figure 19). Fluorinated water for public supply, residues generated from tooth brushing with fluorinated toothpaste and other dental products constitute major sources of fluorine contamination with a regional survey scale. The chemostratigraphy of these volcanics shows that in the top of the sequence a thick set of compatibles rich tholeiitic basalts are found, to which higher contents of $\mathrm{Au}, \mathrm{Pt}$, and $\mathrm{Pd}$ (Figure 26) are associated (Licht 2018; Gomes et al. 2018).

The high $\mathrm{Au}$ contents present in stream sediments (Figure 25) and soils (Figure 26) in the Coastal Plain indicate the well-known gold mineralization which has been mined since the 16th century. High $\mathrm{Au}$ contents in the First Plateau are connected to the ancient gold mine of Ferraria, near Curitiba (Figure 25), to the underground gold mine near the city of Campo Largo which is operating since the 1990's, to the epithermal mineralization known near Castro and also to some ancient artisanal mining sites (garimpos) known to occur near Ouro Fino (Fine Gold) and Bateias (Gold Pans) near Curitiba, and Adrianópolis and Apiaí in the Ribeira river valley (Liccardo \& Cava 2006).

of surface waters. This is easily understood since fluorinated toothpaste contains up to $1,300 \mathrm{ppm} \mathrm{F}$ and the fluoridation of water for human consumption in the State of Paraná surpasses 120 tons $\mathrm{F} /$ year (Figure 19). Abnormal $\mathrm{Pb}$ contents coinciding with major urban centers and major roads in the Curitiba conurbation reflect an environmental stock that was originated by the consumption of fuels containing tetra-ethyl lead $\left[\mathrm{Pb}\left(\mathrm{C}_{2} \mathrm{H}_{5}\right)_{4}\right]$ until the 1990's (Figure 13 and Figure 16). In the same area, a broad $\mathrm{Hg}$ anomaly reflects the grand sum of urban pollution sources, mainly caused by lamps, anti-fungal paints, the now-banned mercury fungicides and improper waste disposal of some dentist offices. In the region situated between the cities of Ouro Fino and Bateias, not so far of the capital Curitiba, some $\mathrm{Hg}$ anomalies are possibly related to the mercury used by gold diggers ('garimpeiros') in the $18^{\text {th }}$ and $19^{\text {th }}$ centuries (Figure 16).

When the densely populated area of Curitiba is compared to the rural low-inhabited areas of its surroundings, it becomes evident the strong geochemical contrast between them, as shown in Table 8. 
Table 8 - Contrasts of selected elements between the densely populated area of Curitiba and its urban surroundings (Data from Licht 2001c).

\begin{tabular}{cccc}
\hline Analysed media & Element & $\begin{array}{c}\text { Curitiba } \\
\text { urban area }\end{array}$ & $\begin{array}{c}\text { Rural } \\
\text { surroundings }\end{array}$ \\
\hline & $\mathrm{Ba}(\mathrm{ppm})$ & 15 to 96 & $<10$ \\
$<80$ \# fraction of stream & $\mathrm{Cr}(\mathrm{ppm})$ & 1 to 20 & $<1$ \\
sediments; & $\mathrm{Fe}(\%)$ & 0.2 to 0.91 & 0.10 \\
AAS after EDTA 5\% digestion & $\mathrm{P}(\%)$ & 0.01 to 0.09 & $<0.005$ \\
& $\mathrm{~Pb}(\mathrm{ppm})$ & 9 to 123 & $<10$ \\
\hline$<80 \#$ fraction of stream & $\mathrm{Hg}(\mathrm{ppb})$ & 25 to 1,400 & $<25$ \\
sediments; & & & \\
AAS after hydride generation & &
\end{tabular}

In much more detail, river water and sediments may point out the geochemical influences overprinted by the central part of Umuarama on the natural environment. The geochemical impacts in stream sediments could be identified in river basins of up to $25 \mathrm{~km}^{2}$ and stream waters up to 10 $\mathrm{km}$ from the urban center, which means a catchment basin of $70 \mathrm{~km}^{2}$ (Figure 13).

Many elements showed high contrasts between the urban area of Umuarama and its rural surroundings, as identified in stream sediments, a quite stable and trustworthy sampling media (Table 9).

Table 9 - The contrast between the contents of selected elements analyzed in streams in the urban-industrial area of Umuarama and its rural surroundings (Data from Piekarz \& Ignacio 1995).

\begin{tabular}{cccc}
\hline Analysed media & Element & $\begin{array}{c}\text { Umuarama } \\
\text { urban area }\end{array}$ & $\begin{array}{c}\text { Rural } \\
\text { surroundings }\end{array}$ \\
\hline & $\mathrm{Al}(\%)$ & 4.39 & 0.31 \\
$<80 \#$ fraction of the stream & $\mathrm{As}(\mathrm{ppm})$ & 20 & $<5$ \\
sediments; & $\mathrm{Ba}(\mathrm{ppm})$ & 136 & 11 \\
atomic absorption, after aqua & $\mathrm{Cu}(\mathrm{ppm})$ & 119 & 3.6 \\
regia extraction & $\mathrm{Cr}(\mathrm{ppm})$ & 105 & 15 \\
& $\mathrm{Ni}(\mathrm{ppm})$ & 568 & 3.6 \\
& $\mathrm{~Pb}(\mathrm{ppm})$ & 20 & 2.3 \\
& $\mathrm{~V}(\mathrm{ppm})$ & 137 & 8.5 \\
\hline Evaporation residue of the & $\mathrm{Al}(\%)$ & 83.5 & 0.41 \\
stream water; & $\mathrm{As}(\mathrm{ppm})$ & 0.22 & 0.10 \\
atomic absorption, after aqua & $\mathrm{Ba}(\mathrm{ppm})$ & 1.10 & 0.31 \\
regia extraction & $\mathrm{Cu}(\mathrm{ppm})$ & 0.13 & 0.03 \\
& $\mathrm{Cr}(\mathrm{ppm})$ & 0.13 & 0.06 \\
& $\mathrm{Ni}(\mathrm{ppm})$ & 0.09 & 0.17 \\
\hline Filtered stream water, specific & $\mathrm{Pb}(\mathrm{ppm})$ & 0.41 & 0.02 \\
ion electrode & $\mathrm{V}(\mathrm{ppm})$ & 0.23 & 0.05 \\
\hline
\end{tabular}

The impacts generated by decades of agricultural activity are also stressed on the $\mathrm{Cl}^{-}$ map in stream waters. In the first half of the $20^{\text {th }}$ century, organic-chlorinated pesticides were continuously and intensively applied, mainly in coffee and cotton plantations. Thus, the residues of these products constitute an environmental stock which has been slowly decomposing and releasing its chemical components. Even though Brazilian agriculture legislation has banned the organic-chlorinated compounds, these organic molecules have high environmental persistence. The same applies to high $\mathrm{Br}^{-}$contents, which is likely related to the use of pesticides in cotton crops or the use of methyl bromide $\left(\mathrm{CH}_{3} \mathrm{Br}\right)$ on grain preservation. Following this rule of human impact, the river waters of the northern region of the State of Paraná show highly contrasted $\mathrm{Cl}^{-}$and $\mathrm{Br}^{-}$contents (Figure 19), coinciding with decades of coffee and cotton plantations (Figures 27a and 27b).

In the southwestern region of the State of Paraná, the river waters show high $\mathrm{NO}_{3}{ }^{-}$and $\mathrm{PO}_{4}{ }^{2-}$ contents, which could be easily associated to the release of phosphorus and nitrogen-rich organic waste generated by intense poultry and pig farming (Figure 19).

Alterations and impacts on the natural geochemical landscape by industrial plants play an important role in the release of large amounts of solid wastes, liquid effluents, suspended particulates, and gases. 


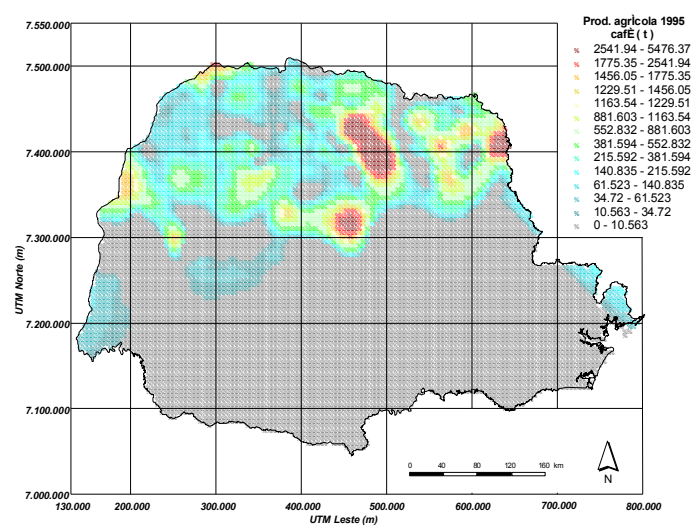

a

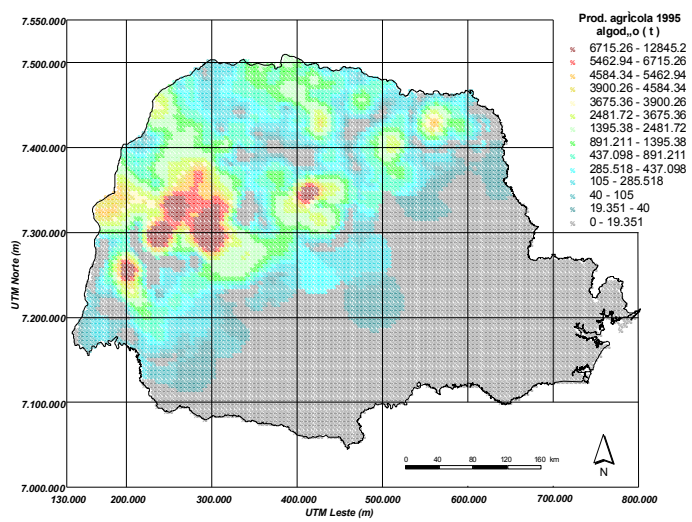

b

Figure 27

Distribution of (a) coffee and (b) cotton crops in 1995 in the State of Paraná (Licht 2001).

Coal is naturally enriched in various elements such as $\mathrm{Cd}, \mathrm{S}$, and $\mathrm{Fe}$ in the form of pyrite $\left(\mathrm{FeS}_{2}\right)$ and under weathering conditions, it releases large amounts of sulfate. The distribution map of $\mathrm{SO}_{4}{ }^{2-}$ in river water (Figure 19) and $S$ in stream sediments (Figure 25) and soils (Figure 26) shows an intense positive anomaly with a close geographical correlation with the coal belt that connects the cities of Figueira, Cambuí, Curiúva, Telemaco Borba and Joaquim Távora and where are found the occurrences, the economic deposits and the major coal mines.

The map of $\mathrm{Cd}$ distribution in stream sediments in the State of Paraná (Figure 20) presents a unique positive anomaly that coincides with the former Figueira thermoelectric energy plant, which has exclusively consumed local coal for years.

An intense hydrogeochemical $\mathrm{Ca}^{2+}$ anomaly located between the cities of Adrianópolis, Cerro Azul, Rio Branco do Sul and Curitiba is closely

\subsection{DELINEATION OF HUMAN HEALTH RISK AREAS}

One of the noblest applications of the geochemical mapping is associated with health and epidemiological data and the delineation and characterization of human or animal health risk areas. The interaction between seemingly unrelated sciences is known as Medical Geology. The set of elements and chemical compounds that occurs in nature or that are introduced in it the by human action may represent a risk due to its toxicity or to the scarcity of some macro- or micronutrients essential to life and health.

A well-known example of a disease that may be caused is fluorosis. Depending on the daily intake of fluorine, it may produce beneficial or adverse effects on the body. Insufficient ingestion of this element may cause high prevalence of related to the limestones and dolomites belt, which belongs to the Açungui Group. This region has undergone intensive mining, transportation, and processing (crushing, grinding, calcining and cement manufacturing) of calcitic limestones and dolomites, producing large quantities of cement and industrial or agricultural limes. Thus, despite a naturally enriched geological background, a significant and long-term human-made alteration produced a highly contrasted geochemical landscape whose $\mathrm{Ca}^{2+}$ contents can be measured in stream sediments (Figure 16).

The $>100 \mathrm{ppb} \mathrm{Hg}$ anomaly identified in soil samples collected on the Coastal Plain reflects the environmental liabilities whose origins are distant in time. It began in the second half of the $\mathrm{XVI}^{\text {th }}$ century, by the accumulation of amalgamation residues released by gold diggers ('garimpeiros') during their activity on gold placers and veins since the beginnings of the $\mathrm{XX}^{\text {th }}$ century (Figure 26).

dental caries, but when ingested at the recommended dosage, it inhibits the appearance of cavities. On the other hand, high levels of fluorine will cause fluorosis, a disease that mostly affects, in varying degrees, the teeth and bones of school-age children. A positive anomaly of $\mathrm{F}^{-}$in the water of catchment basins from the State of Paraná as large as $20,000 \mathrm{~km}^{2}$ is found in Norte Pioneiro region, which comprises cities like Figueira, Santo Antonio da Platina, and Itambaracá. This anomaly contains up to 0.96 $\mathrm{mg} . \mathrm{L}^{-1} \mathrm{~F}^{-}$, which is very close to the limit of human health risk (from 1.0 to $1.2 \mathrm{mg} . \mathrm{L}^{-1} \mathrm{~F}^{-}$) established by the World Health Organization (WHO). In this specific case, the $\mathrm{F}^{-}$ hydrogeochemical map (Figure 19) gave the 
warning and served as the starting point for the sanitary and epidemiological investigations, which have identified the prevalence of dental fluorosis (Figure 28) in more than 60\% of the school-age children population (Morita, Carrilho

Neto, and Licht, 1998; Carey et al., 2001). The origin of this large fluorine anomaly is linked to geological sources (Licht, 2001a; Licht et al., 2015).

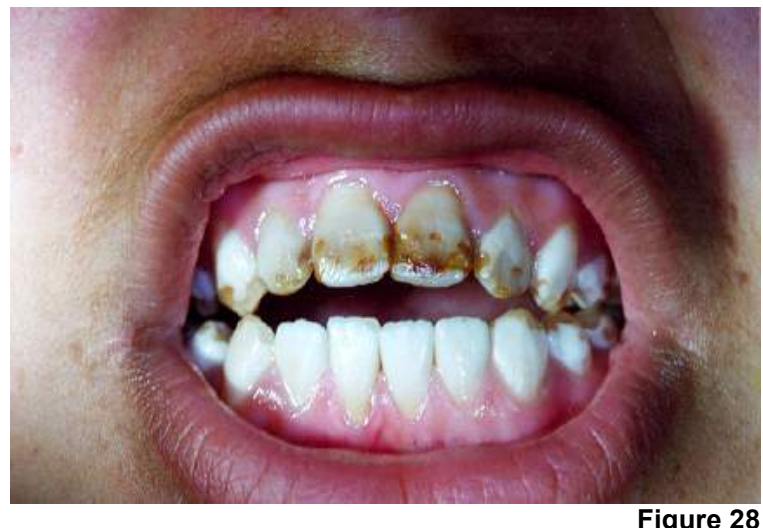

Figure 28

Severe dental fluorosis of an 11 years child which lives in a small village located inside the F- anomaly of the Norte Pioneiro region (Photo Maria Celeste Morita).

Other fluorine health risk areas identified in stream waters coincide with areas where dental fluorosis occurrences are known but not measured yet, e.g., in Castro, Marechal Cândido Rondon, Foz do Iguaçu, Nova Tebas, Bandeirantes, Figueira and Curiúva (Maria Celeste Morita pers. comm., 1999). It is clear, however, that not all of the identified $\mathrm{F}^{-}$positive anomalies represent health risk areas, as it may reflect residues containing high $\mathrm{F}^{-}$levels released by tooth brushing with fluorinated pastes, dentist offices and fluorinated water supply for human consumption, especially in highly populated regions.

The cause-effect relationship between high mortality rates by liver cancer with chlorinated and brominated pesticides used in coffee and cotton crops was identified by Marzochi et al. (1976). The mortality rate due to the liver and intrahepatic bile ducts per 100,000 inhabitants in 1997 was 2.137 in the Northern Brazilian region, 2.486 in the Northeast, 2.646 in the Midwest, 3.225 on the Southeast and up to 3.642 in the Southern (INCA, 2000). Even taking into consideration that there may be some problems in the process of death notifications in the less developed Brazilian regions, the geographically related growth on the mortality rates is compatible with the increase in agriculture. When compared with the data for the Brazilian regions, the ten municipalities with the highest mortality rates in the State of Paraná range from 7.47 in Rondon to 9.29 in São Pedro do Ivaí, showing a strong contrast from 2.05 to 2.55 times greater than the Southern Brazil index of 3.642 (Figure 29a). These cities with the highest mortality rates are located in the Northern part of the State of Paraná.
Historically, the North, Northwest and West parts of the State of Paraná concentrate intense and extensive cotton and coffee crops. The 1995-1996 census for the agriculture production estimates 181,626 hectares for cotton and 299,919 hectares for coffee plantation. For decades, large amounts of organochlorine pesticides such as BHC were employed in coffee farms, whereas chlorinated insecticides with bromine in the molecule of the active ingredient were broadly used in cotton crops, as could be noted in the Ordinance ${ }^{\circ} 10$ (08/03/ 1985) of the National Health Surveillance Secretariat, Health Ministry of Brazil.

The brominated and chlorinated active components have an environmental persistence that can last for decades (Flores et al. 2004). These compounds are currently under surveillance and forbidden, but in the past, they were indiscriminately used. In the course of the decomposition of such cumulative environmental stock, generated by the application of these products in the agriculture, the molecule components (including $\mathrm{Cl}^{-}$and $\mathrm{Br}^{-}$) are released to the environment. Distribution maps of $\mathrm{Cl}^{-}$and $\mathrm{Br}^{-}$ in river water catchment basins of the State of Paraná (Figure 19) show a large positive anomaly of both anions in the northern area of the state. Statistical and geographical treatment of geochemical, agricultural and epidemiological data has shown a consistent spatial correlation between them (Licht 2001a). In this way, and without measuring pesticide residues directly in river water samples, it was possible to characterize the $\mathrm{Cl}^{-}$and $\mathrm{Br}^{-}$as environmental risk indicators for International Disease Code IDC 10 malignant neoplasm of liver and intrahepatic bile ducts (Figures 29a and 29b). 


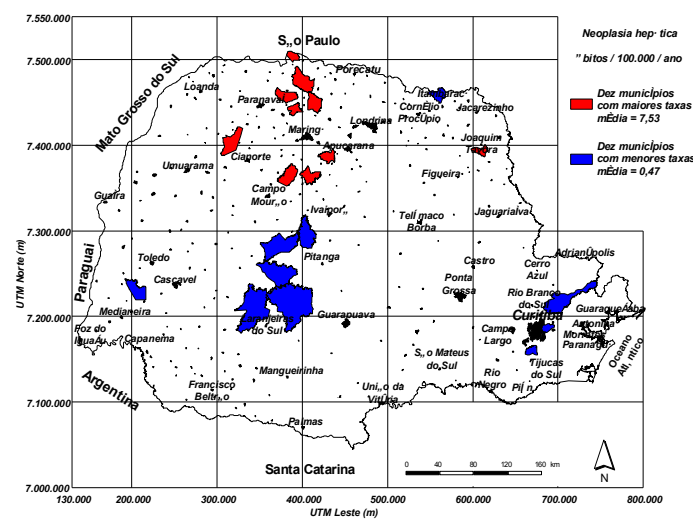

a

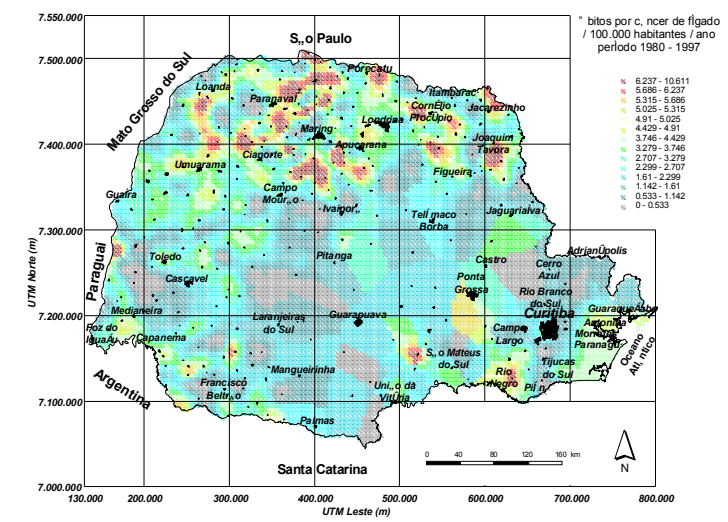

$\mathrm{b}$

Figure 29

(a) municipalities of the State of Paraná with the lowest mortality rates by liver cancer (blue polygons) against those with high mortality rates by the same disease (red polygons); (b) distribution of liver cancer in the state of Paraná. All data from DATASUS comprise the period from 1980 to 1997 (Licht 2001).

\subsection{GEOMEDICINA® PROJECT}

The causal relations observed between the geochemical data available for the State of Paraná and some diseases developed in this area were the first step for a team of doctors, statistics and computing experts from the Instituto de Pesquisa Pelé Pequeno Príncipe to start planning, designing and developing the Geomedicina ${ }^{\circledR}$ Project. This project aims to investigate the linkages and cause-and-effect relationships between environmental factors and the diseases that affect children and adolescents. Therefore, it was developed a web-mapping system for online consultation and operation, which allows statistical and geographical analysis of a diversified substrate of socio-economic, epidemiological and geochemical databases. The Geomedicine ${ }^{\circledR}$ Project has open access at http://geomedicina.org.br, http://geomedicina.pele pequenoprincipe.org.br or http://geomedicina. ippsys.org.

An important result of the Geomedicine ${ }^{\circledR}$ Project is the discovery of the causal relationship between congenital malformations and hydrogeochemistry (stream water) in the State of Paraná (Ibañez et al., 2018). The authors examined (a) the concentration of chlorine $\left(\mathrm{Cl}^{-}\right)$in waters associated with the presence of organochlorines and (b) the association between these chemicals and agricultural production with congenital malformations.

\subsection{ONLINE CONSULTATION OF REFERENCE VALUES}

With the aim of giving public access and consultation of the element contents and its spatial variability in the state of Paraná, an interactive web mapping system was designed and developed in 2017 by the teams of the Instituto de Terras, Cartografia e Geologia - ITCG and the Companhia de Processamento de Dados do

\section{FINAL REMARKS}

The geographical distribution of physicochemical variables determined in various sample media, such as river waters and sediments and soils (B horizon), shows large spatial heterogeneity, which depends on a lot of factors and origins. On the other hand, it is remarkable the influence played by the natural heritage, i.e.,
Paraná - CELEPAR. This system has a friendly interface, where it is possible for the user to select the sample medium and the element of interest and load the distribution map on the screen (Figure 30). The system has free access and is available at http://www.geoitcg.pr.gov.br/geoitcg/ pages/templates/initial_public.jsf?windowId=254

the geological background or the presence of mineral deposits and occurrences. However, the overprint influences displayed by land use, such as the location of urban centers, population density and, agriculture and husbandry, road network and the concentration of industrial units must be considered. Thus, the grand sum of these 


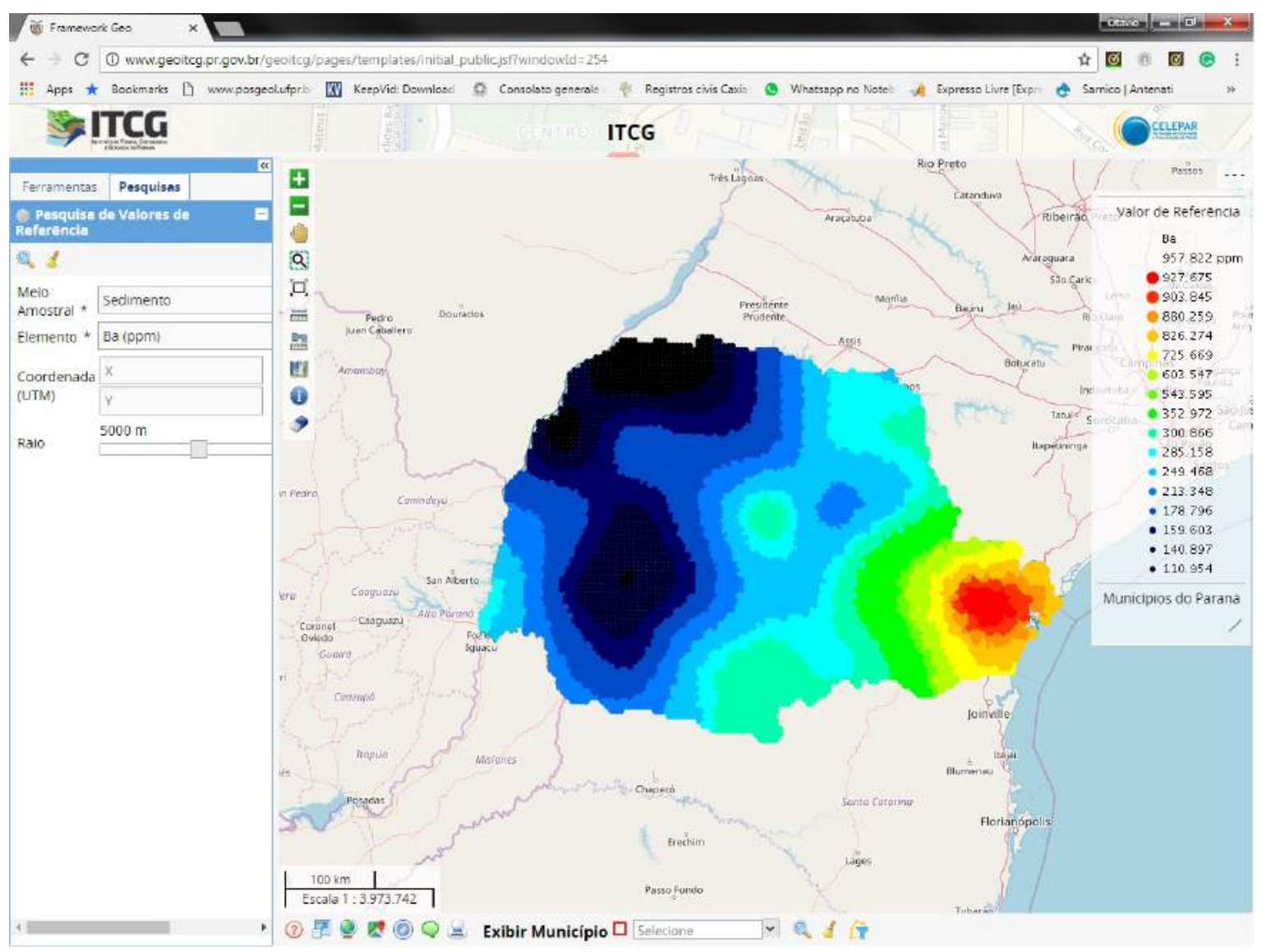

Figure 30

Screen of the ITCG's interactive web mapping system designed for online inspection of the geochemical reference values of the State of Paraná.

natural and anthropic sources constitutes the geochemical signal, i.e., the value of the variable obtained in any sample by laboratory analysis, which contributes to compose the spatial distribution patterns displayed in a geochemical map (Licht et al. 2006). The constitution of this robust geochemical database, based on stream water and sediment and soil (B-horizon) samples, allowed to establish reference levels for a large number of variables, which can be considered as initial milestones for other researches directed to deepen the knowledge on the distribution and availability of these elements in the State of Paraná. Comparing the tables presented in Licht et al. (2006) it is possible to identify a great coherence and consistency in the distribution of elements in various sample media, reflecting the representativeness of the sample collection procedures, the adequacy of the catchment basins size, the spacing between samples in regional surveys and the high quality of the analytical techniques to reach ultra-low detection limits, in particular for the trace and ultra-trace elements. It is of utmost importance to demonstrate that the elements and other certain variables are not evenly distributed across the territory as a large horizontal plane, but accordingly to a wavy surface, whose crests and valleys show the regional influences due to multiple factors coming from multiple sources. Therefore, it does not make any sense to establish reference values that represent a horizontal plane over such a vast territory as the State of Paraná, subjected to human occupation and natural influences that make it so geochemically complex. The results obtained with such a large amount of analytical variables measured in diverse sampling media show that the regional distribution of the analyzed variables is more properly represented through one surface adjusted to original values with geostatistical techniques.

In order to use the maps in an appropriate manner and to establish cause-effect relationships, the maps showing the distribution of the variables in the various sampling media must be associated with other channels of information such as the geology, the land use and occupation, and even the geographical distribution of endemic disease in flora, fauna and particularly in humans. The regional and detail surveys summarized in this article represent the geochemical reference to the State of Paraná territory and will serve as an initial milestone for new surveys and the composition of historical series.

From these marks, the investigations must proceed with: (a) the collection of stream 
water/sediment and soil (B horizon) samples, following increasingly dense grids that allow better spatial resolution; (b) collection and analysis of groundwater, other soil horizons and also rocks, following analytical techniques compatible with those that have already been applied and described; (c) determination of geochemical speciation which characterizes bioavailability, in order to amplify the scope of results in environmental, biological, sanitary and epidemiological investigations; (d) multimedia and multi-element surveys covering densely occupied urban areas, like the capital Curitiba and

\section{ACKNOWLEDGEMENTS}

Acknowledgements and recognition are due to a huge set of technicians and researchers from the following local, national and foreign research organizations: Minerais do Paraná S.A. / Serviço Geológico do Paraná - MINEROPAR, Instituto Paranaense de Assistência Técnica e Extensão Rural - EMATER-PR, Instituto Ambiental do Paraná - IAP, Institute of Geophysical and Geochemical Exploration - IGGE (R. P. China), Geological Survey of Finland - GSF, Serviço Geológico do Brasil - SGB/CPRM, Instituto Agronômico do Paraná - IAPAR/Londrina, Laboratório de Geofísica Aplicada LPGA/UFPR, Laboratório de Processamento de Informações Geo-referenciadas LAPIG/UNICAMP, Laboratório de Solos da Universidade Estadual de Maringá - UEM, Departamento de Odontologia da Universidade

\section{REFERENCES}

Cardoso L. M., Morita M. C., Licht O. A. B., Alves, J. C. 2001. Anomalia hidrogeoquímica e a ocorrência de fluorose dentária em Itambaracá - PR.. In: VIII Congresso Brasileiro de geoquímica e I Simpósio de Geoquímica dos Países do MERCOSUL, 2001, Curitiba. Anais do I CBGq. Rio de Janeiro: Sociedade Brasileira de Geoquímica, 2001.

Darnley A. G., Björklund A., Bølviken B., Gustavsson N., Koval P. V., Plant J. A., Steenfelt A., Tauchid M., Xuejing X. 1995. A global geochemical database for environmental and resource management: recommendations for international geochemical mapping. Paris, Unesco. Final Report of IGCP Project 259. Available http://unesdoc.unesco.org/images/0010/001010/101 010eo.pdf. Access February 2018

Figueiredo B.R., Litter M..I., Silva C.R., Mañay N., Londono S.C. Rojas A.M., Garzón, C. Tosiani T., Di Giulio G.M., De Capitani E.M., Dos Anjos J.A.S.A., Angélica R.S., Morita M.C., Paoliello M.M.B., Cunha F.G., Licht O.A.B. 2010. Medical Geology Studies in South America. In: SELINUS, its surroundings, and the Londrina and Maringá conurbations as well.

Samples of all geochemical surveys described in this article, including river sediment and soil samples, as well as the frozen stream water samples, are appropriately stored in the ITCG laboratory. They compose an important scientific collection that serves as a reference to establish a historical series of the geochemical characteristics of the State of Paraná's territory.

All geochemical databases are available and downloadable at http://www.mineropar.pr.gov.br/ modules/conteudo/conteudo.php? conteudo $=6$

Estadual de Londrina - UEL, Hospital Erasto Gaertner, Laboratório Central da Secretaria da Saúde do Paraná - SESA, Instituto de Pesquisas Pelé Pequeno Príncipe - IPPP, Secretaria da Ciência e Tecnologia do Paraná - SETI, Fundação Araucária, Companhia de Tecnologia da Informação e Comunicação do Paraná CELEPAR, Empresa Brasileira de Pesquisa Agropecuária - EMBRAPA Solos, Steering Commitee, International Geological Correlation Program - IGCP 360 for directly or indirectly participating in the various stages of geochemical mapping projects in the State of Paraná. The reviewers Xieqiu Wang and Jorge de Lena are acknowledged for the critical reading and the suggestions made to improve the manuscript. Daianne Höfig and Allan da Silva Gomes are acknowledged for the language improvement.

O., FINKELMAN, R.B., CENTENO, J.A.. (orgs.). Medical Geology - A Regional Synthesis. 1ed.: Springer Verlag, p.: 79-106.

Flores A.V., Ribeiro J.N., Neves A.A., Queiroz E.L.R. de 2004. Organoclorados: um problema de saúde pública. Ambiente \& Sociedade, VII ( 2):111-124.

Golden Software Inc. 2003. Surfer v 8.04 - Reference manual. Golden, Golden Software.

Gripp, M.L.R. 2012. Indicação geoquímica de desenvolvimento urbano-industrial em cidade portuária (Rio Grande - RS). Master Thesis. Programa de Pós Graduação em Oceanografia Física, Química e Geológica, Universidade Federal de Rio Grande, Rio Grande.

IAPAR - INSTITUTO AGRONÔMICO DO PARANÁ 1994. Cartas climáticas do Estado do Paraná. In: CORREA A. R. (Org.) Londrina, IAPAR. (Documento 18).

Ibañez H.C., Melanda V.S.,Viviane K.Q., Gerber V.K.Q., Licht O.A.B., Ibañez M.V.C., Aguiar Júnior T.R., Mello R.G., Komechen H., Andrade D.P., Picharski G.L., Figueiredo D.P.G., Pianovski 
M.A.D., Figueiredo M. M.O., Custódio G., Parise I.Z.S., Castilho L.M., Paraizo M.M., Edinger C., Fiori C.M.C.M., Pedrini H., Kiesel Filho N., Fabro A.L.M.R., Fachin R.D., Ogradowski K.R.P., Parise G.A., Saldiva P.H.N., Legal E.F., Rosati R., Rodriguez-Galindo C., Ribeiro R.C., Zambetti G.P., Lalli E., Figueiredo B.C. 2018. Spatial trends in congenital malformations and stream water chemistry in Southern Brazil. Science of Total Environment. 650:1278-1291.

ITCF - INSTITUTO DE TERRAS, CARTOGRAFIA E FLORESTAS 1987. Atlas do Estado do Paraná. Curitiba, ITCF / DIOE.

INCA - INSTITUTO NACIONAL DO CANCER, 2000. Available http://www.inca.org.br. Acess 2001.

Larach J. O. I., Cardoso A., Carvalho A. P. de, Hochmüller D. P., Martins J. S., Rauen M. de J., Fasolo P. J., Pötter R. O. 1984. Levantamento de reconhecimento de solos do Estado do Paraná. Londrina: IAPAR; Curitiba: EMBRAPA-SNLCS 1984. EMBRAPA-SNLCS. Boletim de pesquisa, $n$. 27; IAPAR-Projeto Especial Levantamento de Solos. Boletim técnico, n. 16. Map color. scale 1:600.000.

Liccardo A., Cava, L.T. 2006. Minas do Paraná. Curitiba, Minerais do Paraná. S.A., 1ed. 163p.

Licht O.A.B. 2001a. A geoquímica multielemental na gestão ambiental. Identificação e caracterização de províncias geoquímicas naturais, alterações antrópicas da paisagem, áreas favoráveis à prospecção mineral e regiões de risco para a saúde no Estado do Paraná, Brasil. Doctor Thesis. Dept. de Geologia, Univ. Federal Paraná, Curitiba. Available http://acervodigital.ufpr.br/handle/1884/41646.

Licht O.A.B. 2001b. Atlas geoquímico do Estado do Paraná. 1. ed. Curitiba: Minerais do Paraná S.A. MINEROPAR., v. 1. 71p. Available at www.mineropar.pr.gov.br/arquivos/File/publicacoe s/Atlas_geoquimico_PR.pdf

Licht O.A.B. 2001c. Attlas geoquímico da Folha Curitiba. 1. ed. Curitiba: Minerais do Paraná S.A. MINEROPAR., v. 1. 67p. Available at www.mineropar.pr.gov.br/arquivos/File/publicacoe s/Atlas_geoquimico_curitiba.PDF

Licht O.A.B. 2005. Human Health Risk Areas in the State of Parana, Brazil - Results from Low Density Geochemical Mapping. Terræ. Geosciences, Geography and the Environment (Online), Campinas, São Paulo, v. 2, n.1, p. 9-19. Available at https://www.ige.unicamp.br/terrae/V1/ PDFN1/terrae_2005_v02n01-02_p09-19_licht.pdf

Licht O.A.B. \& Plawiak R.A.B. 2005. Geoquímica de Solo do Paraná - horizonte B. Curitiba, Mineropar. 2 v. 740 p. Available at http://www.mineropar.pr.gov.br/arquivos/File/ publicacoes/relatorios_concluidos/ 12_1_relatorios_concluidos.pdf
Licht O.A.B., Piekarz G.F., Silva J.C.C., Lopes Jr I. 1997. Levantamento geoquímico multielementar de baixa densidade no estado do Paraná hidrogeoquímica - resultados preliminares. A Terra em Revista - Revista técnica informativa da CPRM, Rio de Janeiro, v. III, n.3, p. 34-46.

Licht O.A.B. \& Tarvainen T. 1996. Multipurpose geochemical maps produced by integration of geochemical exploration datasets in The Paraná Shield, Brazil. Journal of Geoch. Explor 56(3):167182.

Licht O.A.B., Xuejing X., Qin Z., Miyazawa M., Ferreira F.J.F., Plawiak, R.A.B. 2006. Average reference values of geochemical and geophysical variables in stream sediments and soils, State of Paraná, Brazil. Boletim Paranaense de Geociências, n. 58, p. 59-87. Editora UFPR. Available at http://revistas.ufpr.br/geociencias/article/view/10714/7 117

Licht O.A.B., Bittencourt A.V.L. 2013. Paisagens geoquímicas - naturais e antrópicas - no Estado do Paraná. Revista Técnico-Científica do CREA-PR, v. 1, p. 1-27. Available at http://creaprw16.creapr.org.br/revista/Sistema/index.php/revista/issue/view/ 1/showToc

Maack R. 1968. Geografia física do Estado do Paraná. Curitiba, Badep / UFPR / IBPT.

Marzochi M.C.A., Coelho R.B., Soares D.A., Zeitune J.M.R., Muarrek F.J., Cecchini R., Passos E.M. 1976. Carcinogênese hepática no norte do Paraná e uso indiscriminado de defensivos agrícolas. Ciência e Cultura, São Paulo, 28 (8): 893-901

MINEROPAR - MINERAIS DO PARANÁ S.A. 1986. Mapa geológico do Estado do Paraná. Curitiba, Mineropar $\quad 1: 1,400,000$ Available http://www.mineropar.pr.gov.br/modules/conteudo/co nteudo.php? conteudo=22. Access March 2018

Morita M.C., Carrilho A., Licht O.A.B. 1998. Use of geochemistry data in the identification of endemic fluorosis areas.. In: 1st. World Congress of Health in Urban Environment., 1998, Madrid. Proc. 1st. World Congress of Health in Urban Environment.. Madrid, 1998. p. 244.

Schacklette K. \& Boerngen J. 1984. Element concentrations in soil and other surficial material of the conterminous United States. USGS Prof. Paper 1720 .

Sergeev E.A. 1941 Geochemical method of prospecting for ore deposits. Materialy Vsesoiuznogo NauchnoIssledovale'skogo Geologicheskogo Instituta, Geofizika. Sbornik 9-10, st.3-55. Trad. V.P. Sokoloff. In "Selected Russian papers on geochemical prospecting for ores" U.S. Geol. Survey, p. 15-87. Feb. 1950

Smith D.B., Xueqiu Wang, Shaun R., Demetriades A., 2012. The IUGS/IAGC Task Group on Global Geochemical Baselines. Earh Science Frontiers, 19(3): $1-6$.

Smith D.B.,Demetriades A., de Caritat P., Xueqiu Wang, 2018. The history, progress, and future of global-scale geochemical mapping. Geochimica Brasiliensis (this Special Issue) 
Table A - Statistical estimates for the geochemical variables analyzed in the stream sediment samples of the Geochemical Survey of the topographic sheet of Curitiba (Licht 2001c).

\begin{tabular}{|c|c|c|c|c|c|c|c|c|c|}
\hline $\begin{array}{l}\text { Element } \\
\text { (unit) }\end{array}$ & Valid N & Minimum & $1^{\text {st }}$ quartile & Median & $\begin{array}{c}\text { Arithmetic } \\
\text { mean }\end{array}$ & $3^{\text {rd }}$ quartile & Maximum & Variance & $\begin{array}{c}\text { Standard } \\
\text { deviation }\end{array}$ \\
\hline $\mathrm{Al}(\%)$ & 351 & 0.02 & 0.08 & 0.13 & 0.224 & 0.29 & 1.73 & 0.0667 & 0.25826 \\
\hline As (ppm) & 351 & 2.5 & 2.5 & 2.5 & 3.34 & 2.5 & 12.0 & 4.18 & 2.04450 \\
\hline $\mathrm{Ba}(\mathrm{ppm})$ & 351 & 1.5 & 4.6 & 6.7 & 10.03 & 10.0 & 96.0 & 124.60 & 11.16243 \\
\hline $\mathrm{Ca}(\%)$ & 351 & 0.005 & 0.06 & 0.10 & 0.157 & 0.17 & 1.64 & 0.034 & 0.18439 \\
\hline Co (ppm) & 351 & 0.5 & 2.4 & 4.2 & 6.05 & 8.5 & 49.0 & 30.27 & 5.50181 \\
\hline $\mathrm{Cr}(\mathrm{ppm})$ & 351 & 0.5 & 0.5 & 0.5 & 0.756 & 0.5 & 20.0 & 4.964 & 70.45565 \\
\hline $\mathrm{Cu}(\mathrm{ppm})$ & 351 & 0.25 & 2.0 & 3.9 & 5.06 & 6.4 & 35.0 & 19.945 & 141.22676 \\
\hline $\mathrm{F}(\mathrm{ppm})$ & 363 & 42.0 & 480.0 & 260.0 & 322.69 & 420.0 & 1150.0 & 42433.66 & 205.99432 \\
\hline $\mathrm{Fe}(\%)$ & 351 & 0.02 & 0.08 & 0.11 & 0.139 & 0.16 & 0.91 & 0.0102 & 0.10099 \\
\hline $\mathrm{Hg}(\mathrm{ppb})$ & 362 & 25.0 & 25.0 & 25.0 & 38.95 & 25.0 & 1400.0 & 12118.01 & 110.08183 \\
\hline $\mathrm{K}(\%)$ & 351 & 0.005 & 0.005 & 0.005 & 0.0117 & 0.01 & 0.10 & 0.00017 & 0.01303 \\
\hline $\mathrm{La}(\mathrm{ppm})$ & 351 & 2.5 & 5.8 & 8.6 & 12.74 & 15.0 & 175.0 & 197.53 & 14.05453 \\
\hline $\mathrm{Li}(\mathrm{ppm})$ & 351 & 0.5 & 0.5 & 0.5 & 1.733 & 0.5 & 133.0 & 63.66 & 7.97872 \\
\hline $\mathrm{Mg}(\%)$ & 351 & 0.005 & 0.01 & 0.02 & 0.039 & 0.04 & 0.38 & 0.0031 & 0.05567 \\
\hline Mn (\%) & 351 & 0.005 & 0.02 & 0.03 & 0.055 & 0.077 & 0.65 & 0.0037 & 0.06082 \\
\hline $\mathrm{Na}(\%)$ & 327 & 0.98 & 1.06 & 1.07 & 1.074 & 1.09 & 1.16 & 0.0008 & 0.02828 \\
\hline $\mathrm{Nb}(\mathrm{ppm})$ & 357 & 2.5 & 22.0 & 31.0 & 36.945 & 46.0 & 238.0 & 642.338 & 801.45991 \\
\hline $\mathrm{Ni}(\mathrm{ppm})$ & 351 & 1.0 & 1.0 & 1.0 & 2.016 & 2.7 & 12.0 & 2.677 & 51.73973 \\
\hline $\mathrm{P}(\%)$ & 351 & 0.005 & 0.005 & 0.005 & 0.006 & 0.005 & 0.090 & 0.00004 & 0.00632 \\
\hline $\mathrm{Pb}(\mathrm{ppm})$ & 351 & 1.0 & 3.9 & 5.2 & 70.7 & 7.4 & 123.0 & 88.135 & 296.87539 \\
\hline $\mathrm{Sb}(\mathrm{ppm})$ & 351 & 2.5 & 2.5 & 2.5 & 2.516 & 2.5 & 5.4 & 0.0446 & 0.21118 \\
\hline Sc (ppm) & 351 & 0.5 & 0.5 & 0.5 & 0.96 & 1.3 & 5.9 & 0.566 & 0.75232 \\
\hline Sn (ppm) & 335 & 2.5 & 2.5 & 2.5 & 3.531 & 2.5 & 106.0 & 46.545 & 215.74290 \\
\hline $\mathrm{Sr}(\mathrm{ppm})$ & 351 & 0.25 & 0.6 & 1.3 & 3.267 & 3.4 & 85.0 & 48.192 & 219.52676 \\
\hline $\mathrm{Ti}(\%)$ & 351 & 0.005 & 0.005 & 0.005 & 0.005 & 0.005 & 0.02 & 0.000001 & 0.001 \\
\hline $\mathrm{V}(\mathrm{ppm})$ & 351 & 2.5 & 2.5 & 2.5 & 3.798 & 5.2 & 16.0 & 6.327 & 79.54244 \\
\hline $\mathrm{W}(\mathrm{ppm})$ & 351 & 5.0 & 5.0 & 5.0 & 5.895 & 5.0 & 14.0 & 5.0202 & 224.05802 \\
\hline $\mathrm{Y}(\mathrm{ppm})$ & 351 & 0.5 & 1.7 & 2.5 & 3.689 & 4.2 & 69.0 & 21.62 & 4.64973 \\
\hline $\mathrm{Zn}(\mathrm{ppm})$ & 351 & 0.5 & 4.4 & 6.4 & 9.258 & 9.9 & 158.0 & 173.389 & 416.40004 \\
\hline $\mathrm{Zr}(\mathrm{ppm})$ & 363 & 90.0 & 279.0 & 452.0 & 1143.19 & 1104.0 & 20300.0 & 4277972 & 2068.32589 \\
\hline
\end{tabular}

Note: details on the analytical techniques are referred on section 2.3.

Table B - Statistical estimates for the geochemical variables analyzed in filtered stream water samples of the State of Paraná Lowdensity Geochemical Survey (Licht 2001b).

\begin{tabular}{|c|c|c|c|c|c|c|c|c|c|}
\hline Ion / parameter (unit) & Valid N & $\begin{array}{l}\text { Minimum } \\
\text { value }\end{array}$ & $1^{\text {st }}$ quartile & Median & Arithmetic mean & $3^{\text {rd }}$ quartile & $\begin{array}{l}\text { Maximum } \\
\text { value }\end{array}$ & Variance & $\begin{array}{c}\text { Standard } \\
\text { deviation }\end{array}$ \\
\hline $\mathrm{Al}^{3+}\left(\mathrm{mg} \cdot \mathrm{L}^{-1}\right)$ & 697 & 0.02 & 0.125 & 0.125 & 0.173 & 0.125 & 3.86 & 0.876 & 0.93595 \\
\hline $\mathrm{Ba}^{2+}\left(\mathrm{mg} \cdot \mathrm{L}^{-1}\right)$ & 697 & 0.007 & 0.025 & 0.025 & 0.035 & 0.025 & 0.27 & 0.0102 & 0.10100 \\
\hline $\operatorname{Br}^{-}\left(m g \cdot L^{-1}\right)$ & 627 & 0.01 & 0.01 & 0.02 & 0.048 & 0.03 & 8.5 & 0.172 & 0.41473 \\
\hline $\mathrm{Ca}^{2+}\left(\mathrm{mg} \cdot \mathrm{L}^{-1}\right)$ & 697 & 0.1 & 2.3 & 3.81 & 6.005 & 7.14 & 48.61 & 39.803 & 199.50689 \\
\hline $\mathrm{Cl}^{-}\left(\mathrm{mg} \cdot \mathrm{L}^{-1}\right)$ & 697 & 0.008 & 0.43 & 0.8 & 7.72 & 1.5 & 2530.0 & 13909.61 & 117.93901 \\
\hline $\mathrm{Sr}^{2+}\left(\mathrm{mg} \cdot \mathrm{L}^{-1}\right)$ & 697 & 0.006 & 0.02 & 0.03 & 0.43 & 0.05 & 0.7 & 0.0025 & 0.05000 \\
\hline $\mathrm{Fe}^{3+}\left(\mathrm{mg} \cdot \mathrm{L}^{-1}\right)$ & 697 & 0.01 & 0.01 & 0.04 & 0.105 & 0.130 & 2.35 & 0.0349 & 0.18682 \\
\hline $\mathrm{F}^{-}\left(\mathrm{mg} \cdot \mathrm{L}^{-1}\right)$ & 694 & 0.001 & 0.01 & 0.0275 & 0.0526 & 0.06 & 0.98 & 0.0064 & 0.08000 \\
\hline $\mathrm{Mg}^{2+}\left(\mathrm{mg} \cdot \mathrm{L}^{-1}\right)$ & 697 & 0.025 & 1.21 & 1.81 & 30.2 & 3.28 & 159.3 & 56.679 & 238.07352 \\
\hline $\mathrm{Mn}^{2+}\left(\mathrm{mg}^{-\mathrm{L}^{-1}}\right)$ & 697 & 0.001 & 0.01 & 0.01 & 0.026 & 0.01 & 1.44 & 0.0086 & 0.09274 \\
\hline $\mathrm{NO}_{3}^{-}\left(\mathrm{mg} \cdot \mathrm{L}^{-1}\right)$ & 694 & 0.01 & 0.58 & 1.3 & 2.032 & 2.5 & 32.4 & 6.02 & 2.45357 \\
\hline $\mathrm{NO}_{2}^{-}\left(\mathrm{mg} \cdot \mathrm{L}^{-1}\right)$ & 541 & 0.01 & 0.01 & 0.01 & 0.014 & 0.01 & 0.23 & 0.00019 & 0.01378 \\
\hline $\mathrm{K}^{+}\left(\mathrm{mg} \cdot \mathrm{L}^{-1}\right)$ & 697 & 0.05 & 0.6 & 0.89 & 1.331 & 0.6 & 102.6 & 18.657 & 136.59063 \\
\hline $\mathrm{Na}^{+}\left(\mathrm{mg} \cdot \mathrm{L}^{-1}\right)$ & 697 & 0.125 & 1.01 & 1.68 & 5.672 & 2.83 & 1244.0 & 3381.76 & 58.15290 \\
\hline $\mathrm{SO}_{2}^{2-}\left(\mathrm{mg}^{2-1} \mathrm{~L}^{-1}\right)$ & 694 & 0.01 & 0.14 & 0.35 & 1.945 & 0.71 & 330.0 & 304.89 & 17.46110 \\
\hline $\mathrm{pH}$ & 697 & 3.30 & 6.30 & 6.70 & 6.59 & 6.90 & 7.7 & 0.168 & 0.40988 \\
\hline E.C. $(\mu \mathrm{S})$ & 697 & 7.4 & 30.80 & 45.10 & 83.27 & 79.50 & 7540.00 & 126527.0 & 355.70634 \\
\hline
\end{tabular}

Note: E.C. = electrical conductivity; details on the analytical techniques are referred on section 2.4.

Table C - Statistical estimates for the geochemical variables analyzed in the stream water and stream sediment samples of the State of Paraná Low-density Geochemical Survey (Licht 2001b).

\begin{tabular}{|c|c|c|c|c|c|c|c|c|c|}
\hline $\begin{array}{c}\text { Element } \\
\text { (unit) }\end{array}$ & Valid N & $\begin{array}{c}\text { Minimum } \\
\text { value }\end{array}$ & $1^{\text {st }}$ quartile & Median & Arithmetic mean & $3^{\text {rd }}$ quartile & $\begin{array}{c}\text { Maximum } \\
\text { value }\end{array}$ & $\begin{array}{c}\text { Variance } \\
\text { deviation }\end{array}$ \\
\hline $\mathrm{Cd}(\mathrm{ppm})$ & 690 & 0.1 & 0.1 & 0.1 & 0.111 & 0.1 & 4.4 & 0.0408 & 0.20199 \\
\hline
\end{tabular}




\begin{tabular}{|c|c|c|c|c|c|c|c|c|c|}
\hline $\mathrm{Pb}(\mathrm{ppm})$ & 690 & 1.0 & 8.0 & 14.0 & 18.59 & 20.0 & 580.0 & 1084.78 & 32.93600 \\
\hline $\mathrm{Co}(\mathrm{ppm})$ & 690 & 0.25 & 5.5 & 20.0 & 31.21 & 55.0 & 114.0 & 792.71 & 28.15511 \\
\hline $\mathrm{Cu}(\mathrm{ppm})$ & 690 & 0.25 & 11.0 & 66.5 & 114.48 & 200.0 & 610.0 & 14881.42 & 121.98943 \\
\hline $\mathrm{Cr}(\mathrm{ppm})$ & 690 & 0.5 & 12.0 & 35.5 & 62.25 & 100.0 & 400.0 & 4180.66 & 64.65802 \\
\hline $\mathrm{Li}(\mathrm{ppm})$ & 627 & 0.2 & 3.2 & 6.8 & 7.0 & 10.0 & 29.0 & 22.61 & 4.75500 \\
\hline $\mathrm{Mn}(\mathrm{ppm})$ & 696 & 2.8 & 265.0 & 954.5 & 1504.94 & 2350.0 & 9000.0 & 2389999.98 & 1545.96248 \\
\hline $\mathrm{Mo}(\mathrm{ppm})$ & 690 & 0.1 & 0.5 & 0.5 & 0.613 & 0.5 & 5.0 & 0.214 & 0.46260 \\
\hline $\mathrm{Ni}(\mathrm{ppm})$ & 690 & 0.25 & 4.0 & 15.0 & 21.01 & 32.0 & 470.0 & 675.73 & 25.99481 \\
\hline $\mathrm{V}(\mathrm{ppm})$ & 690 & 2.0 & 38.0 & 220.0 & 361.96 & 620.0 & 1460.0 & 127605.3 & 357.21884 \\
\hline $\mathrm{Zn}(\mathrm{ppm})$ & 690 & 1.0 & 24.0 & 76.0 & 89.55 & 142.0 & 840.0 & 6026.31 & 77.62931 \\
\hline $\mathrm{Fe}(\%)$ & 690 & 0.02 & 1.36 & 5.10 & 7.35 & 15.0 & 17.0 & 38.59 & 6.21208 \\
\hline
\end{tabular}

Note: details on the analytical techniques are referred on section 2.4.

Table D - Statistical estimates for the geochemical variables analyzed in the 39 GGRN sub-cells (composited from 696 stream sediment samples) of the State of Paraná (Licht 2001a).

\begin{tabular}{|c|c|c|c|c|c|c|c|c|c|}
\hline Element/oxide & Unit & $\begin{array}{l}\text { Minimum } \\
\text { value }\end{array}$ & $\begin{array}{c}1 \text { st } \\
\text { Quartile }\end{array}$ & Median & $\begin{array}{c}\text { Arithmetic } \\
\text { mean }\end{array}$ & $\begin{array}{c}\text { 3rd } \\
\text { Quartile }\end{array}$ & $\begin{array}{l}\text { Maximum } \\
\text { value }\end{array}$ & Variance & $\begin{array}{l}\text { Standard } \\
\text { deviation }\end{array}$ \\
\hline $\mathrm{Ag}$ & $\mathrm{ppb}$ & 31.00 & 53.00 & 62.00 & 62.487 & 70.00 & 94.00 & 219.362 & 14.811 \\
\hline $\mathrm{Al}_{2} \mathrm{O}_{3}$ & $\%$ & 0.94 & 6.98 & 12.29 & 10.893 & 14.43 & 20.35 & 26.577 & 5.155 \\
\hline As & $\mathrm{ppm}$ & 1.00 & 1.13 & 1.91 & 2.019 & 2.60 & 4.65 & 0.842 & 0.9173 \\
\hline $\mathrm{Au}$ & ppb & 0.00 & 1.44 & 2.26 & 2.992 & 3.90 & 14.56 & 8.027 & 2.833 \\
\hline $\mathrm{B}$ & $\mathrm{ppm}$ & 3.30 & 8.70 & 23.40 & 31.733 & 43.20 & 206.60 & 1358.016 & 36.851 \\
\hline $\mathrm{Ba}$ & $\mathrm{ppm}$ & 94.00 & 169.00 & 264.00 & 311.153 & 320.00 & 1064.00 & 50744.555 & 225.265 \\
\hline $\mathrm{Be}$ & ppm & 0.98 & 1.27 & 1.69 & 1.812 & 2.25 & 3.40 & 0.369 & 0.607 \\
\hline $\mathrm{Bi}$ & $\mathrm{ppm}$ & 0.05 & 0.10 & 0.14 & 0.137 & 0.16 & 0.31 & 0.003 & 0.058 \\
\hline $\mathrm{Br}$ & ppm & 1.00 & 2.90 & 6.10 & 6.287 & 9.40 & 16.50 & 16.748 & 4.092 \\
\hline $\mathrm{C}_{\text {org }}$ & $\mathrm{ppm}$ & 0.05 & 0.49 & 0.73 & 0.78 & 1.03 & 1.94 & 0.173 & 0.416 \\
\hline $\mathrm{CaO}$ & $\%$ & 0.14 & 0.34 & 0.68 & 0.689 & 0.96 & 1.47 & 0.160 & 0.400 \\
\hline $\mathrm{Cd}$ & $\mathrm{ppb}$ & 10.00 & 41.00 & 69.00 & 74.846 & 104.00 & 300.00 & 2600.870 & 50.998 \\
\hline $\mathrm{Ce}$ & $\mathrm{ppm}$ & 6.70 & 29.30 & 48.80 & 67.136 & 82.40 & 373.70 & 4256.929 & 65.245 \\
\hline $\mathrm{Cl}$ & ppm & 5.00 & 21.00 & 42.00 & 44.538 & 49.00 & 391.00 & 3550.887 & 59.589 \\
\hline $\mathrm{Co}$ & $\mathrm{ppm}$ & 1.70 & 11.60 & 43.00 & 63.754 & 118.70 & 172.20 & 3403.751 & 58.341 \\
\hline $\mathrm{Cr}$ & $\mathrm{ppm}$ & 14.00 & 39.00 & 78.00 & 92.641 & 134.00 & 213.00 & 3946.447 & 62.820 \\
\hline $\mathrm{Cs}$ & $\mathrm{ppm}$ & 1.00 & 2.50 & 4.10 & 4.767 & 7.30 & 10.40 & 7.691 & 2.773 \\
\hline $\mathrm{Cu}$ & ppm & 5.30 & 18.30 & 110.70 & 163.785 & 303.40 & 491.40 & 26050.273 & 161.401 \\
\hline Dy & $\mathrm{ppm}$ & 0.67 & 3.82 & 5.15 & 5.167 & 5.82 & 19.70 & 9.508 & 3.083 \\
\hline $\mathrm{Er}$ & $\mathrm{ppm}$ & 0.62 & 2.40 & 3.07 & 3.176 & 3.48 & 12.90 & 3.602 & 1.897 \\
\hline $\mathrm{Eu}$ & ppm & 0.10 & 0.92 & 1.33 & 1.311 & 1.79 & 3.10 & 0.441 & 0.664 \\
\hline $\mathrm{F}$ & ppm & 100.00 & 134.00 & 174.00 & 185.128 & 220.00 & 322.00 & 3392.536 & 58.245 \\
\hline $\mathrm{FeO}_{\text {total }}$ & $\%$ & 0.83 & 5.14 & 11.54 & 12.047 & 19.76 & 24.61 & 63.925 & 7.995 \\
\hline $\mathrm{Ga}$ & $\mathrm{ppm}$ & 3.50 & 10.20 & 18.60 & 19.338 & 29.20 & 38.40 & 112.303 & 10.597 \\
\hline $\mathrm{Gd}$ & $\mathrm{ppm}$ & 0.45 & 4.08 & 5.55 & 5.595 & 6.66 & 19.00 & 10.386 & 3.223 \\
\hline $\mathrm{Ge}$ & ppm & 0.70 & 0.83 & 0.87 & 0.923 & 0.96 & 1.46 & 0.028 & 0.168 \\
\hline $\mathrm{Hg}$ & $\mathrm{ppb}$ & 4.10 & 23.90 & 35.60 & 33.338 & 40.80 & 56.50 & 186.485 & 13.656 \\
\hline Ho & $\mathrm{ppm}$ & 0.18 & 0.83 & 1.09 & 1.109 & 1.23 & 4.38 & 0.435 & 0.659 \\
\hline I & ppm & 0.40 & 1.60 & 3.00 & 3.385 & 5.30 & 8.40 & 4.699 & 2.167 \\
\hline $\mathrm{K}_{2} \mathrm{O}$ & $\%$ & 0.12 & 0.28 & 0.40 & 0.695 & 0.90 & 3.98 & 0.539 & 0.734 \\
\hline $\mathrm{La}$ & $\mathrm{ppm}$ & 1.90 & 23.70 & 29.30 & 35.577 & 37.70 & 139.00 & 728.372 & 26.988 \\
\hline $\mathrm{Li}$ & $\mathrm{ppm}$ & 3.60 & 12.70 & 14.90 & 18.269 & 21.70 & 53.00 & 114.345 & 10.693 \\
\hline $\mathrm{Lu}$ & ppm & 0.16 & 0.42 & 0.47 & 0.531 & 0.55 & 2.09 & 0.092 & 0.304 \\
\hline $\mathrm{MgO}$ & $\%$ & 0.04 & 0.35 & 0.56 & 0.522 & 0.66 & 1.22 & 0.069 & 0.263 \\
\hline $\mathrm{Mn}$ & $\mathrm{ppm}$ & 161.00 & 578.00 & 1883.00 & 1761.846 & 2665.00 & 4755.00 & 1323584.976 & 1150.471 \\
\hline Mo & $\mathrm{ppm}$ & 0.30 & 0.60 & 0.86 & 0.890 & 1.14 & 1.61 & 0.120 & 0.346 \\
\hline $\mathrm{N}$ & $\%$ & 0.01 & 0.05 & 0.08 & 0.09 & 0.13 & 0.17 & 0.002 & 0.047 \\
\hline $\mathrm{Na}_{2} \mathrm{O}$ & $\%$ & 0.04 & 0.10 & 0.15 & 0.201 & 0.24 & 0.70 & 0.026 & 0.161 \\
\hline $\mathrm{Nb}$ & $\mathrm{ppm}$ & 4.70 & 18.40 & 42.50 & 39.620 & 53.50 & 82.20 & 462.147 & 21.497 \\
\hline $\mathrm{Nd}$ & $\mathrm{ppm}$ & 2.20 & 21.80 & 27.90 & 30.731 & 34.30 & 110.00 & 382.772 & 19.564 \\
\hline $\mathrm{Ni}$ & ppm & 4.40 & 13.30 & 31.20 & 39.931 & 59.40 & 108.10 & 942.597 & 30.702 \\
\hline $\mathrm{P}$ & ppm & 57.00 & 367.00 & 807.00 & 799.154 & 1210.00 & 1664.00 & 230284.081 & 479.879 \\
\hline $\mathrm{Pb}$ & $\mathrm{ppm}$ & 4.60 & 14.30 & 20.80 & 20.682 & 28.20 & 52.00 & 104.860 & 10.240 \\
\hline $\mathrm{Pd}$ & ppb & 0.00 & 0.23 & 1.12 & 2.593 & 5.19 & 11.73 & 8.523 & 2.919 \\
\hline $\operatorname{Pr}$ & ppm & 0.74 & 5.72 & 7.14 & 8.026 & 8.66 & 28.90 & 26.106 & 5.109 \\
\hline $\mathrm{Pt}$ & $\mathrm{ppb}$ & 0.00 & 0.62 & 1.12 & 3.297 & 5.38 & 14.01 & 15.706 & 3.963 \\
\hline $\mathrm{Rb}$ & $\mathrm{ppm}$ & 4.10 & 14.10 & 24.10 & 29.695 & 41.10 & 148.40 & 625.157 & 25.003 \\
\hline $\mathrm{S}$ & ppm & 0.01 & 0.01 & 0.02 & 0.023 & 0.03 & 0.05 & 0.0001 & 0.011 \\
\hline $\mathrm{Sb}$ & $\mathrm{ppm}$ & 0.12 & 0.23 & 0.35 & 0.329 & 0.41 & 0.60 & 0.013 & 0.116 \\
\hline $\mathrm{Sc}$ & $\mathrm{ppm}$ & 1.10 & 8.30 & 20.50 & 22.915 & 37.80 & 48.30 & 251.340 & 15.854 \\
\hline $\mathrm{Se}$ & $\mathrm{ppm}$ & 0.04 & 0.13 & 0.28 & 0.260 & 0.37 & 0.49 & 0.020 & 0.143 \\
\hline
\end{tabular}

Table D (Cont.) - Statistical estimates for the geochemical variables analyzed in the 39 GGRN sub-cells (composited from 696 stream sediment samples) of the State of Paraná (Licht 2001a).

\begin{tabular}{|c|c|c|c|c|c|c|c|c|c|}
\hline Element/oxide & Unit & $\begin{array}{c}\text { Minimum } \\
\text { value }\end{array}$ & $\begin{array}{c}\text { 1st } \\
\text { Quartile }\end{array}$ & Median & $\begin{array}{c}\text { Arithmetic } \\
\text { mean }\end{array}$ & $\begin{array}{c}\text { 3rd } \\
\text { Quartile }\end{array}$ & $\begin{array}{c}\text { Maximum } \\
\text { value }\end{array}$ & Variance & $\begin{array}{c}\text { Standard } \\
\text { deviation }\end{array}$ \\
\hline $\mathrm{SiO}_{2}$ & $\%$ & 30.89 & 41.19 & 57.36 & 59.945 & 79.63 & 90.86 & 431.891 & 20.782 \\
\hline
\end{tabular}




\begin{tabular}{|c|c|c|c|c|c|c|c|c|c|}
\hline $\mathrm{Sm}$ & $\mathrm{ppm}$ & 0.39 & 4.22 & 5.62 & 5.927 & 6.76 & 20.40 & 12.694 & 3.563 \\
\hline $\mathrm{Sn}$ & $\mathrm{ppm}$ & 0.59 & 2.06 & 2.56 & 2.820 & 3.16 & 7.63 & 2.244 & 1.498 \\
\hline $\mathrm{Sr}$ & $\mathrm{ppm}$ & 11.00 & 31.00 & 45.00 & 54.589 & 64.00 & 200.00 & 1679.248 & 40.978 \\
\hline $\mathrm{Tb}$ & $\mathrm{ppm}$ & 0.14 & 0.73 & 0.92 & 0.946 & 1.07 & 3.35 & 0.280 & 0.529 \\
\hline $\mathrm{Te}$ & $\mathrm{ppm}$ & 10.00 & 16.00 & 24.00 & 27.077 & 35.00 & 69.00 & 181.862 & 13.485 \\
\hline $\mathrm{Th}$ & $\mathrm{ppm}$ & 0.00 & 7.70 & 10.20 & 13.231 & 12.50 & 74.40 & 169.664 & 13.025 \\
\hline $\mathrm{Ti}$ & $\mathrm{ppm}$ & 0.22 & 1.31 & 2.74 & 2.827 & 4.26 & 6.17 & 2.814 & 1.677 \\
\hline $\mathrm{Tl}$ & $\mathrm{ppm}$ & 0.04 & 0.13 & 0.22 & 0.288 & 0.37 & 1.12 & 0.049 & 0.221 \\
\hline $\mathrm{Tm}$ & $\mathrm{ppm}$ & 0.13 & 0.39 & 0.47 & 0.514 & 0.53 & 2.09 & 0.093 & 0.305 \\
\hline $\mathrm{U}$ & $\mathrm{ppm}$ & 0.50 & 0.80 & 1.30 & 1.797 & 2.00 & 10.00 & 2.956 & 1.719 \\
\hline $\mathrm{V}$ & $\mathrm{ppm}$ & 33.00 & 120.00 & 491.00 & 576.538 & 1004.00 & 1509.00 & 233063.045 & 482.766 \\
\hline $\mathrm{W}$ & $\mathrm{ppm}$ & 0.32 & 0.42 & 0.70 & 0.807 & 0.98 & 2.60 & 0.242 & 0.492 \\
\hline $\mathrm{Y}$ & $\mathrm{ppm}$ & 4.60 & 20.80 & 25.70 & 26.513 & 29.10 & 116.00 & 293.282 & 17.125 \\
\hline $\mathrm{Yb}$ & $\mathrm{ppm}$ & 0.88 & 2.59 & 3.08 & 3.297 & 3.45 & 13.40 & 3.715 \\
\hline $\mathrm{Zn}$ & $\mathrm{ppm}$ & 4.10 & 38.20 & 121.80 & 128.151 & 192.20 & 280.70 & 8316.486 & 91.195 \\
\hline $\mathrm{Zr}$ & $\mathrm{ppm}$ & 280.00 & 444.00 & 662.00 & 948.667 & 1002.00 & 4175.00 & 777354.281 & 881.677 \\
\hline
\end{tabular}

Note: details on the analytical techniques are referred on section 2.6.

Table E - Statistical estimates for the geochemical variables determined in the 41 GGRN sub-cells (composited from 309 soil - B horizon samples) of the State of Paraná (Licht \& Plawiak 2005).

\begin{tabular}{|c|c|c|c|c|c|c|c|c|c|}
\hline Element/oxide & Unit & $\begin{array}{c}\text { Minimum } \\
\text { value }\end{array}$ & $\begin{array}{c}1^{\text {st }} \\
\text { quartile }\end{array}$ & Median & $\begin{array}{l}\text { Arithmetic } \\
\text { mean }\end{array}$ & $\begin{array}{c}3^{\text {rd }} \\
\text { quartile }\end{array}$ & $\begin{array}{l}\text { Maximum } \\
\text { value }\end{array}$ & Variance & $\begin{array}{l}\text { Standard } \\
\text { deviation }\end{array}$ \\
\hline $\mathrm{Ag}$ & $\mathrm{ppb}$ & 38.00 & 47.00 & 54.00 & 54.93 & 61.00 & 78.00 & 93.590 & 9.674 \\
\hline $\mathrm{Al}_{2} \mathrm{O}_{3}$ & $\%$ & 17.64 & 21.75 & 23.03 & 23.28 & 24.94 & 29.48 & 6.250 & 2.500 \\
\hline As & ppm & 2.40 & 4.40 & 5.50 & 7.25 & 9.80 & 29.40 & 22.361 & 4.729 \\
\hline $\mathrm{Au}$ & $\mathrm{ppb}$ & 0.52 & 1.27 & 2.08 & 2.71 & 3.99 & 6.64 & 2.887 & 1.699 \\
\hline $\mathrm{B}$ & $\mathrm{ppm}$ & 6.00 & 11.00 & 24.00 & 27.37 & 36.00 & 99.00 & 409.144 & 20.227 \\
\hline $\mathrm{Ba}$ & $\mathrm{ppm}$ & 43.00 & 107.00 & 147.00 & 171.07 & 193.00 & 502.00 & 10556.828 & 102.746 \\
\hline $\mathrm{Be}$ & $\mathrm{ppm}$ & 0.39 & 1.25 & 1.61 & 1.51 & 1.82 & 2.74 & 0.243 & 0.493 \\
\hline $\mathrm{Bi}$ & $\mathrm{ppm}$ & 0.13 & 0.20 & 0.28 & 0.30 & 0.34 & 0.57 & 0.014 & 0.120 \\
\hline $\mathrm{Br}$ & ppm & 1.00 & 7.30 & 10.70 & 11.32 & 13.90 & 25.60 & 32.188 & 5.673 \\
\hline $\mathrm{C}$ & $\%$ & 0.29 & 0.75 & 0.97 & 0.96 & 1.20 & 1.60 & 0.088 & 0.297 \\
\hline $\mathrm{C}_{\text {org }}$ & $\%$ & 0.14 & 0.53 & 0.77 & 0.76 & 1.00 & 1.43 & 0.074 & 0.272 \\
\hline $\mathrm{CaO}$ & $\%$ & 0.05 & 0.07 & 0.12 & 0.13 & 0.18 & 0.35 & 0.006 & 0.074 \\
\hline $\mathrm{Cd}$ & $\mathrm{ppb}$ & 48.00 & 124.00 & 181.00 & 181.79 & 221.00 & 457.00 & 7258.646 & 85.198 \\
\hline $\mathrm{Ce}$ & ppm & 41.00 & 74.00 & 89.00 & 96.40 & 113.00 & 220.00 & 1431.102 & 37.830 \\
\hline $\mathrm{Cl}$ & $\mathrm{ppm}$ & 22.00 & 36.00 & 41.00 & 41.74 & 45.00 & 60.00 & 83.052 & 9.113 \\
\hline Co & ppm & 3.90 & 6.70 & 18.90 & 23.84 & 41.80 & 61.90 & 344.789 & 18.568 \\
\hline $\mathrm{Cr}$ & $\mathrm{ppm}$ & 43.00 & 69.00 & 87.00 & 105.42 & 139.00 & 230.00 & 2451.821 & 49.516 \\
\hline Cs & $\mathrm{ppm}$ & 2.10 & 3.10 & 4.80 & 5.19 & 6.20 & 19.40 & 8.521 & 2.919 \\
\hline $\mathrm{Cu}$ & $\mathrm{ppm}$ & 20.40 & 40.20 & 117.20 & 141.72 & 267.90 & 318.80 & 12109.980 & 110.045 \\
\hline Dy & $\mathrm{ppm}$ & 2.21 & 3.91 & 5.86 & 5.80 & 6.73 & 12.76 & 5.397 & 2.323 \\
\hline Er & $\mathrm{ppm}$ & 1.18 & 2.19 & 3.13 & 3.18 & 3.78 & 6.27 & 1.239 & 1.113 \\
\hline $\mathrm{Eu}$ & $\mathrm{ppm}$ & 0.53 & 1.10 & 1.54 & 1.63 & 1.98 & 3.60 & 0.523 & 0.724 \\
\hline F & $\mathrm{ppm}$ & 99.00 & 202.00 & 269.00 & 272.33 & 325.00 & 631.00 & 12127.415 & $\begin{array}{l}110.125 \\
\end{array}$ \\
\hline $\mathrm{FeO}_{\text {total }}$ & $\%$ & 4.96 & 8.75 & 16.87 & 15.05 & 21.22 & 26.34 & 47.344 & 6.881 \\
\hline $\mathrm{Ga}$ & $\mathrm{ppm}$ & 11.80 & 26.20 & 31.40 & 30.74 & 36.50 & 46.50 & 76.587 & 8.751 \\
\hline $\mathrm{Gd}$ & $\mathrm{ppm}$ & 2.21 & 3.89 & 5.49 & 5.69 & 6.59 & 12.31 & 5.125 & 2.264 \\
\hline $\mathrm{Ge}$ & $\mathrm{ppm}$ & 0.97 & 1.56 & 2.02 & 2.02 & 2.47 & 3.14 & 0.285 & 0.534 \\
\hline $\mathrm{Hf}$ & $\mathrm{ppm}$ & 8.90 & 11.20 & 12.90 & 14.13 & 15.90 & 27.30 & 17.798 & 4.219 \\
\hline $\mathrm{Hg}$ & $\mathrm{ppb}$ & 13.40 & 40.20 & 52.50 & 60.90 & 71.40 & 160.70 & 1051.154 & 32.422 \\
\hline Ho & $\mathrm{ppm}$ & 0.43 & 0.77 & 1.06 & 1.08 & 1.28 & 2.18 & 0.149 & 0.387 \\
\hline I & $\mathrm{ppm}$ & 3.33 & 8.22 & 12.84 & 12.83 & 16.14 & 27.84 & 32.523 & 5.703 \\
\hline In & $\mathrm{ppm}$ & 0.04 & 0.09 & 0.12 & 0.11 & 0.13 & 0.19 & 0.001 & 0.032 \\
\hline $\mathrm{K}_{2} \mathrm{O}$ & $\%$ & 0.07 & 0.12 & 0.22 & 0.44 & 0.72 & 1.91 & 0.209 & 0.457 \\
\hline $\mathrm{La}$ & $\mathrm{ppm}$ & 16.00 & 28.00 & 35.00 & 37.95 & 44.00 & 72.00 & 193.664 & 13.916 \\
\hline $\mathrm{Li}$ & $\mathrm{ppm}$ & 9.60 & 17.00 & 24.70 & 25.67 & 33.30 & 54.20 & 118.003 & 10.863 \\
\hline $\mathrm{Lu}$ & ppm & 0.23 & 0.39 & 0.53 & 0.54 & 0.68 & 1.01 & 0.030 & 0.174 \\
\hline $\mathrm{MgO}$ & $\%$ & 0.15 & 0.28 & 0.39 & 0.39 & 0.49 & 0.80 & 0.020 & 0.141 \\
\hline $\mathrm{Mn}$ & $\mathrm{ppm}$ & 135.00 & 315.00 & 538.00 & 736.84 & 1094.00 & 1980.00 & 226981.997 & 476.426 \\
\hline Mo & $\mathrm{ppm}$ & 0.73 & 1.34 & 1.64 & 1.68 & 1.90 & 3.17 & 0.260 & 0.510 \\
\hline $\mathrm{N}$ & $\mathrm{ppm}$ & 204.00 & 518.00 & 686.00 & 702.1628 & 882.00 & 1106.00 & 54211.14 & 232.833 \\
\hline $\mathrm{Na}_{2} \mathrm{O}$ & $\%$ & 0.02 & 0.03 & 0.04 & 0.06 & 0.06 & 0.31 & 0.003 & 0.052 \\
\hline $\mathrm{Nb}$ & $\mathrm{ppm}$ & 14.00 & 22.00 & 27.00 & 28.16 & 33.00 & 63.00 & 109.235 & 10.452 \\
\hline $\mathrm{Nd}$ & $\mathrm{ppm}$ & 14.00 & 23.00 & 34.00 & 33.86 & 39.00 & 73.00 & 176.028 & 13.268 \\
\hline $\mathrm{Ni}$ & $\mathrm{ppm}$ & 8.00 & 17.00 & 26.00 & 34.16 & 53.00 & 87.00 & 422.092 & 20.545 \\
\hline $\mathrm{P}$ & $\mathrm{ppm}$ & 266.00 & 452.00 & 593.00 & 627.53 & 850.00 & 1179.00 & 53384.207 & 231.050 \\
\hline $\mathrm{Pb}$ & $\mathrm{ppm}$ & 15.00 & 19.00 & 22.00 & 23.21 & 26.00 & 45.00 & 36.979 & 6.081 \\
\hline
\end{tabular}

Table E (cont.) - Statistical estimates for the geochemical variables determined in the 41 GGRN sub-cells (composited from 309 soil - B horizon samples) of the State of Paraná (Licht \& Plawiak 2005).

\begin{tabular}{|c|c|c|c|c|c|c|c|c|c|}
\hline Element/oxide & Unit & $\begin{array}{c}\text { Minimum } \\
\text { value }\end{array}$ & $\begin{array}{c}1^{\text {st }} \\
\text { quartile }\end{array}$ & Median & $\begin{array}{c}\text { Arithmetic } \\
\text { mean }\end{array}$ & $\begin{array}{c}3^{\text {rd }} \\
\text { quartile }\end{array}$ & $\begin{array}{c}\text { Maximum } \\
\text { value }\end{array}$ & Variance & $\begin{array}{c}\text { Standard } \\
\text { deviation }\end{array}$ \\
\hline $\mathrm{Pd}$ & $\mathrm{ppb}$ & 0.54 & 1.25 & 3.23 & 5.55 & 9.97 & 15.91 & 24.546 & 4.954 \\
\hline
\end{tabular}




\begin{tabular}{|c|c|c|c|c|c|c|c|c|c|}
\hline $\operatorname{Pr}$ & ppm & 4.20 & 6.50 & 8.40 & 9.09 & 10.70 & 19.30 & 11.962 & 3.459 \\
\hline $\mathrm{Pt}$ & $\mathrm{ppb}$ & 0.32 & 0.70 & 2.37 & 4.80 & 7.92 & 19.92 & 25.036 & 5.004 \\
\hline $\mathrm{Rb}$ & ppm & 7.00 & 12.00 & 19.00 & 28.16 & 36.00 & 124.00 & 574.711 & 23.973 \\
\hline $\mathrm{S}$ & ppm & 111.00 & 151.00 & 207.00 & 222.30 & 274.00 & 451.00 & 7076.835 & 84.124 \\
\hline $\mathrm{Sb}$ & $\mathrm{ppm}$ & 0.26 & 0.48 & 0.60 & 0.74 & 0.98 & 1.81 & 0.133 & 0.365 \\
\hline $\mathrm{Sc}$ & $\mathrm{ppm}$ & 7.30 & 16.70 & 33.90 & 31.04 & 46.50 & 57.10 & 246.125 & 15.688 \\
\hline $\mathrm{Se}$ & ppm & 0.16 & 0.30 & 0.47 & 0.53 & 0.56 & 2.84 & 0.185 & 0.430 \\
\hline $\mathrm{SiO}_{2}$ & $\%$ & 30.41 & 36.75 & 41.29 & 43.88 & 51.28 & 62.59 & 88.208 & 9.392 \\
\hline $\mathrm{Sm}$ & ppm & 2.73 & 4.70 & 6.79 & 6.94 & 8.05 & 15.34 & 7.685 & 2.772 \\
\hline $\mathrm{Sn}$ & ppm & 1.50 & 2.50 & 3.20 & 3.38 & 3.92 & 8.99 & 2.093 & 1.447 \\
\hline $\mathrm{Sr}$ & $\mathrm{ppm}$ & 12.00 & 19.00 & 25.00 & 36.95 & 48.00 & 126.00 & 777.474 & 27.883 \\
\hline $\mathrm{Ta}$ & ppm & 0.88 & 1.80 & 2.30 & 2.46 & 2.86 & 6.00 & 1.054 & 1.027 \\
\hline $\mathrm{Tb}$ & $\mathrm{ppm}$ & 0.37 & 0.68 & 0.97 & 0.99 & 1.16 & 2.05 & 0.146 & 0.383 \\
\hline $\mathrm{Th}$ & ppm & 4.10 & 8.60 & 11.20 & 13.30 & 18.50 & 28.30 & 31.677 & 5.628 \\
\hline $\mathrm{Ti}$ & $\mathrm{ppm}$ & 6156.00 & 8929.00 & 16602.00 & 15726.47 & 21407.00 & 32176.00 & 52039234.4 & 7213.822 \\
\hline $\mathrm{Tl}$ & $\mathrm{ppm}$ & 0.15 & 0.27 & 0.36 & 0.40 & 0.51 & 1.42 & 0.045 & 0.213 \\
\hline $\mathrm{Tm}$ & ppm & 0.21 & 0.37 & 0.53 & 0.53 & 0.65 & 1.08 & 0.032 & 0.179 \\
\hline $\mathrm{U}$ & ppm & 1.00 & 2.00 & 2.90 & 3.02 & 4.00 & 7.60 & 1.669 & 1.292 \\
\hline $\mathrm{V}$ & ppm & 81.00 & 129.00 & 360.00 & 370.37 & 570.00 & 856.00 & 60563.668 & 246.097 \\
\hline $\mathrm{W}$ & $\mathrm{ppm}$ & 0.62 & 1.02 & 1.44 & 1.57 & 2.01 & 3.40 & 0.408 & 0.639 \\
\hline $\mathrm{Y}$ & ppm & 9.60 & 22.80 & 27.50 & 27.64 & 33.70 & 50.30 & 67.572 & 8.220 \\
\hline $\mathrm{Yb}$ & $\mathrm{ppm}$ & 1.35 & 2.34 & 3.27 & 3.35 & 4.09 & 6.45 & 1.199 & 1.095 \\
\hline $\mathrm{Zn}$ & $\mathrm{ppm}$ & 24.00 & 47.00 & 77.00 & 75.26 & 103.00 & 124.00 & 1003.719 & 31.682 \\
\hline $\mathrm{Zr}$ & ppm & 299.00 & 376.00 & 431.00 & 455.67 & 519.00 & 776.00 & 10926.987 & 104.532 \\
\hline
\end{tabular}

Note: details on the analytical techniques are referred on section 2.6. 